\title{
Bienen, Wespen und ihre Gegenspieler in Kaffee-Anbausystemen auf Sulawesi: Bestäubungserfolg, Interaktionen, Habitatbewertung
}

\author{
Dissertation \\ zur Erlangung des Doktorgrades \\ der Fakultät für Agrarwissenschaften \\ der Georg-August-Universität Göttingen
}

vorgelegt von

Alexandra-Maria Klein

geboren in Göttingen

Göttingen, Mai 2003 
1. Referent: Prof. Dr. Teja Tscharntke

2. Korreferent: Prof. Dr. Matthias Schäfer

Tag der mündlichen Prüfung: 22.05.2003 
Die einzelnen Themenabschnitte der Dissertationsschrift sind in den folgenden Zeitschriften veröffentlicht oder eingereicht:

Klein, A.M., Steffan-Dewenter, I. \& TscharntKe, T. (2003) Bee pollination and fruit set of Coffea arabica and C. canephora (Rubiaceae). American Journal of Botany 90, 153 157.

KLein, A.M., Steffan-Dewenter, I. \& TscharntKe, T. (2003) Fruit set of highland coffee increases with the diversity of pollinating bees. The Proceedings of the Royal Society of London, Series B 270, 955-961.

Klein, A.M., Steffan-Dewenter, I. \& Tscharntke, T. (in press) Flower visitation and fruit set of Coffea canephora in relation to local and regional agroforestry management. Journal of Applied Ecology.

Klein, A.M., Steffan-Dewenter, I. \& TscharntKe, T. (submitted) Effects of forest distance on trophic interactions and diversity of trap-nesting bees, wasps, and their enemies in tropical agroforestry systems. Oecologia.

Klein, A.M., StefFan-Dewenter, I. \& Tscharntke, T. (submitted) Foraging trip duration and reproductive success of megachilid bees, eumenid wasps, and pompilid wasps in tropical agroforestry systems. Journal of Animal Ecology. 


\section{Inhaltsverzeichnis}

1 Bienen, WeSPEN UND IHRE GEGENSPIELER IN KAFFEE-ANBAUSYSTEMEN AUF SULAWESI: BESTÄUBUNGSERFOLG, INTERAKTIONEN, HABITATBEWERTUNG. EIN ÜBERBLICK.

$\begin{array}{lr}\text { Einleitung } & 6\end{array}$

$\begin{array}{lr}\text { Fragestellungen } & 8\end{array}$

$\begin{array}{ll}\text { Ergebnisse } & 14\end{array}$

$\begin{array}{ll}\text { Schlussfolgerungen } & 17\end{array}$

2 BEE POLLINATION AND FRUIT SET OF COFFEA ARABICA AND C. CANEPHORA (RUBIACEAE)

$\begin{array}{lr}\text { Introduction } & 19\end{array}$

$\begin{array}{lr}\text { Materials and methods } & \mathbf{2 0}\end{array}$

Study species - Flower morphology - Study area - Pollination experiments and fruit set - Flower-visiting bees - Statistics

Results $\quad 24$

C. canephora - C. arabica - Flower visitation

$\begin{array}{ll}\text { Discussion } & \mathbf{2 6}\end{array}$

3 FRUIT SET OF HIGHLAND COFFEE INCREASES WITH THE DIVERSITY OF POLLINATING BEES

$\begin{array}{ll}\text { Introduction } & \mathbf{3 0}\end{array}$

Materials and methods

Study area and experimental sites - Flower-visiting bees and fruit set - Statistics

$\begin{array}{ll}\text { Results } & \mathbf{3 4}\end{array}$

$\begin{array}{ll}\text { Discussion } & 38\end{array}$

4 FLOWER VISITATION AND FRUIT SET OF COFFEA CANEPHORA IN RELATION TO LOCAL AND REGIONAL AGROFORESTRY MANAGEMENT

$\begin{array}{ll}\text { Introduction } & 43\end{array}$

Materials and methods $\quad 44$

Study region and study sites - Flower-visiting bees and fruit set of

C. canephora - Statistics

Results 
Flower visitation - Fruit set - Pollination efficiency

Discussion

5 EFFECTS OF FOREST DISTANCE ON TROPHIC INTERACTIONS AND DIVERSITY OF TRAP-NESTING BEES, WASPS, AND THEIR NATURAL ENEMIES IN TROPICAL AGROFORESTRY SYSTEMS

Introduction $\quad \mathbf{5 4}$

Materials and methods $\quad 56$

Study region and agroforestry systems - Trap nests - Statistics

Results $\quad \mathbf{5 8}$

Community structure - Effects of local and regional habitat parameters

Discussion $\quad 63$

Isolation of agroforestry systems from natural forest - Habitat management -

Differences between dry and rainy season

6 FORAGING TRIP DURATION AND REPRODUCTIVE SUCCESS OF MEGACHILID BEES, EUMENID WASPS, AND POMPILID WASPS IN TROPICAL AGROFORESTRY SYSTEMS $\begin{array}{ll}\text { Introduction } & 69\end{array}$

$\begin{array}{ll}\text { Materials and methods } & 71\end{array}$

Study region and study sites - Trap nests - Foraging trip duration - Statistics

Results

Trap-nests - Foraging time: 1. Heriades (Michenerella) sp. aff. fulvescens

(Apidaea - Rhynchium haemorrhoidale umeroatrum (Eumenidae) - Auplopus levicarinatus (Pompilidae)

Discussion

$\begin{array}{lr}\text { Zusammenfassung } & \mathbf{8 1}\end{array}$

$\begin{array}{lr}\text { Summary } & \mathbf{8 3}\end{array}$

$\begin{array}{ll}\text { Literaturverzeichnis } & 85\end{array}$

$\begin{array}{lr}\text { Publikationen der Autorin } & 98\end{array}$

$\begin{array}{ll}\text { Danksagung } & 100\end{array}$

$\begin{array}{ll}\text { Lebenslauf } & 102\end{array}$ 


\section{Einleitung}

Die anhaltende Zerstörung der sehr artenreichen tropischen Regenwälder und ihr Wechsel zu Landnutzungssystemen gilt als eine der Hauptursachen für den fortschreitenden, weltweiten Rückgang der Biodiversität (Watt et al. 1997; Laurance \& Bierregaard 1997; Sala et al. 2000). Im Hinblick auf den Verlust an Biodiversität ist der Wechsel vom Regenwald über die traditionelle Landwirtschaft bis zur intensiven Monokultur in tropischen Ländern bisher wenig untersucht worden (Pimentel et al. 1992; Power \& Flecker 1996; Perfecto et al. 1997; Watt et al. 1997; Lenne \& Wood 1999; Fox et al. 2000). Allerdings ist allgemein bekannt, dass die traditionelle Landnutzung im Vergleich zu der konventionellen Landnutzung sehr artenreich ist (Pimentel et al. 1992; Perfecto \& Snelling 1995; Perfecto et al. 1996; Fujisaka et al. 1998; Vandermeer et al. 1998; Moguel \& Toledo 1999; Rice \& Greenberg 2000; Siebert 2002). Mit zunehmender Intensivierung der Landwirtschaft können Arten wegfallen, andere Arten wiederum gefördert werden (Klein et al. 2002a,b). Der Artenaustausch oder Ausfall in den funktionellen Gruppen, wie den Bestäubern, Prädatoren und Parasitoide, kann wichtige Funktionen für ökologische Prozesse gefährden (Klein et al. 2002a,b; Kremen et al. 2003). Experimente zur Bestäubungsleistung in einem Waldgradienten mit zunehmender anthropogener Beeinflussung führten Ghazoul et al. (1998) an einer Dipterocarpaceae in Thailand durch. Diese Ergebnisse zeigten, dass der Bestäubungserfolg mit zunehmender anthropogener Nutzung abnimmt. Für die Tropen gibt es allerdings kaum Studien, die die Veränderungen von ökologischen Funktionen mit zunehmender Intensivierung der Landwirtschaft zeigen.

Nicht nur die Intensivierung der Landwirtschaft beeinflusst diese ökologischen Funktionen. Mit der Umwandlung des Regenwaldes zu Agrarökosystemen mit vereinzelten Waldrelikten verändert sich die Landschaftsstruktur erheblich. Die ursprünglichen Lebensgemeinschaften und deren Funktionen für ökologische Prozesse (Bestäubung, Prädation und Parasitierung) werden dadurch ebenfalls beeinflusst (Kareiva 1987; Naeem et al. 1994; Didham et al. 1996; Marino \& Landis 1996; Kunin 1997; Roland \& Taylor 1997; Vitousek et al. 1997; Menalled et al. 1999; Huston 1999; Thies \& Tscharntke 1999; Ricketts 2001; Tilman et al. 2001; Perfecto \& Vandermeer 2002; Steffan-Dewenter 2002; Tscharntke et al. 2002a,b). Bienen und Wespen eignen sich besonders für eine differenzierte Landschaftsbewertung, weil sie als sensible Indikatoren für Umweltveränderungen und Lebensraumunterschiede gelten (Westrich 1989; Tscharnkte et al. 1998). Die mutualistische Pflanze-Bestäuber-Beziehung ist eine Ökosystemfunktion, die durch den Biodiversitätsverlust 
beeinträchtigt werden kann (Rathcke \& Jules 1993; Rathcke \& Jules 1999; Renner 1998). Durch eine reduzierte Bestäubungsleistung kann es in isolierten Pflanzenpopulationen zu einem verminderten Fruchtansatz kommen (Steffan-Dewenter \& Tscharntke 1999; Donaldson et al. 2002). Aizen und Feinsinger (1994a) zeigten z.B. in Argentinien, dass mit zunehmender Modifikation des Waldes die Abundanz und Diversität von einheimischen Wildbienen als Blütenbesucher abnahmen, die Zahl der Blütenbesuche insgesamt aber durch höhere Abundanzen der Honigbienen an den Blüten ausgeglichen worden ist. In den modifizierten Waldfragmenten kam es zu einer Abnahme in der durchschnittlichen Anzahl von Pollenschläuchen und somit $\mathrm{zu}$ einem geringeren Bestäubungserfolg durch Honigbienen (Aizen \& Feinsinger 1994b).

Weil mindestens $30 \%$ der menschlichen Nahrung von bienenbestäubten Pflanzen stammen (Mc Gregor 1976), kann durch die Abnahme der Bestäubungsleistung die Qualität und Quantität dieser Nahrungsmittel gefährdet werden (Allen-Wardell et al. 1998). Kremen et al. (2003) zeigten in ökologisch angebauten Wassermelonenplantagen in Kalifornien, dass die Wildbienenlebensgemeinschaften einen optimalen Bestäubungserfolg erzielten, wenn diese in der Nähe von großen Gebieten von Eichenwäldern gepflanzt wurden. In Plantagen, die sich weit entfernt von einem natürlichen Habitat befanden und/oder konventionell bewirtschaftet wurden, war die Bestäubungsleistung reduziert, was zu Ertragseinbußen führen könnte.

Es gibt nur wenige Untersuchungen, die Veränderungen in der Struktur der Lebensgemeinschaften analysieren, die durch die Störung und Isolation der natürlichen Habitate und den Interaktionen zwischen Arten auf höherer trophischer Ebene hervorgerufen wurden (Kruess \& Tscharntke 1994; Harrison \& Bruna 1999; Holt et al. 1999; Tscharntke \& Kruess 1999, Steffan-Dewenter 2002). Arten auf höheren trophischen Ebenen reagieren sehr sensibel auf Umweltveränderungen (Holt et al. 1999). Der Verlust von Arten auf höheren trophischen Ebenen und mutualistischen Arten kann eine Aussterbekaskade anderer Organismen verursachen (Greenwood 1987; LaSalle \& Gauld 1993).

In der vorliegenden Studie wurden 24 Agroforstsysteme miteinander verglichen, die von Naturwaldbäumen oder gepflanzten Leguminosen unterschiedlich intensiv beschattet werden und sich in der unmittelbaren Nähe oder weiter entfernt vom Regenwaldrand befinden. Dabei wurde die Bedeutung der lokalen und regionalen Landnutzung auf die InsektenLebensgemeinschaft in Nisthilfen und die Pflanze-Bestäuber-Lebensgemeinschaft am Kaffee untersucht.

In dem ersten Teil der vorliegenden Studie wurden die Artenzahl und Häufigkeit von solitären und sozialen Bienen und ihre Bestäubungsleistung an zwei Kaffeearten untersucht. 
In einer zweiten Langzeitstudie wurden Artenzahl und Häufigkeit von Bienen, Wespen und ihre Interaktionen mit ihren natürlichen Gegenspielern untersucht.

In einem zusätzlichen Experiment wurde die Sammelflugzeit (Zeit, die ein Individuum braucht, um Proviant für die Larven in die Nester einzutragen) von drei nisthilfenbewohnenden Arten gemessen, um die Ressourcenverfügbarkeit und damit die Qualität der Agroforstsysteme für Bienen und Wespen zu zeigen.

\section{Folgende Fragestellungen standen im Vordergrund:}

\section{Kaffee}

- Wie sieht die Bestäubungsbiologie des Hoch- und Tieflandkaffees aus (Selbst-, Windund Fremdbestäubungsgrad)?

* Unterscheiden sich die blütenbesuchenden Bienenlebensgemeinschaften am Tief- und Hochlandkaffee?

* Wird die Diversität und Abundanz der blütenbesuchenden Bienengemeinschaften am Hoch- und Tieflandkaffee durch die Entfernung vom Regenwaldrand und die Beschattung und Diversität der Pflanzen in den Agroforstsystemen beeinflusst?

* Ist der Fruchtansatz des Hochland- und Tieflandkaffees von der Diversität und Abundanz der blütenbesuchenden Bienen abhängig?

* Sind die solitären und/oder die sozialen Bienenarten die effizienteren Bestäuber am Hochland- und Tieflandkaffee?

\section{Nisthilfen}

- Nehmen die nisthilfenbewohnenden Artenzahlen von Bienen, Wespen und ihren Gegenspielern mit zunehmender Entfernung vom Regenwaldrand ab?

* Sind die höheren trophischen Ebenen (Parasitoide) in den Nisthilfen stärker von der Isolation betroffen als ihre Wirte?

* Beinflussen lokale Habitatfaktoren im Agroforstsystem wie Lichtintensität und Pflanzendiversität die Nisthilfenlebensgemeinschaft?

* Gibt es signifikante Unterschiede in der Häufigkeit der Bienen und Wespen zwischen der Regen- und der Trockenzeit?

* Sind die Sammelflugzeiten einer nisthilfenbewohnenden Biene und zweier Wespen vom Ressourcenangebot der Agroforstsysteme und der Nähe zum Regenwald abhängig? 
Spiegelt die Nistplatzwahl der Nisthilfenbewohner die Ressourcenverfügbarkeit wider?

\section{Lebensräume und Organismen der Untersuchung}

\section{Agroforstsysteme}

In Zentral-Sulawesi wird durch menschlichen Einfluss zunehmend der ursprüngliche Regenwald durch ein Mosaik aus kleinen Dörfern, traditioneller Land- und Forstwirtschaft und übergebliebenen Waldfragmenten ersetzt. Eine weitverbreitete traditionelle Landnutzungsform in tropischen Ländern ist das Agroforstsystem. Dies zeichnet sich durch sogenannte Schattenbäume aus, die über mehreren Kulturpflanzenarten wachsen. Diese Systeme werden sowohl land- als auch forstwirtschaftlich genutzt und sind aus ökologischer und ökonomischer Sicht wertvoller als eine Monokultur (Nair 1993, 1998). Somit sichern Agroforstsysteme vielen Kleinbauern nicht nur ihr Einkommen, sondern liefern zusätzlich vielfältige Nahrungsmittel, Heilpflanzen, Brenn- und Baumaterial und Futter für ihre Haustiere (Herzog 1994; Escalante 1995; Lenne \& Wood 1999; Fox et al. 2000; Soto-Pinto et al. 2000; Peeters et al. 2003). Innerhalb der Agroforstsysteme kommt es zu unterschiedlich intensiven Nutzungsformen. Ein Agroforstsystem kann relativ einfach strukturiert sein, indem eine Schattenbaumart über mindestens zwei Kulturpflanzenarten wächst. Andererseits kann ein Agroforstsystem aus einer Vielzahl von übergelassenen Primärwaldbaumarten, angepflanzten Schattenbäumen mit vielen unterschiedlichen Kulturpflanzen und einer hohen Diversität an Bodenbedeckern bestehen. Letzteres kann dem ursprünglichen Regenwald in seiner Struktur sehr ähnlich sein (Abb.1). 

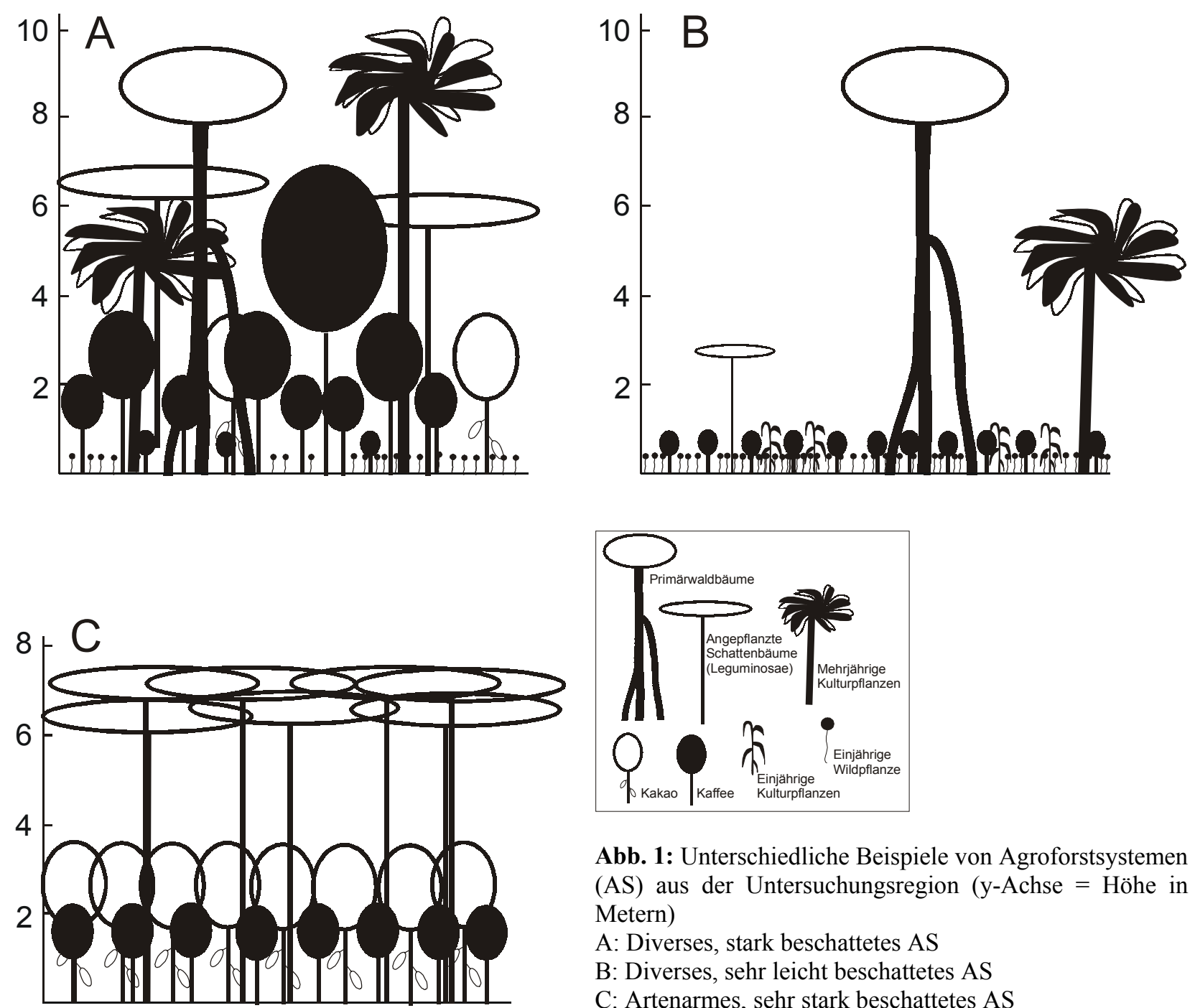

Abb. 1: Unterschiedliche Beispiele von Agroforstsystemen (AS) aus der Untersuchungsregion (y-Achse = Höhe in Metern)

A: Diverses, stark beschattetes AS
B: Diverses, sehr leicht beschattetes AS
C: Artenarmes, sehr stark beschattetes AS

\section{Die Organismen}

Kaffee ist nach Erdöl das zweitwichtigste Exportgut aus tropischen Ländern. In einigen Entwicklungsländern bringt der Kaffeemarkt sogar den größten Devisenanteil (Rice \& Ward 1997). Momentan ist der Devisenanteil durch Kaffee geringer, da Kaffee in den letzten Jahren durch Überproduktion einen starken Preisverfall erlitten hat. Allerdings wird erwartet, dass die Kaffeepreise sich in den nächsten Jahren wieder erholen werden. Somit wird Kaffee langfristig ein sehr wichtiges Exportgut bleiben.

Kaffee gehört $\mathrm{zu}$ der in den Tropen weitverbreiteten Familie der Rubiacae (Rötegewächse). Außerhalb der Tropen gibt es nur sehr wenige und ausschließlich annuelle, krautige Rötegewächse, wie z.B. Waldmeister. Kaffee ist unter Kultur meist ein niedriger Busch, der wildwachsend aber eine Höhe von mehreren Metern erreichen kann. An der Weltproduktion für Kaffee sind zwei wichtige Kaffeearten beteiligt. Der Hochlandkaffee Coffea arabica L. liefert 70\% des Weltmarktanteils. Der Tieflandkaffee Coffea canephora 
Pierre ex Froehner, syn. Coffea robusta, liefert 30 \%. Morphologisch lassen sich die beiden Arten leicht anhand der Blatt- und Blütengröße unterscheiden. C. canephora besitzt die größeren Blätter und Blüten, von denen ein sehr starker Duft ausgeht.

Kaffee blüht mehrmals im Jahr. Normalerweise wird eine große Kaffeeblüte im ganzen Bestand durch heftige Regenfälle ausgelöst. Während der Blüte kommen zahlreiche Insekten, um sich Nektar und Pollen von den Blüten zu holen. Der größte Anteil der Blütenbesucher sind Bienen, deshalb stehen die Bienen im Mittelpunkt dieser Arbeit. Die Bienen werden in zwei Gruppen aufgeteilt:

1) Die sozialen, in Staaten lebenden Bienen, dazu gehören die Honigbienen der Gattung Apis und die stachellosen Bienen der Gattung Trigona. Die sozialen Bienen sind artenarm aber sehr individuenreich.

2) Die solitären, nicht in Staaten lebenden Bienen sind sehr artenreich, aber die verschiedenen Arten zeigen meist geringe Dichten (Abb. 2).

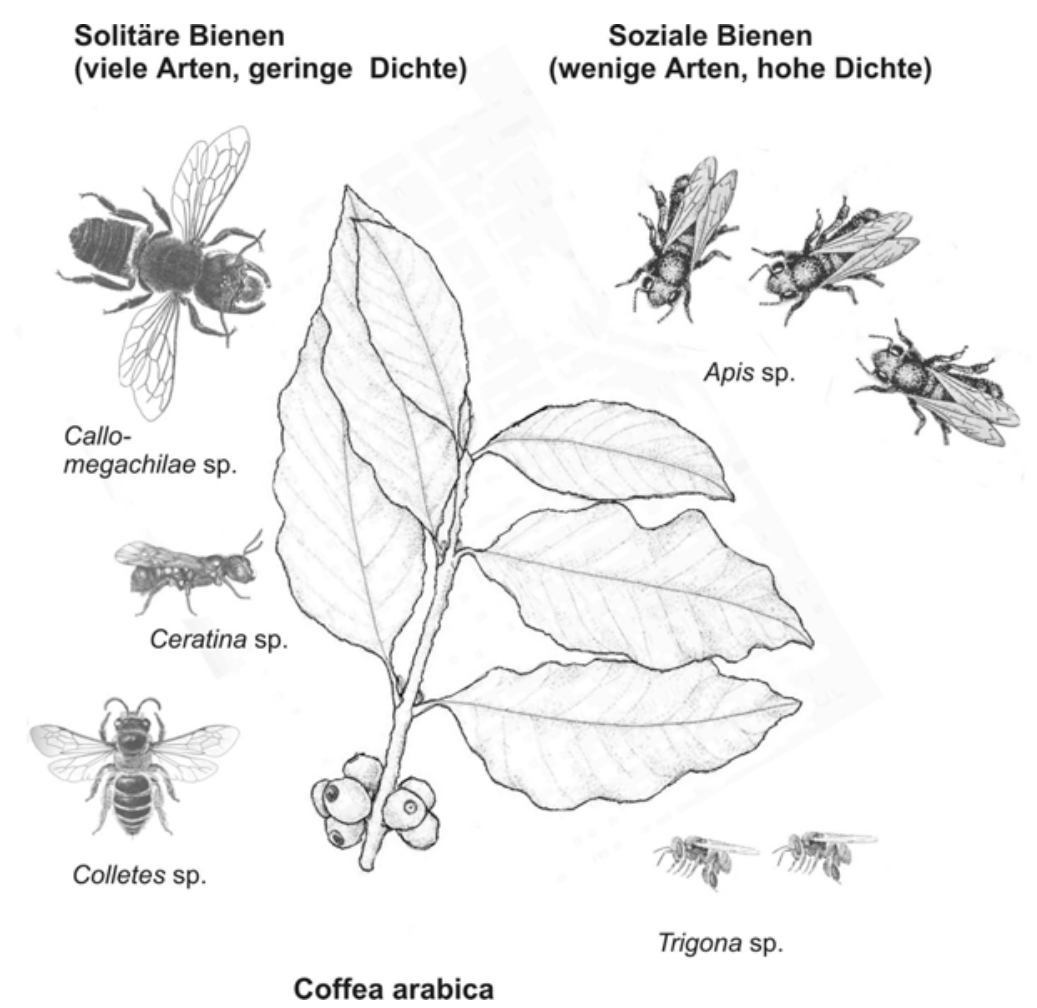

Abb. 2: Die Bienenlebensgemeinschaft am Kaffee in Zentral-Sulawesi

C. canephora gilt als selbststerile, fremdbestäubende Art (Willmer \& Stone 1989; Rehm \& Espig 1995). In der älteren Literatur wird diese Kaffeeart hauptsächlich als windbestäubend beschrieben (Van Hall 1938; Ferwerda 1948; Purseglove 1968; Crane \& Walker 1984), die Bestäubung durch Insekten soll von geringer Bedeutung sein (Purseglove 1968). Gegenläufig 
zu diesen Ergebnissen zeigten Willmer und Stone (1989) am Tieflandkaffee in PapuaNeuguinea, dass Windbestäubung und die Bestäubung durch Ameisen irrelevant waren. Zum Bestäubungserfolg führten lediglich die Bienen, wobei eine solitäre Bienenart (Creightonella frontalis) der effizientere Bestäuber im Vergleich $\mathrm{zu}$ der eingeführten Europäischen Honigbiene (Apis mellifera) war. Auch in Zentral-Sulawesi scheinen solitäre Bienen zum Bestäubungserfolg einen wesentlichen Beitrag zu leisten (Klein et al. 2000a). Free (1993) erwähnt ebenfalls eine Ertragssteigerung durch die Erhöhung der Bestäubungsleistung am Kaffee. C. arabica ist eine selbstbestäubende Art (Rehm \& Espig 1991; Free 1993). Obwohl diese Art selbstfertil ist, konnte gezeigt werden, dass eine hohe Honigbienendichte beim Besuch der Blüten den Fruchtansatz erhöht (Raw \& Free 1977; Reddy et al. 1988; Manrique \& Thimann 2002; Roubik 2002a,b).

Eine standardisierte Methode zur Erfassung solitärer Bienen und Wespen ist die Ausbringung von Nisthilfen (Krombein 1967; Jayasingh \& Freeman 1980; Roubik 1989; Gathmann et al. 1994; Roubik 1995; Gathmann 1999; Gathmann \& Tscharntke 1999; Oku \& Nishida 1999). Einige solitäre Bienen, z.B. aus den Familien Megachilidae und Anthophoridae, nisten in hohlen Stängeln (Roubik 1995) und können somit durch diese Methode erfasst werden. Weiter werden solitäre Wespen aus den Familien Eumenidae, Sphecidae und Pompilidae erfasst. Zu den Gegenspielern gehören Prädatoren wie z.B. Vögel, Spinnen, räuberische Insekten und Parasitoide aus verschiedenen Insektenfamilien, die vorwiegend mit den Nisthilfen erfasst werden (Abb. 3). Die Exposition standardisierter Nisthilfen aus Schilf und dem Japanischen Staudenknöterich erlaubt gleichermaßen Aussagen zur Artenvielfalt und Interaktionen (ökologische Funktionen), so dass sie für Fragen der Bioindikation gut geeignet sind. Die Analyse der Lebensgemeinschaften in Nisthilfen erlaubt auch die Quantifizierung von Räuber-Beute- bzw. Wirt-Parasitoid-Beziehungen. Durch die Quantifizierung der Sammelflugzeiten bei der Verproviantierung der Nester von Bienen und Wespen können Rückschlüsse auf die Habitatqualität gezogen werden (Gathmann 1998; Gathmann \& Tscharntke 2002). Faltenwespen sind Prädatoren, die phytophage Insekten in ihre Nester eintragen. Sie können somit auch als natürliche Gegenspieler von Schädlingen Bedeutung erlangen und durch Nisthilfen in strukturarmen Lebensräumen gefördert werden (Harris 1994). 
Interaktionen Trophische Ebene
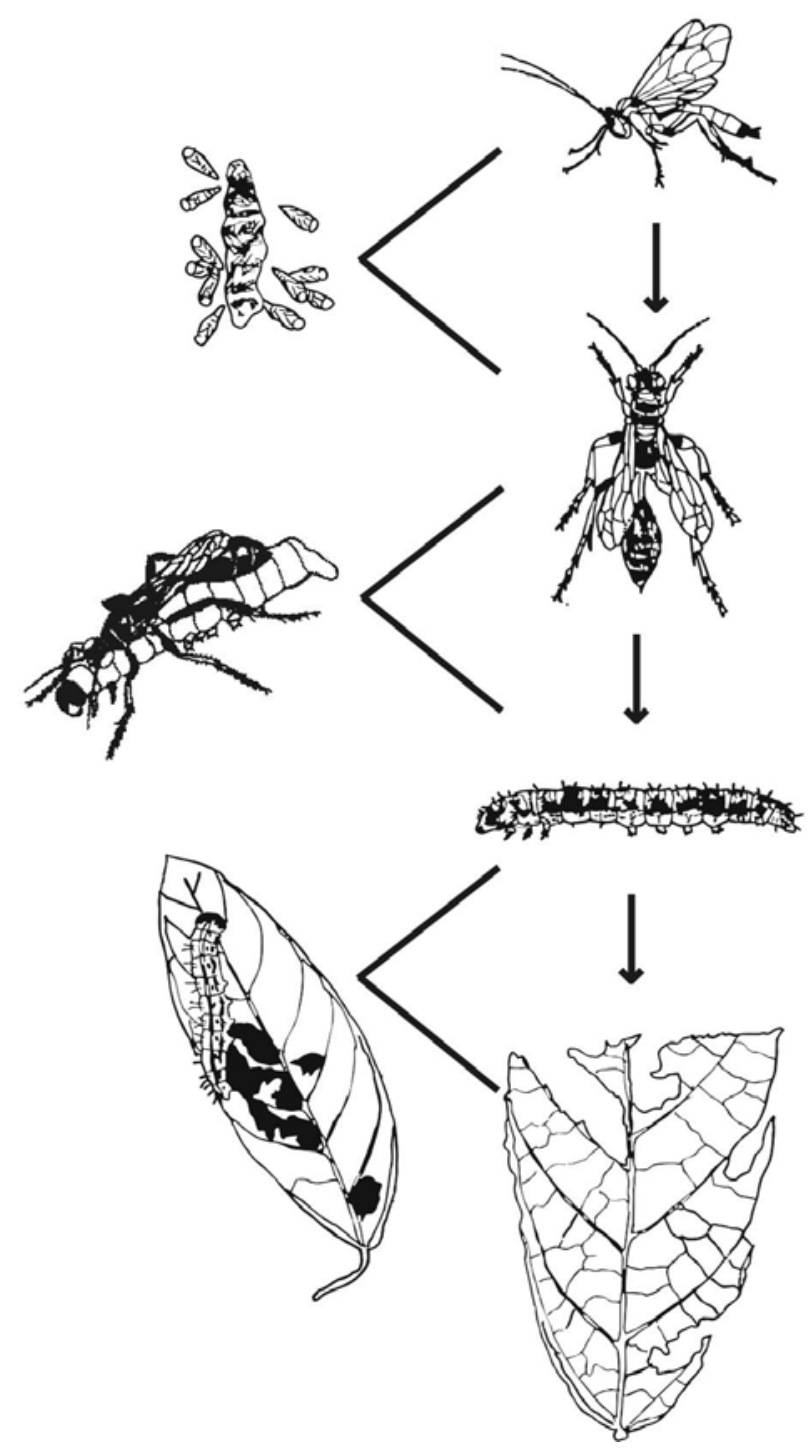

Abb. 3: Trophische Interaktionen in Nisthilfen: Eine parasitische Wespe parasitiert die Larve einer anderen, räuberischen Wespe, die eine herbivore Larve als Futter für die Aufzucht ihrer Nachkommen in die Nisthilfe einträgt 


\section{Ergebnisse}

\section{Kaffeebestäubung}

Sowohl die selbstfertile Kaffeeart (Hochlandkaffee, Coffea arabica) als auch die selbststerile Kaffeeart (Tieflandkaffee, Coffea canephora) zeigten den höchsten mittleren Fruchtansatz, wenn Insekten und Wind nicht ausgeschlossen wurden (offene Bestäubung) oder wenn eine manuelle Kreuzbestäubung mit Fremdpollen durchgeführt wurde. Windbestäubung führte zu einem verminderten Fruchtansatz von 16\% gegenüber der offenen Bestäubung von $C$. canephora, und $12,3 \%$ bei C. arabica. Die drei Selbstbestäubungsexperimente führten zu einem sehr geringen Fruchtansatz von ca. 10\% bei der selbststerilen Art, aber zwischen 48\% und $60 \%$ bei der selbstfertilen Art. Diese Ergebnisse zeigen eindeutig, dass C. arabica zu einem mittleren Fruchterfolg durch Selbstbestäubung gelangte, aber durch Bestäubungskräfte, die zu einer Kreuzbestäubung führten, zusätzlich bis zu 30\% mehr Fruchtansatz erreichte. $C$. canephora dagegen war auf Fremdeinflüsse, die zu einer Kreuzbestäubung führten, angewiesen (Kapitel 2).

Ausgehend von diesen Ergebnissen wurde der Einfluss des lokalen Agroforstmanagements und der Isolation der Agroforstsysteme vom Regenwald auf die Artenzahl und Häufigkeit der Bestäuberlebensgemeinschaft und den Bestäubungserfolg für beide Kaffeearten untersucht. Die Untersuchungen am selbstfertilen Hochlandkaffee $(C$. arabica) wurden in allen 24 Flächen durchgeführt. Insgesamt besuchten 2.038 Bienenindividuen und 29 Bienenarten C. arabica (Tab. 1, Kapitel 2). Der Fruchtansatz stand im engen Zusammenhang mit der Diversität der blütenbesuchenden Bienen, aber nicht mit ihrer Häufigkeit. Drei Arten führten zu ca. 60\% Fruchtansatz, im Gegensatz zu 20 Arten die zu ca. 90\% Fruchtansatz führten.

In einem weiteren Experiment wurden einzelne Bienenindividuen beim Besuch einer Kaffeeblüte beobachtet. Damit sollte gezeigt werden, welche Bienenarten die Pflanzen des Hochlandkaffees optimal bestäuben. Es zeigte sich, dass die seltener vorkommenden solitären Bienenarten zu einem höheren Fruchtansatz führten als die häufigen sozialen Bienenarten. Obwohl die hohe Individuendichte der sozialen Bienen sicher für einen Großteil des Fruchtansatzes verantwortlich war, zeigten diese Beobachtungen, dass die solitären Arten auf Einzelindividuenebene die effizienteren Bestäuber für den Hochlandkaffee waren. Die Diversität der sozialen und der solitären Bienen zeigten für beide Gruppen getrennt einen signifikanten Zusammenhang mit dem Fruchtansatz. Die Diversität der blütenbesuchenden Bienen am Hochlandkaffee wurde durch zwei wichtige Habitatparameter beeinflusst, die 
Hinweise auf die spezifischen Nestanforderungen der sozialen gegenüber den solitären Arten gaben: a) Die Diversität der sozialen Arten nahm mit zunehmender Waldrandentfernung signifikant ab; b) Die Diversität der solitären Arten nahm mit zunehmender Lichtintensität in den Flächen zu (Kapitel 3).

Die Untersuchungen am selbststerilen Tieflandkaffee (C. canephora) wurden nur in 15 Flächen durchgeführt, weil diese Art in neun Flächen entweder gar nicht oder nur mit ein bis zwei Pflanzen vorkam, die zur Untersuchungszeit nicht blühten. Insgesamt besuchten 2.269 Bienenindividuen und 33 Bienenarten $C$. canephora. Berücksichtigt man die geringere Flächenanzahl wurde $C$. canephora von fast doppelt so vielen Bienenindividuen besucht wie C. arabica (Tab. 1, Abb. 2). Der Fruchtansatz stand in engem Zusammenhang mit der Diversität und der Häufigkeit der blütenbesuchenden Bienen. Nach der Auftrennung in die Gruppen soziale und solitäre Bienenarten zeigte sich, dass der Fruchtansatz mit zunehmenden sozialen Arten und Individuen signifikant zunahm, aber nicht mit den solitären Arten und Individuen. Beim Blütenbesuch einzelner Individuen an C. canephora zeigte sich, dass auch bei dieser Kaffeeart die solitären Bienen im Einzelfall effizienter bestäubten als die sozialen Bienen. Im Zusammenhang mit den Habitatparametern konnte auch für diese Art gezeigt werden, dass die sozialen Bienenarten mit zunehmender Waldentfernung abnahmen und die solitären Arten mit zunehmender Lichtintensität zunahmen.

\section{Bienen, Wespen und ihre Gegenspieler in Nisthilfen}

Innerhalb von 15 Monaten wurden 13.617 Brutzellen von Bienen und Wespen in 240 Nisthilfen angelegt. In den Brutzellen befanden sich 14 Bienen- und Wespenarten und 25 Gegenspielerarten, die bis auf einen Prädator ausschließlich den Parasitoiden angehörten. Mehr als 50\% der Brutzellen wurden von einer Wegwespe angelegt. Die meisten Arten wurden nur in sehr wenigen Brutzellen gefunden.

Die Diversität der Bienen und Wespen nahm mit zunehmender Isolation vom Regenwald $\mathrm{ab}$ und mit zunehmender Lichtintensität in den Agroforstsystemen zu. Die Diversität der Gegenspieler und die Parasitierungsrate waren ausschließlich von der Isolation vom Regenwald beeinflusst. Diese höchste trophische Ebene innerhalb der Nisthilfen war stärker durch die Isolation vom Regenwald beeinflusst als ihre Wirte. Innerhalb einer Entfernung von 500m zum Regenwald nahmen die Artenzahlen der Gegenspieler von acht auf fünf $a b$, und die Parasitierungsrate sank ebenfalls von $12 \%$ auf $4 \%$. Die Dichte der Nisthilfenbewohner variierte stark zwischen den einzelnen Monaten. Die Dichte der Wespen 
zeigte einen signifikanten Unterschied zwischen der Regen- und Trockenzeit, wohingegen die Bienendichte keinen Saisonalitätseffekt aufwies.

Die Sammelflugzeiten der drei am häufigsten vorkommenden nisthilfenbewohnenden Arten waren signifikant positiv mit der Verfügbarkeit von Ressourcen korreliert, die sie für die Aufzucht ihrer Nachkommen brauchen. Dazu zählten 1) eine Biene, die Blütenpollen und Nektar als Futter für ihre Larven in die Nisthilfen eintrug, 2) eine Wegwespe, die räuberische Spinnen für ihre Larven eintrug, und 3) eine Faltenwespe, die kakaoschädliche Raupen als Larvenfutter in die Nisthilfen eintrug. Die Anzahl der angelegten Brutzellen war nur bei einer Art mit der Sammelflugzeit signifikant korreliert, bei der Biene marginal signifikant. Die Anzahl der angelegten Brutzellen pro Art war mit der Lichtintensität in gleicher Weise korreliert wie die Sammelflugzeit. Die Brutzellenanzahl der Faltenwespe, aber nicht ihre Sammelflugzeit, korrelierte mit der Entfernung zum Regenwald. 


\section{Schlussfolgerungen}

Die Untersuchungen zur Bestäubungsbiologie am Hoch- und Tieflandkaffee zeigen, dass blütenbesuchende Bienen eine wichtige ökologische Funktion erfüllen. Diese ,freie' Leistung ist nicht nur aus ökologischer Sicht sehr wertvoll. Sie kann auch von wichtiger ökonomischer Bedeutung für die Kaffeefarmer sein.

Meist, und gerade in den Tropen, steht die Diversität in engem Zusammenhang mit der Häufigkeit der Arten. Durch die hohe Interkorrelation ist es kaum möglich, eindeutig festzustellen, ob die Häufigkeit oder die Diversität die ökologische Funktion beeinflusst. Der signifikante Zusammenhang zwischen der Bienendiversität und dem Fruchtansatz und der nicht vorhandene Zusammenhang mit der Häufigkeit der Bienen und dem Fruchtansatz für Pflanzen von C. arabica zeigt eindeutig, dass eine artenreiche Bienenlebensgemeinschaft wichtig für den Bestäubungserfolg ist, während wenige Bienenarten mit einer hohen Individuenzahl keinen optimalen Fruchtansatz sichern können. Somit liefern diese Untersuchungen einen wichtigen Beitrag $\mathrm{zu}$ der allgemeinen Diskussion über den Zusammenhang zwischen Artenvielfalt und ökologischen Funktionen.

Die zunehmende Entfernung zum Regenwaldrand beinflusste negativ: a) die sozialen Bienen, b) die Bienen und Wespen in den Nisthilfen, darunter einen Prädator für kakaoschädliche Raupen, c) und sehr stark die höchste trophische Ebene in den Nisthilfen, die Parasitoide. Solitäre Bienen und einige nisthilfenbewohnende Arten wurden mit zunehmender Lichtintensität und Pflanzendiversität positiv beeinflusst.

Die Nistplatzwahl korrelierte nicht zwingend mit der Ressourcenverfügbarkeit. Im Regenwald gibt es mehr Nistplätze für stängelnistende Bienen und Wespen als in Landnutzungsystemen. Dagegen ist das Nahrungsangebot in den Agroforstsystemen höher. Damit kommt es zu einem ,trade off' zwischen der Verfügbarkeit von Larvenfutter und Nistplätzen. Somit können sich einige Arten nur optimal reproduzieren, wenn verschiedenen Habitattypen (offene Landschaften und Regenwald) in ihrem Aktionsradius vorkommen, die in ihrer Gesamtheit alle benötigten Ressourcen abdecken.

Die Teilexperimente in dieser Arbeit führen $\mathrm{zu}$ folgenden allgemeinen Schlussfogerungen:

1) Auf regionaler Ebene sollten der noch intakte Regenwald und seine Relikte hohe Schutzpriorität bekommen. Durch die Nähe des Regenwaldes werden ,freie' ökologische Leistungen wie Bestäubung, Prädation und Parasitierung und der damit verbundene ökonomische Wert der traditionellen Agroforstsysteme gesichert. 
2) Auf lokaler Ebene beeinflusst als Hauptfaktor eine $\mathrm{zu}$ starke Beschattung einige ökologische Funktionen negativ: a) Reduzierte Bestäubungsleistung, verursacht durch den Verlust von solitären Beinenarten am Kaffee; b) Reduzierte biologische Schädlingsbekämpfung, verursacht durch eine geringere Prädatorendichte (Wespe nutzt kakaoschädigende Raupen als Larvenproviant).

Im Detail bedeutet das für ein gezieltes lokales Management, dass eine rechtzeitige Auflichtung der Agroforstsysteme erforderlich ist, um ein optimales Mikroklima, ein reichhaltiges Blütenangebot, um genügend Nektar und Pollen für Bienen, Wespen und ihre natürlichen Gegenspieler zu liefern, und Nistmöglichkeiten für solitäre Bienen und Wespen zu schaffen. 


\title{
2 BEE POLLINATION AND FRUIT SET OF COFFEA ARABICA AND C. CANEPHORA (RUbiaceAe)
}

\begin{abstract}
Self-sterile Coffea canephora and self-fertile C. arabica are important cash crops in many tropical countries. We examined the relative importance of insect, wind, and spontaneous self-pollination and the degree of self-fertility of these two coffee species in 24 agroforestry coffee fields in Indonesia. In both species, open pollination and cross pollination by hand led to the highest fruit set. Wind pollination (including self-pollination) led to $16 \%$ lower fruit set than open pollination in C. canephora and to $12.3 \%$ lower fruit set in C. arabica. Selfpollinated flowers and unmanipulated controls achieved an extremely low fruit set of $10 \%$ or less in the self-sterile species, and of $60 \%$ and $48 \%$, respectively in the self-fertile species. These results constitute experimental evidence that cross pollination by bees causes a significant increase in fruit set of not only the self-sterile, but also the self-fertile coffee species. The practical implication is that coffee yield may be improved by managing fields for increased flower visitation by bees.
\end{abstract}

Keywords: agroforestry, Coffea, Indonesia, plant-pollinator interactions, Sulawesi, sustainable agriculture, Rubiaceae.

\section{Introduction}

Fruit set of most plants depends on successful pollination by wind or animals, but herbivory, nutrient availability, and microclimatic conditions may also be important (Eriksson \& Ehrlén 1992; Turnbull et al. 2000). Bawa (1990) estimated that 89 - 99\% of all flowering plant species in tropical lowland rainforest are pollinated by animals, and bees are the most important pollinators (Roubik 1995; Renner 1998). Further, one-third of the total human diet in tropical countries is derived from insect-pollinated plants (Crane \& Walker 1983), and even in Europe, many crops depend on insect, especially bee, pollination (Corbet et al. 1991; Delaplane \& Mayer 2000). However, only a few crops are totally dependent on animal pollination and only few clear examples of low crop yield resulting from pollinator limitation have been described (Richards 2001). Despite their role as dominant pollen vectors, studies 
specific to bees in tropical Asia are rare, in contrast to the neotropics (Bawa et al. 1985; Roubik 1993).

In this paper, we experimentally examined the pollination systems of the lowland coffee (Coffea canephora Pierre ex Froehner, syn. Coffea robusta) and the highland coffee (Coffea arabica L.), and additionally observed the community of flower-visiting bees in 24 Indonesian coffee fields. We focused on the following questions:

1. What is the relative importance of cross pollination and self-pollination for fruit set in the two coffee species?

2. Does wind pollination lead to pollen limitation in comparison with pollination by insects?

3. Do the flower-visiting bee communities differ between the two coffee species?

To our knowledge, this is the first comparative study of pollination mechanism and the relative importance of wild bee communities for pollination and fruit set of C. canephora and C. arabica.

\section{Materials and methods}

\section{Study species}

The lowland coffee (Coffea canephora, syn. Coffea robusta) and the highland coffee (Coffea arabica) are two widespread species. C. canephora, a self-sterile, diploid species, is reported to be primarily wind pollinated, but is also expected to benefit from bees for effective outcrossing and fruit set (Le Pelley 1973; Crane \& Walker 1983; Willmer \& Stone 1989). Coffea canephora prefers low-altitude habitats, growing in sites where the more widespread Coffea arabica will not thrive. C. arabica is reported as a self-fertile, tetraploid species (Crane \& Walker 1983; Reddy et al. 1988; Smith et al. 1992; Free 1993). However, Raw and Free (1977) showed that caged honeybees (Apis mellifera L.) may almost double the yield of mature fruits in comparison to spontaneous self-pollination, and fruit retention also seems to be enhanced by outcrossing (Reddy et al. 1988; Free 1993; Roubik 2002). Bees frequently visit coffee during flowering (McDonald 1930; Nogueira-Neto et al. 1959; Raw \& Free 1977; Willmer \& Stone 1989; Klein et al. 2002a).

\section{Flower morphology}

Flower morphology is similar in both species, although the flowers of C. canephora are bigger and there are more flowers in the axils of leaves, on average 8 - 20 flowers per axil for 
C. canephora and 2 - 12 for C. arabica (A.M. Klein, personal observations; Free 1993). The flowers of both species have a five-segmented calyx and five white petals the lower half of which are fused into a cylindrical, elongated corolla tube. There are five stamens with long anthers and short filaments inserted into the corolla, a long thin style with a two-branched stigma, and an inferior ovary of two chambers each containing one ovule. The stigma is receptive when a flower opens at dawn and the anthers dehisce soon afterwards. The disc surrounding the base of the style secretes nectar (Free 1993).

\section{Study area}

The study was conducted from November 2000 to March 2001 in Central Sulawesi (Indonesia), at the margin of the Lore-Lindu National Park, $100 \mathrm{~km}$ northeast from the city of Palu, in the villages of Wuasa, Watumaeta, Alitupu, and Kaduwaa (1000 - 1200 m above sea level). We chose 24 different agroforestry coffee fields, which differed with respect to shade and vegetation. While C. arabica grew in all 24 fields, C. canephora was planted in only 15 fields.

\section{Pollination experiments and fruit set}

To examine the reproductive systems of $C$. canephora and $C$. arabica, we carried out six pollination experiments on open and bagged branches bearing dense and mature flower buds. For each of the six treatments we selected six different branches on each of four different coffee shrubs, and replicated this in all 24 fields (96 branches for each of the six experimental treatments resulting in altogether 576 branches) for C. arabica, and in 15 fields (60 branches for each treatment resulting in altogether 360 branches) for C. canephora. The six pollination treatments were as follows:

1. Open pollination. All insects had access to flowers (insect pollination), but wind pollination was also possible;

2. Wind pollination and spontaneous selfing were possible. Insects were excluded by coarse mesh gauze;

3. Cross pollination (between-plant pollination), hand pollination with pollen of several other plants;

4. Self pollination (within-plant pollination), hand pollination with pollen of the same plant, but from other flowers;

5. Self pollination, hand pollination with pollen of the same flower; 
6. Control (no pollination by external vectors), bagged flowers. Pollination by insects and wind was excluded, thereby testing for possible spontaneous self-pollination (autogamy).

To manipulate wind pollination we bagged branches with cotton mesh gauze with 0.8 $1.0 \mathrm{~mm}$ openings. For hand-pollination experiments very fine nylon mesh gauze $(10 \mu \mathrm{m})$ was used to avoid wind pollination, following Willmer and Stone (1989). We put sticky glue on the branch beneath the bagged flowers to eliminate crawling insects, especially ants. The bags were put in place 1 - 6 ds before flowering. Flower numbers of the observed bagged and open branches were counted. One mesh bag included 6-12 flowers for C. arabica and $10-21$ flowers for C. canephora. Thus we sampled about 864 flowers in each of the six pollination experiments for C. arabica (on average nine flowers on each of four branches selected in each of the 24 fields) and about 900 flowers in each of the six pollination experiments for $C$. canephora (on average 15 flowers on each of four branches selected in each of the 15 fields). Coffee started flowering usually 3 - 4 ds after substantial rainfall, and synchronously (all branches had open flowers at the same time) within individual plants. The flowering period finished after three days in C. canephora, whereas C. arabica had flowering periods of up to $7 \mathrm{ds}$. In the hand-pollination experiments, pollen was transferred to stigmas with a brush on the first day of flower opening. Five weeks after the end of the flowering period, bags were removed from flowers and the number of green fruits per branch was counted for each treatment. 


\section{Flower-visiting bees}

Abundance and species richness of flower visitors to the coffee bushes were observed from the end of December 2000 to the beginning of January 2001, in which period a substantial flush of flowers occurred. We observed flower visitors in each coffee field three times at three sequent days for 25 min on sunny days between 0900 and 1400. Only flower-visiting bees are included in this study, because other insects, such as butterflies and beetles, were extremely rare. After each 25-min observation period, bees were caught by sweep netting for another 5 min, for species identification in the laboratory. Social bees were identified with the help of a collection from Dr. Gard Otis, University of Guelph, Canada. Solitary bees were identified by Dr. Donald B. Baker, Hope Entomological Collections, Oxford University Museum of Natural History, UK.

\section{Statistics}

Statistical analyses of the data was performed using 'Statgraphics plus for windows 3.0' (Manugistics 1997). When necessary, logarithmic or square root-transformed variables were used to achieve a normal distribution. To compare the fruit set we used a multifactor analyses of variance with three variables (coffee fields, each coffee shrub observed, and the six pollination treatments). Fruit set did not differ between coffee fields $(F=0.98, p=0.478$ for C. canephora, $F=0.72, p=0.827$ for $C$. arabica $)$ or coffee shrubs $(F=0.76, p=0.511$ for $C$. canephora, $F=0.37, p=0.773$ for $C$. arabica) but between pollination treatments. Therefore, only effects of pollination treatments are shown in the results section. We used the Scheffé test to separate significantly different groups (Sokal \& Rohlf 1995). To compare the means of species and individual numbers between C. canephora and C. arabica we used the paired ttest. To estimate the total bee species richness for each coffee field, we used the estimator ACE (Abundance-based Coverage Estimator of species richness) with Estimate S, Version 5 (Colwell 1997), which allows calculating species saturation curves in dependence on sample size. 


\section{Results}

\section{C. canephora}

Fruit set for C. canephora was $78.1 \%$ in open pollination and $83.8 \%$ when flowers were handpollinated with pollen of another plant (Fig. 1A). There were no significant differences between hand pollination with pollen of another plant and open pollination, but wind pollination plus autogamy resulted in a significantly reduced $62.3 \%$ fruit set. Accordingly, bee pollination caused a $15.8 \%$ increase in fruit set, compared to wind pollination plus autogamy. Geitonogamous (within-plant) pollination resulted in $10.9 \%$ fruit set, autogamous (manual within-flower) pollination in $8.9 \%$ fruit set, and the control (insect and wind pollination excluded, so only autogamy was possible) in $8.7 \%$ fruit set. The latter three treatments showed no significant differences. Cross pollination by hand resulted in a $75.2 \%$ higher fruit set than in the control, and open pollination in a $69.4 \%$ higher fruit set than the control (Fig. 1A).

\section{C. arabica}

The self-fertile C. arabica showed $75.2 \%$ fruit set in open pollination and $75 \%$ in manually cross-pollinated flowers (Fig. 1B). Wind pollination plus autogamy resulted in a significantly lower fruit set of $62.9 \%$, so bee pollination accounted for a $12.3 \%$ increase in fruit set. Geitonogamy resulted in $57.5 \%$, and manual pollination within flowers in $62.4 \%$ fruit set. Within these three treatments no significant differences were found, but fruit set of the control (autogamy, 47.9\%) was significantly lower than all other treatments in C. arabica. We found $27 \%$ more fruit set in open pollination or cross pollination by hand as compared to the control (Fig. 1B). The comparison of both figures shows that differences between wind pollination (plus autogamy) and the control (autogamy) is much higher in C. canephora (53.6\%) than in C. arabica $(16 \%)$. 
A Coffea canephora

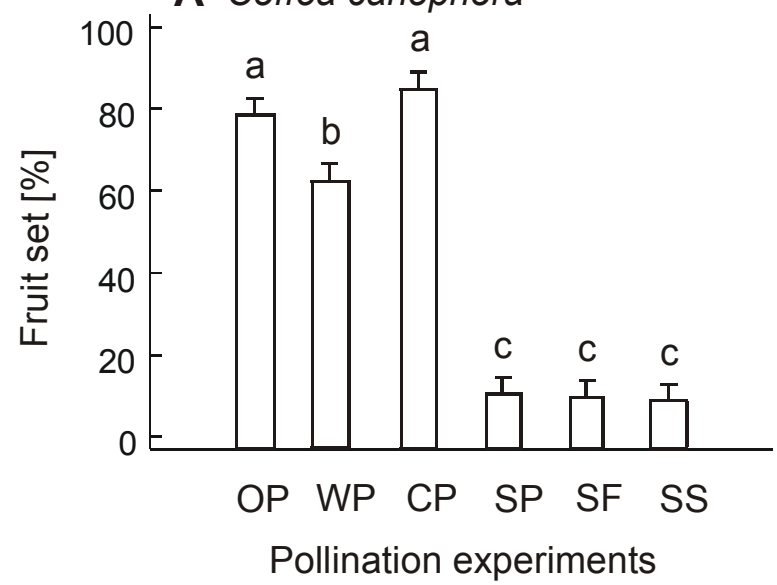

Fig. 1A: Fruit set of C. canephora after different pollination treatments. Mean fruit set of $C$. canephora: $d f=359, F=205.06, p<0.001, n=$ 360 branches in 15 sites (means $+1 \mathrm{SE}$ ).
B Coffea arabica

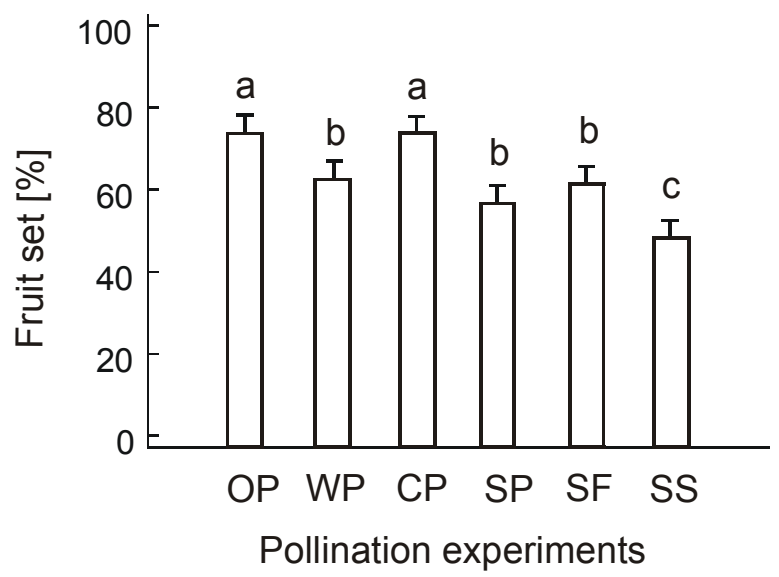

Fig. 1B: Fruit set of $C$. arabica after different pollination treatments. Mean fruit set of $C$. arabica: $d f=575, F=18.39 p<0.001, n=576$ branches in 24 sites (means $+1 \mathrm{SE}$ ).

-> Different letters show significant differences between experiments. OP, open pollination (insects and wind); WP, wind pollination; CP, cross pollination (between plant); SP, self pollination (within-plant); SF, self pollination (within-flower); SS, spontaneous selfing (Control).

\section{Flower visitation}

We found 33 species and 2269 individuals of bees visiting C. canephora flowers within 1125 min observation time (96.8\% species saturation according to the ACE method; Colwell, 1997) and 29 species and 2038 individuals of flower-visiting bees in C. arabica within the $1800 \mathrm{~min}$ observation time (96.4\% species saturation) (Table 1). Flowers of $C$. canephora were visited by significantly higher numbers of bee species than those of $C$. arabica in the 15 coffee fields where both species could be observed $(t=-3.202, p=0.006, n=15)$, and the number of bee individuals was also significantly higher in $C$. canephora $(t=-3.418, p=0.004, n=15)$. Total bee communities visiting the two coffee species differed by four additional solitary bee species observed at $C$. canephora, but not at $C$. arabica [Amegilla sp., Chalicodoma (Callomegachile) incisum, and two unidentified Halictidae], even though we sampled bees on C. arabica in nine additional fields. All other bee species were found on both coffee species. The same social bee species were found at C. canephora and C. arabica (Table 1). We found 231 more bee individuals in C. canephora, although we sampled in only 15 coffee fields, in comparison to the 24 coffee fields sampled for C. arabica (Table 1). 
Table 1: Flower-visiting bee species of Coffea canephora and C. arabica. Values are numbers of individuals seen within the observation time (1125 min for C. canephora, $1800 \mathrm{~min}$ for C. arabica).

\begin{tabular}{|c|c|c|}
\hline Flower-visiting bees & $\begin{array}{c}\text { No. C. canephora } \\
\text { individuals }\end{array}$ & $\begin{array}{c}\text { No. C. arabica } \\
\text { individuals }\end{array}$ \\
\hline \multicolumn{3}{|l|}{ Social bees } \\
\hline Apis cerana & 156 & 269 \\
\hline Apis dorsata binghami & 271 & 229 \\
\hline Apis nigrocinta & 404 & 343 \\
\hline Trigona (Heterotrigona) sp. 1 & 83 & 19 \\
\hline Trigona (Heterotrigona) sp. 2 & 198 & 154 \\
\hline Trigona (Lepidotrigona) terminata & 224 & 106 \\
\hline Trigona ssp. & 27 & 23 \\
\hline Total & 1363 & 1143 \\
\hline \multicolumn{3}{|l|}{ Solitary bees } \\
\hline Amegilla sp. aff. samarensis & 17 & 20 \\
\hline Amegilla sp. zonata-group & 15 & - \\
\hline Amegilla whiteheadi & 47 & 37 \\
\hline Chalicodoma (Callomegachile) terminale & 8 & 5 \\
\hline Chalicodoma (Callomegachile) incisum & 10 & - \\
\hline Chalicodoma (Eumegachinana) tub. tuberculatum & 35 & 28 \\
\hline Ceratina (Ceratinidia) rugifrons & 20 & 26 \\
\hline Coelioxys smithii & 13 & 5 \\
\hline Creightonella frontalis atrata & 115 & 101 \\
\hline Halictidae 9 & 51 & - \\
\hline Halictidae 18 & 7 & - \\
\hline Halictidae 21 & 38 & 72 \\
\hline Halictidae 22 & 61 & 74 \\
\hline Heriades sp. 1 & 161 & 113 \\
\hline Heriades sp. 2 & 50 & 47 \\
\hline Lipotriches sp. & 13 & 67 \\
\hline Megachile sp. aff. bakeri & 18 & 17 \\
\hline Nomia (Thoraconomia) thoracica & 56 & 105 \\
\hline Paracella sp. 1 & 27 & 21 \\
\hline Paracella sp. 2 & 35 & 10 \\
\hline Patellapis (Pachyhalictus) sp. & 3 & 15 \\
\hline Thyreus nitidus quartinae & 9 & 10 \\
\hline Torridapis ducalis & 17 & 24 \\
\hline Xylocopa (Koptortosoma) aestuans & 22 & 33 \\
\hline Xylocopa (Zonohirsuta) dejeanii & 45 & 53 \\
\hline Xylocopa (Koptortosoma) smithii & 13 & 12 \\
\hline Total & 906 & 895 \\
\hline
\end{tabular}

\section{Discussion}

The main finding of our study is that both coffee species profit from cross-pollination by bees. Using an experimental approach on a large spatial scale we could quantify the relative contribution of bees and wind as pollen vectors as well as differences between self- and crosspollinated plants. Fruit set of $C$. canephora was significantly more improved by cross pollination than fruit set of $C$. arabica, which showed a high degree of self-compatibility. The 
fruit set of C. canephora and C. arabica, following cross pollination by hand and by open pollination (insect and wind pollination), was significantly higher than fruit set of wind or manually self-pollinated flowers.

C. canephora is generally assumed to be a self-sterile wind-pollinated plant (Free 1993), although indirect evidence of enhanced fruit set due to insect pollination exists (Le Pelley, 1973, Crane \& Walker 1983). A related study of Willmer and Stone (1989) confirms the selfsterility of C. canephora but found a much lower importance of wind pollination. A possible reason could be the different weather conditions. In our study period the weather was unusually dry during the flowering time, which should enhance possible wind pollination.

Although C. arabica is reported as a self-fertile species (Free 1993), an increase of fruit set through cross pollination took place. The fact that some flowers produced fruits even in the absence of any external pollen vector (the control treatment) indicates that $C$. arabica may be amphicarpic, i.e. that some flowers need cross pollination, whereas others develop fruits even after spontaneous self pollination (see Roubik 1995; Raw \& Free 1977). Several authors have shown that cross pollination on $C$. arabica increases the amount of fruit set, and also the differences between cross pollination and spontaneous selfing differed in these studies: Taschdjian (1932) found a 54\% higher fruit set in cross-pollinated C. arabica, Krug and Costa (1947) 10\%, Carvalho and Krug (1949) 4\%, and Reddy et al. (1988) a 17\% higher fruit set compared to spontaneously self-pollinated flowers, so cross pollination appears to be generally important in C. arabica. However, these results are only based on hand-pollination experiments with bagged flowers or caged coffee plants and are not related to the effect of naturally occurring pollinator communities. In two studies, caged coffee shrubs with honey bees had a $52 \%$ higher fruit set than the control without caged honey bees (Nogueira-Neto et al. 1959; Raw \& Free 1977), and open- pollinated shrubs can lead to even higher fruit set (Raw \& Free, 1977). The importance of the naturally occurring bee community for pollination of $C$. arabica has been shown in a recent study by Roubik (2002) in Panama, but it has not been shown before (Nogueira-Neto et al. 1959; Roubik 2002).

We found a high diversity of flower-visiting bee species, with 33 species in $C$. canephora and 29 species in C. arabica. In Jamaica Raw and Free (1977) observed only four bee species visiting the flowers of $C$. arabica. In a recent study by Roubik (in press) in Panama, 22 flower-visiting bee species were observed on C. arabica. For C. canephora four bee genera, Apis, Trigona, Creightonella and Amegilla, are described as frequent flower visitors in Papua New Guinea (Willmer \& Stone 1989). We also found these four genera, but also several other genera in Indonesia. Species richness and abundance of flower-visiting bees 
were higher in C. canephora than in C. arabica, which may be explained by differences in the floral biology. Both species have flowers with a strong smell, but in C. canephora, the flowers are much bigger and coffee shrubs produce more flowers. The high diversity of flower-visiting bees on coffee in our study compared to other studies may be explained by the absence of introduced honey bees, which are the dominant flower visitors on coffee in most other tropical regions (Roubik 2002).

In general, self-sterile species benefit much more from cross pollination, especially by pollinating animals, than self-fertile species (Burd 1994; Larson et al. 2000). However, our results show that even fruit set of a self-fertile crop species can be improved by cross pollination. When we consider the potential increase of coffee harvest by improved management of pollinators, we have to take into account that optimal pollination of all flowers of a shrub may result in nutrient limitation within one year or in the following year (Zimmerman \& Pyke 1988; Campbell \& Halama 1993). Cross-pollinated flowers per branch may receive more than their share of the plant's resources, giving a higher fruit set per flower than could be achieved if all the flowers per plant had been manually cross-pollinated. Second, fruit set in one pollination episode, or even in one year may be higher or lower than in further years (Zimmerman \& Pyke 1988). To show the full lifetime reproductive success of a specific plant, pollination experiments would have to be done with a whole plant over several pollination episodes, but this is rarely possible. Additionally, the high fruit set of open-pollinated flowers in our study suggests that at least within-year resource redistribution to the hand-pollinated branches did not play a significant role.

The self-sterility of $C$. canephora could be a result of genetically induced self-incompatibility, prezygotic self-incompatibility or of inbreeding depression after self-pollination. Genetical self-incompatibility seems unlikely, because this would lead to even lower fruit set upon selfing (generally to $<5 \%$, G. Ostermeijer, personal communication 2002, Institute for Biodiversity and Ecosystem Dynamics, University of Amsterdam), and would also give a lower fruit set after cross pollination because of incompatibility of some donors. Therefore prezygotic self-incompatibility or strong inbreeding depression appears to be more likely.

In conclusion, the results indicate that both coffee species, although they differ in pollination biology, significantly profit from pollination through natural pollinators. This is of economic importance, and coffee farmers should therefore consider enhancement of bee populations as part of their coffee field management. This could be done by a reduced use of pesticides, by providing nesting sites for solitary bees, and by improving pollen and nectar availability for bees. Nesting sites could be improved by establishing earth banks for ground-nesting bees 
(Willmer \& Stone 1989), and by preserving old shadow trees for bees using wood as nesting sites. Also trap-nests of reed internodes can provide nesting sites for several solitary bees (Tscharntke et al. 1998; Klein et al. 2002a). Raw and Free (1977) suggested that coffee farmers should keep honeybee colonies in their fields during the flowering period to obtain greater yields. Other studies indicate that solitary bees are the more effective pollinators (Willmer \& Stone 1989; Klein et al. 2002a). If solitary bees are the better pollinators, the introduction of honeybees should be carefully taken into consideration, because the introduction of social bees, at least of non-native honey bees, should lead to a decline of solitary bees. We suggest the improvement of coffee fields be achieved with more nesting sites for solitary bees, more open ground for ground-nesting bees, and old or dead trees for bees using those as nesting sites.

Acknowledgment The authors thank Dr. Donald B. Baker of the Oxford University Museum of Natural History for the identification of solitary bees; Prof. David Roubik, Dr. Judith Slaa, Dr. Gerard Oostermeijer, Prof. Sarah A. Corbet, and Prof. Nick Waser for helpful comments on the manuscript, Prof. Dr. Gerhard Gerold and Dr. Veronika Fuest (Göttingen), Dr. Damayanti Buchori and Dr. Diah Ratnadewi (Bogor), and Dr. Elim Somba and Dr. Silvia Werner (Palu) of the German-Indonesian Research Project STORMA (Stability of Tropical Rainforest Margins) for support and help, Eichel Tamalagi for field assistance, the family Kabih for accommodation; the Indonesian smallholders in the Napu valley for their permission to do experiments in their fields and for helpful information, and the Deutsche Akademische Austauschdienst and the Deutsche Forschungsgemeinschaft for financial support. 


\title{
3 FRUIT SET OF HIGHLAND COFFEE INCREASES WITH THE DIVERSITY OF POLLINATING BEES
}

\begin{abstract}
The worldwide decline of pollinators may negatively affect fruit set of wild and cultivated plants. Here we show that fruit set of the self-fertilising highland coffee (Coffea arabica) is highly variable and related to bee pollination. In a comparison of 24 agroforestry systems in Indonesia, fruit set of coffee could be predicted by the number of flower-visiting bee species and ranged from about 60\% (3 species) to 90\% (20 species). Diversity, not abundance, explained variation in fruit set, so the collective role of a species rich bee community was important for pollination success. Additional experiments showed that single flower visits of the rare solitary species led to higher fruit set than the abundant social species. Pollinator diversity was affected by two habitat parameters indicating guild-specific nesting requirements: Diversity of social bees decreased with increasing forest distance, whereas diversity of solitary bees increased with increasing light intensity of the agroforestry systems. These results give empirical evidence for a positive relationship between ecosystem functions such as pollination and biodiversity. Conservation of rainforest adjacent to adequately managed agroforestry systems could improve the yields of farmers.
\end{abstract}

Keywords: agroforestry systems, Coffea arabica, conservation, diversity-function relationship, landscape context, pollinator limitation

\section{Introduction}

Almost all flowering plant species of tropical rainforests are pollinated by animals (Bawa 1990) and one third of the human diet in tropical countries is derived from insect-pollinated plants (Crane \& Walker 1983), so the worldwide decline of pollinators has potential consequences for the stability of crop yields (Allen-Wardell et al. 1998; Kevan \& Philipps 2001). The highland coffee (Coffea arabica L.) is one of the major tropical cash crops and has been considered to be a self-fertilising plant (Rehm \& Espig 1991; Free 1993). It has only recently been shown that fruit set of the highland coffee increases with cross pollination by bees (Klein et al. in press a; Roubik 2002a). Pollinator limitation has usually been related to the visitation rate or abundance of pollinators (Kunin 1993; Larson et al. 1999; Steffan- 
Dewenter \& Tscharntke 1999; Cunningham 2000; Herrera 2000; Parker \& Haubensack 2002; Roubik 2002a), and only a recent study of Kremen et al. (2003) shows that bee diversity is essential for sustaining pollination services.

Fragmentation and destruction of natural or semi-natural habitats may result in the loss of bee diversity and a disruption of plant-pollinator interactions (Rathcke \& Jules 1993; Renner 1998; Cane 2001; Steffan-Dewenter et al. 2002), but experimental evidence is still extremely rare (Steffan-Dewenter \& Tscharntke 1999; Cunningham 2000; Cane 2001; Steffan-Dewenter et al. 2002). The quality of the landscape matrix, with respect to the distance of crops from natural forest or other source habitats, may be important for many species (Perfecto \& Vandermeer 2002). Fragmentation of tropical forest and the change to a mosaic of natural forest and agroforestry is known to greatly affect pollinator communities (Aizen \& Feinsinger 1994). Coffee is traditionally grown under a canopy of shade trees. These traditional coffee agroforestry systems have relatively high biodiversity compared to unshaded monocultures (Perfecto \& Vandermeer 1996, Moguel \& Toledo 1999). One reason for the high biodiversity in shaded agroforestry systems is the structural and floristic complexity (Perfecto \& Vandermeer 1996). Intermediate degrees of shade improve the coffee yield, but more than 50\% shade causes high losses (Muschler \& Bonnemann 1997; Soto-Pinto et al. 2000). Microclimatic conditions of agroforestry systems affect the flower visitation by bees (Klein et al. 2002a), so fruit set of coffee may also suffer.

In this study we analysed the effects of bee diversity and abundance on the fruit set of the highland coffee in 24 agroforestry coffee fields, differing in shade and forest distance. We focused on the following questions:

1. Does fruit set of highland coffee depend on pollinating bees, and is bee diversity or bee abundance more important?

2. Are the social or the solitary bees the more efficient pollinators on C. arabica?

3. Do distance to the nearest forest and shading of coffee influence the diversity of flower-visiting bees and the resulting fruit set? 


\section{Materials and methods}

\section{Study area and experimental sites}

Coffee pollination was studied from November 2000 to March 2001 and from July 2001 to October 2001 at the margin of the Lore-Lindu National Park, Central Sulawesi (Indonesia), $100 \mathrm{~km}$ southwest of the city of Palu, in the villages Wuasa, Watumaeta, Alitupu, and Kaduwaa. The 24 study sites, i.e. the agroforestry coffee fields, were characterised by shade level and vegetation. Light intensity per study site was measured with a luxmeter (digital light gauge with four ranges from $0-1999 \mathrm{~W} / \mathrm{m}^{2}$ ) and under standardised conditions (on the ground and on sunny days, 0900 - 1500) to calculate a mean of 20 measurements. The vegetation was mapped twice per study site, within a $25 \mathrm{~m}^{2}$ plot for herbs and within a $100 \mathrm{~m}^{2}$ plot for shrubs and trees, resulting in estimates of the number of total plant species and the percentage of vegetation cover. Percent cover of coffee plants in flower and percent cover of all non-coffee plants in flower (which were all herbs) were recorded for each site to estimate the resource availability for flower-visiting bees. Distance to the nearest forest showed a range from inside the forest margin to a distance of $1,415 \mathrm{~m}$, measured with GPS (Global Positioning System 12 from Garmin International, Olathe, Kansas, USA).

\section{Flower-visiting bees and fruit set}

Flower-visiting bees on C. arabica were observed from 28 December 2000 to 9 January 2001. The flowers generally open just before dawn and last two days, but mostly, depending on the weather conditions, a coffee flower is attractive for flower-visiting bees for only one day. At each study site we observed flower visitors for 25 minutes on each of three different days. Every day we observed another full-blooming coffee plant than the day before with about 100 flowers on sunny days between 0900 and 1400. All flower visitors were counted within the altogether 75 minutes. After each 25-minute observation interval, bees were caught for 5 minutes by sweep netting for further species identification. Social bees were identified with the help of a collection from Gard Otis, University of Guelph, Canada. Solitary bees were identified by Donald B. Baker, Oxford University Museum of Natural History, UK.

For each of the three treatments, open pollination, cross pollination by hand, and selfpollination by hand, we selected four coffee shrubs per study site $(4 * 3$ branches in each of the 24 sites resulting in altogether 288 branches). Bags of very fine nylon mesh gauze $(10 \mu \mathrm{m})$ were used for the hand- and self-pollination experiments to exclude wind pollination and were fixed on the coffee branches one to six days before flowering, following Willmer and Stone (1989). Sticky glue was put on the branch beneath the bagged flowers to exclude ants. Pollen was transferred to stigmas with a brush on the first day of flower opening. The numbers of 
flowers on the observed bagged and open branches were tagged and counted. Hand pollination and open pollination experiments were conducted in the same week as flowervisitors were counted. Five weeks after the end of the major flowering period, bags were removed and numbers of green ovules were counted on tagged hand- and open-pollinated branches.

At the beginning of June 2001, ten coffee plants at one coffee site (unshaded polyculture) were selected to experimentally test the pollen transfer efficiency of different bee species. Twenty branches with dense and mature buds were bagged on each of the ten plants four days before flowering, using fine nylon mesh-gauze $(10 \mu \mathrm{m})$. When the flowers started to open, the bags were removed (one by one), so the bees could visit the still virginal flowers. Immediately after one bee had visited a single flower, this flower was marked with a speciesspecific colour and the branch was bagged again. After five weeks, we removed the bags from the fruiting branches and counted the numbers of green ovules on marked flowers only. Normally two ovules develop into a coffee fruit. Sometimes only one of the two ovules in a coffee flower develops into a fruit, a condition known as 'pea berry' (Raw \& Free 1977). We found only $0.92 \%$ of such 'pea berries' in 12,000 coffee fruits. Therefore we neglected possible differences between 'pea berries' and complete fruits in our study. Terminal flowers may have smaller fruits and a lower probability of fruit set than basal flowers (Corbet 1999), but in our experiments we only observed terminal flowers, so these possible differences did not affect our results.

\section{Statistics}

Statistical analyses were performed using the software 'Statgraphics plus for Windows 3.0' (Manugistics 1997). All data were tested for normality and transformed if necessary. The independent variables blossom cover of coffee and blossom cover of herbs were always $\log _{10}$ transformed and the independent variable forest distance was always square root transformed (Sokal \& Rohlf 1995). After transformation to normality we tested on correlations between the five independent habitat factors. Stepwise multiple linear regression analyses with backward selection examined which independent habitat factors were most important for the dependent variables number of all bee species and individuals and separately for social and solitary bee species, individuals and fruit set. The best-fitted habitat factor was shown in a simple linear regression model with the dependent variable. We used t-test to compare the means of fruit set between social and solitary bees. To analyse the effect of bee diversity on the spatial variability of fruit set, we calculated the coefficient of variation $(\mathrm{CV})$ of fruit set 
resulting from open pollination for three bushes per study site. We estimated the total species richness of flower-visiting bees per site with 100 randomisations in five-minute intervals with the estimator ACE (Abundance-based Coverage Estimator of species richness) with the programme Estimate S, Version 5 (Colwell 1997). The proportion of sampled and estimated species richness was calculated for each study site and the mean value for all sites are shown. Arithmetic means \pm standard errors are given.

\section{Results}

The number of flower-visiting bee species in the 24 agroforestry systems was closely related to fruit set and explained $45 \%$ of the variance (Fig. 1A), whereas the number of bee individuals was not related to fruit set (Fig. 1B). The number of bee species and the number of bee individuals were positively correlated $\left(F=8.98, r^{2}=0.289, n=24, p=0.007\right)$. Fruit set was correlated with both, the number of social bee species $\left(F=12.33, r^{2}=0.359, n=24, p=\right.$ $0.002)$, and the number of solitary bee species $\left(F=8.91, r^{2}=0.288, n=24, p=0.007\right)$. This pattern of pollinator limitation was further tested with manual cross pollination of flowers. In this case, fruit set was not correlated with the number of bee species (Fig. 1C), so the highly significant correlation between bee diversity and fruit set was not confounded by factors such as nutrient limitation or plant growth. Additionally, we calculated the difference between fruit set values after open pollination minus fruit set after experimental cross pollination. This difference increased with increasing bee diversity $\left(F=5.60, r^{2}=0.203, n=24, p=0.027\right)$, thereby giving direct evidence for pollination limitation. The coefficient of variance $(\mathrm{CV})$ of fruit set for open-pollinated flowers was negatively correlated to bee diversity $\left(F=6.76, r^{2}=\right.$ $0.235, n=24, p=0.016$ ), indicating that high bee diversity reduced the spatial variability of fruit set. 

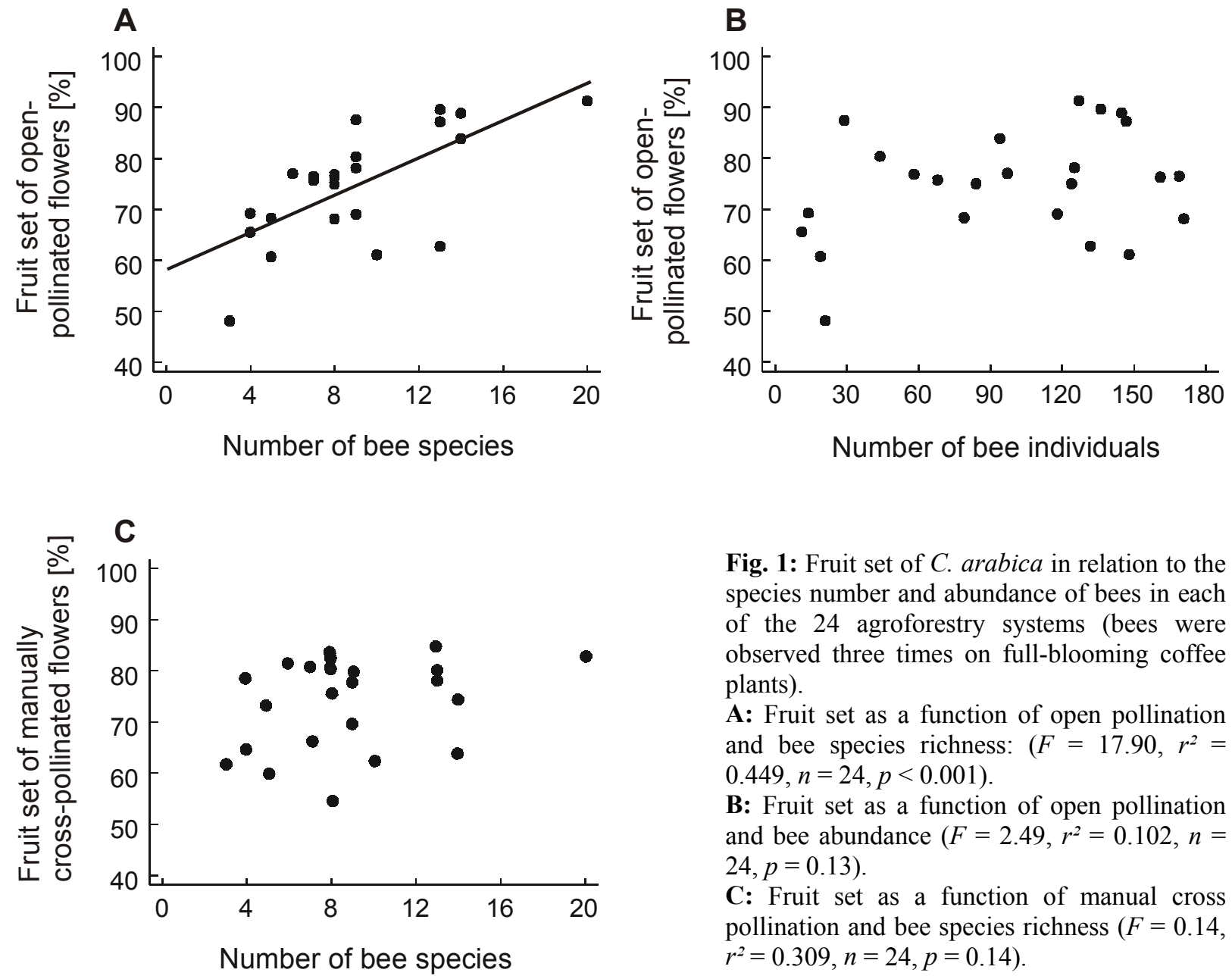

Fig. 1: Fruit set of $C$. arabica in relation to the species number and abundance of bees in each of the 24 agroforestry systems (bees were observed three times on full-blooming coffee plants).

A: Fruit set as a function of open pollination and bee species richness: $\left(F=17.90, r^{2}=\right.$ $0.449, n=24, p<0.001)$.

B: Fruit set as a function of open pollination and bee abundance $\left(F=2.49, r^{2}=0.102, n=\right.$ $24, p=0.13$ ).

C: Fruit set as a function of manual cross pollination and bee species richness $(F=0.14$, $\left.r^{2}=0.309, n=24, p=0.14\right)$.

The mechanism of this relationship between diversity and ecological function was tested using further pollination experiments. We observed 277 flower visits from 15 species on virginal (previously bagged) coffee flowers. Pollination efficiency of solitary bee species was significantly higher than of social bee species. On average, flower visitation by solitary bees resulted in $87.3 \%$ and by social bees in $74.7 \%$ fruit set $(t=-2.31, n=7$ social +8 solitary bees, $p=0.019$, see Table 1). 
Table 1: Pollination efficiency of social and solitary bees. Fruit set after a single visit of a specific bee species to a single, virginal previously bagged coffee flower was analysed. The number of single-visit experiments for each species with the proportion of flowers, which developed fruits is given. Additionally, the frequency of flower visitation within altogether $75 \mathrm{~min}$ per study site is given.

\begin{tabular}{l|cc|c} 
Bee species & $\begin{array}{c}\text { Number of } \\
\text { replicates }\end{array}$ & $\begin{array}{c}\text { Fruit set } \\
\text { \% }\end{array}$ & $\begin{array}{c}\text { Frequency of } \\
\text { flower-visitors }\end{array}$ \\
\hline (A) Social bees & 51 & & \\
Apis nigrocinta & 56 & 76.5 & 343 \\
Apis dorsata binghami & 13 & 82.1 & 229 \\
Apis cerana & 20 & 80.0 & 269 \\
Trigona (Lepidotrigona) terminata & 12 & 75.0 & 106 \\
Trigona sp. 3 & 12 & 66.7 & 23 \\
Trigona (Heterotrigona) sp.1 & 12 & 58.3 & 19 \\
Trigona (Heterotrigona) sp.2 & Sum 176 & Mean $74.7 \pm 3.51$ & Sum 1,143 \\
\hline & & & \\
(B) Solitary bees & 14 & 85.7 & 57 \\
Amegilla sp. & 5 & 60.0 & 28 \\
Chalicodoma (Callomegachile) clotho & 10 & 90.0 & 26 \\
Ceratina sp. & 20 & 90.0 & 101 \\
Creightonella frontalis & 11 & 90.9 & 146 \\
Halictidae gen. sp. & 28 & 92.9 & 113 \\
Heriades sp. & 4 & 100 & 33 \\
Xylocopa (Koptotorsoma) aestuans & 9 & 88.9 & 53 \\
Xylocopa (Zonohirsuta) dejeanii nigrocerulea & Sum 101 & Mean $87.3 \pm 4.16$ & Sum 557 \\
\hline
\end{tabular}

Table 2: Results of stepwise multiple regression analyses for the effects of light intensity, forest distance, blossom cover of coffee, blossom cover of herbs, and number of plant species on species richness and abundance of solitary and social bees and fruit set of open-pollinated, cross-pollinated, and self-pollinated coffee. Only significant relationships are shown. Cross- and self pollination, which did not show a relation with any variable is demonstrated by n.s. $=$ non significant.

\begin{tabular}{|c|c|c|c|c|}
\hline Dependent variables & $\begin{array}{l}\text { Habitat factor } \\
\text { (independent variables) }\end{array}$ & $t$ Statistic & $p$-value & $r^{2}$ \\
\hline \multirow{3}{*}{ Number of all bee species } & Light intensity $\left[\mathrm{W} / \mathrm{m}^{2}\right]$ & 5.19 & $<0.001$ & \\
\hline & Forest distance $[\mathrm{m}]$ & -4.81 & $<0.001$ & \\
\hline & Final model & & & 77.79 \\
\hline Number of all bee individuals & Light intensity $\left[\mathrm{W} / \mathrm{m}^{2}\right]$ & 4.98 & $<0.001$ & 52.98 \\
\hline \multirow[t]{3}{*}{ Number of solitary species } & Light intensity $\left[\mathrm{W} / \mathrm{m}^{2}\right]$ & 5.29 & $<0.001$ & \\
\hline & Number of plant species & 2.75 & 0.012 & \\
\hline & $\begin{array}{l}\text { Final model } \\
\text { Light intensity }\left[\mathrm{W} / \mathrm{m}^{2}\right]\end{array}$ & 383 & $<0001$ & $\begin{array}{l}74.07 \\
3996\end{array}$ \\
\hline Number of social species & Forest distance $[\mathrm{m}]$ & -8.90 & $<0.001$ & 78.26 \\
\hline Number of social individuals & Light intensity $\left[\mathrm{W} / \mathrm{m}^{2}\right]$ & -5.71 & $<0.001$ & 59.67 \\
\hline \multirow{3}{*}{ Fruit set of open pollination } & Forest distance $[\mathrm{m}]$ & -2.83 & 0.010 & \\
\hline & Light intensity $\left[\mathrm{W} / \mathrm{m}^{2}\right]$ & 2.11 & 0.047 & \\
\hline & Final model & & & 46.35 \\
\hline Fruit set of cross pollination & & & n.s. & \\
\hline Fruit set of self pollination & & & n.s. & \\
\hline
\end{tabular}


We found 1,143 individuals of seven social bee species (Hymenoptera: Apidae) and 895 individuals of 22 solitary bee species (Hymenoptera: Apidae, Megachilidae, Halictidae), which appeared to be a good estimate of bee diversity (on average $96.4 \pm 0.88 \%$ species saturation in all study sites, Colwell 1997). The diversity of flower-visiting bees was related to characteristics of the 24 agroforestry systems. The number of plant species, blossom cover of $C$. arabica, blossom cover of all plants, light intensity, and distance to the forest were not significantly correlated with each other and were used as the five predictor variables. In stepwise multiple regressions, the number of social bee species could be best explained by the distance to the forest margin (Fig. 2A), and the number of solitary bee species by light intensity and plant diversity, which explained a further $9.4 \%$ (of altogether $74 \%$ ) of the variance (Fig. 2B, Table 2). The number of all flower-visiting bee species increased with light intensity and decreased with distance to the forest margin, explaining a further $24.4 \%$ (of altogether $78 \%$ ) of the variation. Accordingly, fruit set of coffee significantly increased with light intensity and decreased with isolation distance from the forest margin, explaining a further $9.2 \%$ (of altogether $46 \%$ ) of the variation (Table 2). Fruit set of flowers, which were manually cross- or self-pollinated, was not related to forest distance or light intensity of agroforestry distance (Table 2). The mean fruit set after self-pollination by hand was $62.4 \%$ in all agroforestry systems (Klein et al. 2003).

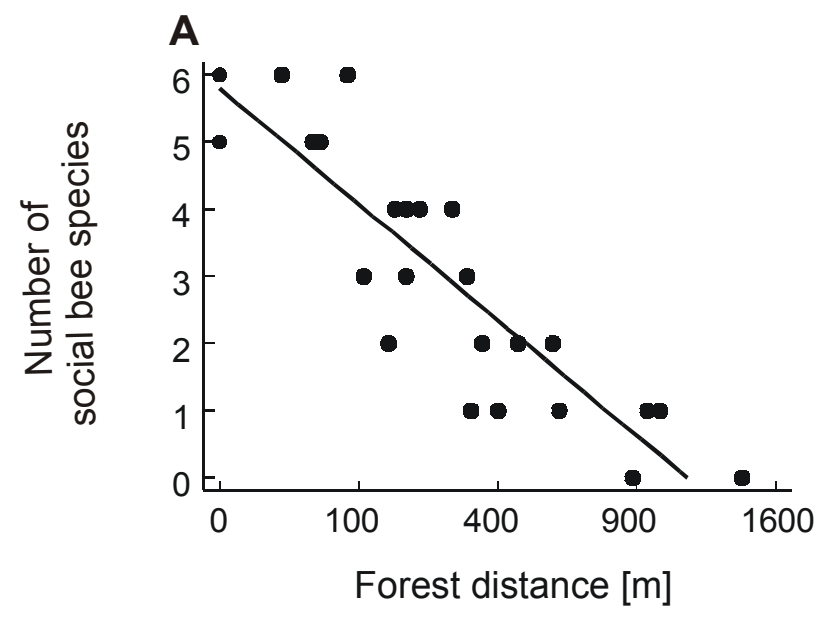

Fig. 2A: The number of social bee species in relation to forest distance: $y=5.79-0.17 \sqrt{ } x, F=$ $79.24, r^{2}=0.782, n=24, p<0.001$.

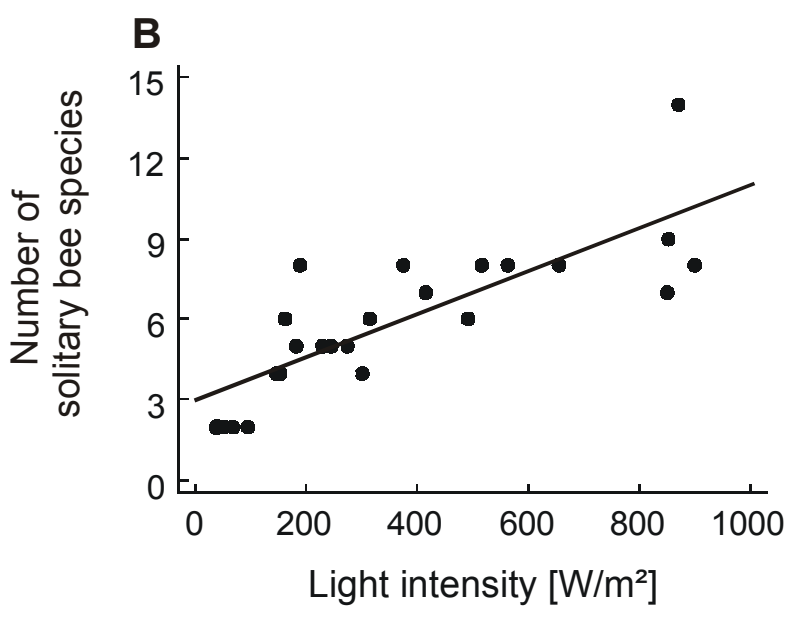

Fig. 2B: The number of solitary bee species in relation to light intensity: $y=2.97+0.01 x, F=$ $40.33, r^{2}=0.65, n=24, p<0.001$. 


\section{Discussion}

Our results show that diversity, not abundance, explained variation in fruit set, so the collective role of a species rich bee community was important for pollination success. Fruit set of open pollinated flowers ranged from $60 \%$ to $90 \%$ whereas cross-pollination by hand resulted on average in $75 \%$ fruit set and did not depend on pollinator diversity or habitat factors, indicating that pollination limitation played a major role in this system. Both, social and solitary bee species contributed to this diversity effect, but the underlying mechanism could be solved only partly in this study. In general two mechanism could be important: first complementary effects can be expected for a species-rich pollinator assemblage, thereby better covering spatial and temporal variability of flower resources as compared to one or few pollinator species. Second, a sampling effect could result in the availability of more efficient pollinator species in diverse bee communities.

Comparing abundant social and rare solitary bee species we showed that single flower visits of solitary bees resulted in fruit set with a higher probability than those of social bee species. So, the contribution of each rare bee species may have been small, but the collective role of the rare bee species turned out to be of quantitative importance. Given the same number of flower visits, the species-rich solitary bees contributed more to fruit set than the abundant social bees, partly explaining the positive relationship between fruit set and bee diversity. Multiple flower visits providing a surplus of pollen appeared to be rare, as shown by (i) the low fruit set of many sites, and (ii) the short lifespan of each flower, because a coffee flower is only attractive to bees for one day. Flower visits are extremely rare when coffee flowers on a rainy day and a second or even third visit for one flower is highly improbable. This is a common situation, because flowers start opening at the same time as the rain season starts. In our study the time we observed flower visitors was dry and sunny, so we could observe a large number of pollinating bees.

Earlier studies showed for several crops, that solitary wild bees are more efficient pollinators than the social honeybees (Corbet 1991). This could be explained by the following findings: (1) Honeybees visit more flowers per unit time than other bees, and remain longer at branches with dense flowers, thereby consecutively visiting more flowers on the same plant (Heard 1994). Thus, there is a higher probability that honeybees transfer pollen of the same plant individual. Within-plant (geitonogamous) pollination has been shown to result in lower fruit set than cross-pollination for Coffea arabica (Klein et al. 2003). (2) Honeybees are known to often collect only nectar and to contact the stigma less often (Corbet 1987). A 
pollination experiment on cashew in NE Brazil showed that a solitary bee species was more efficient in depositing pollen on stigmas than the European honeybee (Freitas \& Paxton 1998). (3) Long-tongued bees reach a hidden stigma more often than bees with a short tongue (Corbet 1996). In our study, most solitary bee species on coffee had a longer tongue than the social bees (A.M. Klein, personal observations). The corolla of coffee flowers is small and deep, so the long-tongued bees may have touched the stigma more often. (4) We observed that some social, stingless bees often bite holes at the base of the flower to reach the nectar. Stingless bees are known to damage flowers, so fruit or seed set may be negatively influenced (McDade \& Kinsman 1980; Maloof \& Inouye 2000; Irwin et al. 2001). Although, our pollination experiment showed that single visits of solitary bees resulted in a significantly higher percent fruit set, the more abundant social bee community visited about double the number of flowers, so all bee species (social bees, because of their high frequency and solitary bees, because of their high pollination efficiency) were important for coffee pollination.

Further mechanisms for this diversity-function relationship could include spatial and temporal complementarities of different bee species (Campbell \& Halama 1993). In our study the coefficient of variation of fruit set was negatively correlated with bee diversity indicating that a species-rich pollinator community reduces the spatial variability of fruit set and conserved high, constant fruit set. Other explanations seem not appropriate for our results. Species-specific preferences are known for low or high placed flowers (Hambäck 2001), but in our study only terminal flowers at a similar height were analysed. Some species prefer small, others large flower groups (Willmer \& Stone 1989), but our observations were done in a blooming period with only large flower groups. Activity patterns of bee species are also known to differ temporally, within days and between seasons (Stone et al. 1999). Variation of daily activity patterns between species may have contributed to the diversity effect whereas seasonal variation of pollinator assemblages could not play a role in our study, because we focused on one of the short flowering periods of coffee. Although coffee flowers three to four times in one year with a substantial flush of flowers, the rest of the year flowering is sparse and irregularly distributed. In such a situation the solitary bees become even more important, because the social bees are often completely absent when only few flowers are open (Willmer \& Stone 1989; Klein et al. 2002a).

Our pollination experiments were done in 24 agroforestry coffee fields, differing in shade and distance to the nearest forest, so we could also analyse the response of the two bee guilds to these two habitat factors. The diversity of social bees decreased with increasing 
forest distance, whereas the diversity of solitary bees was best explained by increasing lightintensity and increasing species numbers of plants. The forest distance is known to greatly affect social bees in the tropics, because forests offer a wealth of suitable nesting sites for the colonies of stingless bees and honey bees (Liow et al. 2001; Klein et al. 2002a). When foraging distances into the adjacent land-use systems were too long, coffee had a reduced fruit set in our study. Kremen et al. (2003) found that isolation from natural habitat affects pollination services to watermelon and this effect appeared to be more important than the local management (organic versus conventional). Only few publications show that seed set of wild plants in isolated habitats is reduced due to pollinator limitation (Steffan-Dewenter \& Tscharntke 1999; Cunningham 2000). Additionally, the quality of the agricultural matrix may affect pollinator diversity (Perfecto \& Vandermeer 2002; Steffan-Dewenter et al. 2002). Most of the solitary bees observed build nests mainly outside the dark forests and prefer less shaded and less humid agroecosystems offering open ground for the many ground-nesting species (with the exception of some leaf-cutting and carpenter bees which nest above ground) (Michener 1979; Liow et al. 2001; Klein et al. 2002a). Because diverse communities of herbaceous plants provide a diverse pollen food resource, they are generally expected to promote a diverse bee community (Siemann et al. 1999; Steffan-Dewenter \& Tscharntke 2001). This is mainly important for the solitary bees, because social bees are known to prefer mass-flowering plants (Steffan-Dewenter \& Tscharntke 2000).

In conclusion, pollination of highland coffee can no longer be considered to be an ecological service available everywhere (Allen-Wardell et al. 1998; Kevan \& Phillips 2001), but depends on a diverse bee community. The results show that the enhancement of bee diversity from three to 20 species may increase fruit set from $60 \%$ to $90 \%$. At least in our study region (Indonesia), improved land-use management should include close proximity of agroforestry systems to forests (for the enhancement of social bees) and reduced shading (for solitary bees), because of the bees' nesting requirements. Farmers should conserve bee diversity to improve their coffee production.

Acknowledgements We are grateful to D. Buchori, V. Fuest, G. Gerold, D. Ratnadewi, E. Somba, and S. Werner of the German-Indonesian Research Project STORMA (Stability of Tropical Rainforest Margins) for their great support and help. We thank D.B. Baker for the identification of solitary bees. This paper benefited from the comments of C. Kremen, T. de Jong, G. Oostermeijer, B. Schmid and several anonymous reviewers. We thank S.A. Kaisang and S.D.G. Massiri for field assistance, all Indonesian smallholders in the Napu valley for 
research permission and for helpful information, and the family Kabih for accommodation. This research was funded by the Deutsche Akademische Austauschdienst (German Academic Exchange Programme) and the Deutsche Forschungsgemeinschaft (German Science Foundation). 


\title{
4 FLOWER VISITATION AND FRUIT SET OF COFFEA CANEPHORA IN RELATION TO LOCAL AND REGIONAL AGROFORESTRY MANAGEMENT
}

\begin{abstract}
Ecological services such as pollination of crops may depend on the local agricultural management and the quality of the agricultural matrix. Fruit set of the lowland coffee (Coffea canephora), an important tropical cash crop, depends on cross-pollination by bees. The goals of this study were to analyse the distribution relation of pollinators and fruit set of coffee to the local and regional management of coffee agroforestry systems. We analysed the abundance and species richness of coffee flower-visiting bees in 15 agroforestry systems differing in forest distance, shade, blossom cover, and species richness of flowering plants in Central Sulawesi (Indonesia). The number of social bee species decreased with forest distance, whereas the number of solitary bee species increased with light intensity and increasing blossom cover of herbs and coffee. Fruit set of open pollinated flowers (in contrast to manually cross-pollinated flowers) was positively correlated with the diversity and number of flower-visiting bees. The social bees contributed more to the explanation of fruit set than the solitary bees. In agroforestry systems, a species-rich bee community with 20 species led to a higher fruit set (95\%) than a species-poor bee community (with 6 species and $70 \%$ fruit set). Pollination experiments were conducted to test the pollination efficiency of 15 flower-visiting bee species. Quantification of fruit set after single flower visits showed that the species rich but less abundant solitary bees led to higher fruit set than the abundant social bees.

Synthesis and Applications. The collective role of a species-rich and abundant bee assemblage led to high pollination success in lowland coffee. Accordingly, farmers could enhance coffee yield when they grow coffee beneath a diversity of shade tree species, but also provide sunlight (e.g. by pruning trees) to promote flowering herbs and nesting sites for solitary bees. Weed control, particularly with herbicides, should be kept to a minimum, as weeds provide a diversity of nectar and pollen resources for bees during the whole year. With respect to regional management, natural forests and forest fragments should be preserved in the vicinity of coffee agroforestry systems $(<500 \mathrm{~m})$, so that the forest-nesting social bees can bridge the distance to the coffee field.
\end{abstract}

Keywords: agroforestry systems, bees, Indonesia, isolation, lowland coffee, pollinator limitation, shade effects 


\section{Introduction}

Polycultures in a complex landscape mosaic are the typical outcome of indigenous nonindustrial agricultural management and contribute to the biodiversity of traditional agroecosystems (Altieri et al. 1987; Reichhardt et al. 1994; Toledo 1994). Increasing isolation from natural habitats affects species richness, abundance and community structure (Connor, Courtney \& Yoder 2000; Debinski \& Holt 2000), so ecological services may also suffer (Naeem et al. 1995; Tewksbury et al. 2002). Important ecological services include predation of pest insects (Moguel \& Toledo 1999; Klein et al. 2002b) and pollination of wild and cultivated plants (Rathcke \& Jules 1993; Klein et al. in press a). The fragmentation and destruction of pollinator habitats may lead to the disruption of plant-pollinator interactions (Rathcke \& Jules 1993; Renner 1998; Cane 2001; Donaldson et al. 2002; Steffan-Dewenter et al. 2002). Steffan-Dewenter \& Tscharntke (1999) found in an isolation experiment with two self-incompatible annuals that fruit set decreased with distance to the nearest natural habitat, so the quality and connectivity of the agricultural matrix, including the distance to speciesrich habitats, appears to be important for species richness and plant-animal interactions such as pollination and seed dispersal (Steffan-Dewenter et al. 2002; Perfecto \& Vandermeer 2002; Tewksbury et al. 2002). Distance to pollinator habitats may also affect plant-pollinator interactions in economically important crops (Kremen et al. 2003). In the tropics, the distance to the nearest forest is known to affect species richness of pollinators (Klein et al. 2002a; Horner-Devine et al. 2003).

Coffee is traditionally grown under a canopy of shade trees, and such agroforestry systems support relatively high biodiversity, compared with unshaded monocultures (Perfecto \& Snelling 1995; Perfecto et al. 1996; MacVean 1997; Moguel \& Toledo 1999; Conservation International 2000; Greenberg et al. 2000; Rappole et al. 2003). Therefore, coffee producers have been encouraged to maintain a dense and high diversity of shade trees in their agroforestry systems (Soto-Pinto et al. 2000). To the best of our knowledge there is no study that has analysed the effects of shade on pollinator communities and the resulting fruit set of lowland coffee.

The lowland coffee (Coffea canephora Pierre ex Froehner, syn. Coffea robusta) is an important cash crop in many tropical countries (Willmer \& Stone 1989). C. canephora is reported as a self-sterile, predominantly wind-pollinated crop (Purseglove 1968; Free 1993; Crane \& Walker 1983), and insect pollination has been assumed to make only a small contribution to total pollen transfer (McDonald 1930; Purseglove 1986). However, Willmer \& Stone (1989) found 57\% higher fruit set, and Klein et al. (2003) found 16\% higher fruit set on 
coffee plants pollinated by wind and insects in contrast to coffee plants pollinated only by wind.

In this study, we analysed the effects of forest distance, shade, and resource availability (blossom cover of herbs and of coffee, number of plant species) on flower visitation and fruit set of $C$. canephora with a focus on the following questions:

1. Do the numbers of flower-visiting bee species and individuals change with distance from forest, light intensity, and resource availability?

2. Does fruit set change with number of flower-visiting bee species and individuals, and with distance from forest, light intensity or resource availability?

3. Which bee species are the most efficient pollinators of C. canephora?

\section{Material and Methods}

\section{Study region and study sites}

The study was conducted from November 2000 to March 2001 and from June 2001 to October 2001 at the margin of the Lore-Lindu National Park, Central Sulawesi (Indonesia), $100 \mathrm{~km}$ southwest of the city of Palu, in the villages Wuasa, Watumaeta, Alitupu, and Kaduwaa. We focused on 15 different agroforestry coffee fields, differing in light intensity, forest distance, and resource availability. Percentage of the light intensity in full sunlight at the same time was measured with a luxmeter (digital light-gauge with four scopes from 0$1999 \mathrm{~W} / \mathrm{m}^{2}$ ) under standardised conditions (on the ground, on sunny days, 0900-1500) to calculate a mean of 20 measurements. The vegetation was mapped twice per study system, within a $25 \mathrm{~m}^{2}$ plot for herbs and within a $100 \mathrm{~m}^{2}$ plot for shrubs and trees, resulting in estimates of the number of total plant species and the percentage of vegetation cover. Percent cover of flowering coffee plants and percent cover of all non-coffee flowering plants (all of which were herbs) were recorded for each site to estimate the resource availability for flowervisiting bees. Furthermore, the coffee fields were located at different distances from the oldgrowth rainforest (from inside the forest margin to a distance from $900 \mathrm{~m}$ to the nearest forest). We measured the distance to the forest with GPS (Global Positioning System 12 from Garmin International, Olathe, Kansas, USA).

\section{Flower-visiting bees and fruit set of $C$. canephora}

We did our observations on coffee flower-visiting bees from 26 December 2000 to 1 January 2001. Although coffee plants bloom throughout the year, most of the year the flowering is sparse and irregularly distributed. From December to January and from June to July we 
observed a substantial flush of flowers after heavy rainfalls. The flowers generally open just before dawn and last two days. During the flowering period three different full-blooming coffee plants, with around 100 to 200 flowers per plant, were each observed for 25 minutes in each site on three sunny days between 0900 - 1400. Flower visitors were counted and identified within these 75 min. After each 25 min observation period, bees were caught by sweep netting $5 \mathrm{~min}$ for further identification of the species that could not be identified during foraging. Social bees were identified with the help of a collection from Dr. Gard Otis, University of Guelph, Canada. Solitary bees were identified by Dr. Donald B. Baker, Hope Entomological Collections, Oxford University Museum of Natural History, UK.

For each of the manual cross pollination (between-plant pollination) and open pollination experiments, we selected four coffee plants per study site $(2 * 4$ branches in each of the 15 sites, resulting in altogether 120 branches). Bags of very fine nylon mesh gauze (10 $\mu \mathrm{m})$ were used for the hand pollination experiment to exclude wind- and insect pollination and were fixed on the coffee branches one to six days before flowering, following Willmer and Stone (1989). Crawling insects, especially ants, were excluded by sticky glue on the branch beneath the bagged flowers. Pollen was transferred to stigmas with a brush on the first day of flower opening. Flowers of the observed bagged and open branches were labelled and counted. Five weeks after major flowering ended, the bags were removed and total green swollen ovules were counted.

Furthermore, at the beginning of June 2001, ten coffee plants in one study site (which was located adjacent to the old-grown natural forest and slightly shaded) were selected to experimentally test pollen transfer efficiency of different bee species. Twenty branches with dense and mature buds were bagged on each of the 10 plants four days before flowering, using nylon mesh bags $(10 \mu \mathrm{m})$. At the time when the flowers started to open, we removed the bags (one by one), so the bees could visit the still virginal flowers. After one bee visited a single flower, we marked the flower with bee species-specific colours and bagged it again. Five weeks later, we removed the bags from the flowers and counted the number of green swollen ovules to measure percentage fruit set. Almost always two ovules develop into a fruit, so fruit and seed set give almost identical results.

\section{Statistics}

Statistical analyses were performed using Statgraphics plus for Windows 3.0 (Manugistics 1997). All data were tested for normality and transformed if necessary. The independent variable, blossom cover of herbs, was always $\log _{10}$ transformed and the independent variable, 
forest distance, was always square root transformed (Sokal \& Rohlf 1995). After transformation to normality we tested correlations between the five independent habitat factors. Stepwise multiple linear regression analyses with backward selection examined which independent habitat factors were most important for the dependent variables, social and solitary bee species, bee individuals and fruit set. The best-fitted habitat factor was shown in a simple linear regression model with the dependent variable. We used t-tests to compare the means of fruit set caused by social and solitary bees. To estimate the species saturation in relation to sample size, we calculated the ratio of sampled to expected species richness for flower-visiting bees for each study site using 100 randomisations of five-minute samples with the estimator ACE (Abundance-based Coverage Estimator of species richness), within the EstimateS program, Version 5 (Colwell 1997). Arithmetic means \pm standard errors are given.

\section{Results}

\section{Flower visitation}

We found altogether 1,363 social bee individuals of seven species (Hymenoptera: Apidae) and 906 solitary bee individuals of 26 species (Hymenoptera: Apidae, Megachilidae, Halictidae). The average species saturation per study site was $96.8 \% \pm 1.46 \%, \mathrm{n}=15$, according to the ACE method (Colwell 1997). We used five independent variables to explain the distribution of the flower-visiting bees and the fruit set of coffee. Effects of local management were characterised by light intensity, blossom cover of coffee, blossom cover of herbs, and number of plant species and regional effects by the distance to the nearest forest. All these five variables were not significantly correlated with each other. In stepwise multiple regressions, we tested which of the five variables were most important for flower-visiting bees. Table 1 shows that the number of all bee species was significantly correlated with light intensity, blossom cover of herbs, blossom cover of coffee, and marginally significantly with distance from the nearest forest. The number of all bee individuals significantly correlated with light intensity and blossom cover of coffee. We separately analysed the social and solitary bees and found that the number of social bee species decreased significantly with increasing distance from the nearest forest (Fig. 1A). The number of social bee individuals decreased with forest distance and increased with blossom cover of coffee (Table 1). The number of solitary bee species was correlated with the light intensity (Fig. 1B), and the blossom cover of herbs and coffee. The number of solitary bee individuals was correlated with the number of plant species and the blossom cover of herbs (Table 1). 
A

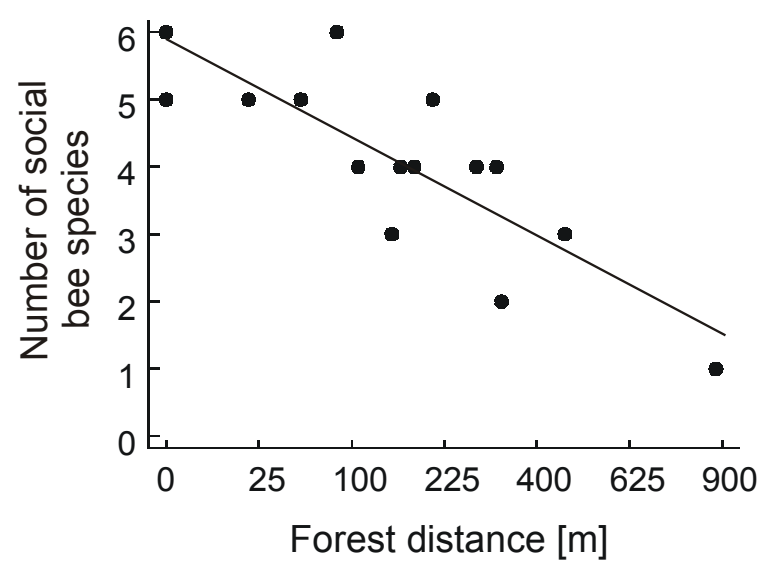

Fig. 1A: Relationship between the number of social bee species and the forest distance: $y=5.87$ $-0.14 x^{2}, F=27.63, r^{2}=0.68, n=15, p<0.001$.

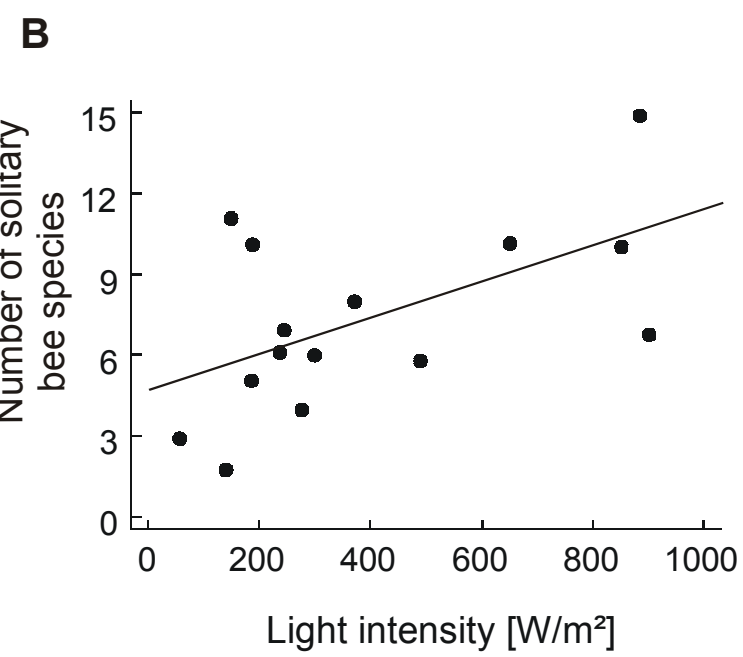

Fig. 1B: Relationship between the number of solitary bee species and light intensity: $y=4.65+$ $0.01 x, F=6.26, r^{2}=0.52, n=15, p=0.012$.

Table 1: Results of stepwise multiple regression analyses for the dependent variables number of bee species, number of individuals, and fruit set of open pollinated coffee and the independent variables light intensity, forest distance, blossom cover of coffee, blossom cover of herbs, and number of plant species. Only significant relationships are shown.

\begin{tabular}{|c|c|c|c|c|}
\hline Dependent variables & $\begin{array}{l}\text { Habitat factor } \\
\text { (independent variables) }\end{array}$ & t Statistic & p-value & $\mathbf{r}^{2}$ \\
\hline \multirow[t]{5}{*}{ Number of all bee species } & Light intensity $\left[\mathrm{W} / \mathrm{m}^{2}\right]$ & 3.23 & 0.001 & \\
\hline & Blossom cover of herbs [\%] & 3.67 & 0.004 & \\
\hline & Blossom cover of coffee [\%] & -2.49 & 0.032 & \\
\hline & Forest distance $[\mathrm{m}]$ & -2.19 & 0.054 & \\
\hline & Final model & & & 0.767 \\
\hline \multirow[t]{3}{*}{ Number of all bee individuals } & Light intensity $\left[\mathrm{W} / \mathrm{m}^{2}\right]$ & 3.58 & 0.004 & \\
\hline & Blossom cover of coffee [\%] & 3.05 & 0.010 & \\
\hline & Final model & & & 0.595 \\
\hline Number of social species & Forest distance $[\mathrm{m}]$ & -5.26 & $<0.001$ & 0.860 \\
\hline \multirow[t]{3}{*}{ Number of social individuals } & Forest distance $[\mathrm{m}]$ & -2.95 & 0.012 & \\
\hline & Blossom cover of coffee [\%] & 2.30 & 0.031 & \\
\hline & Final model & & & 0.524 \\
\hline \multirow[t]{4}{*}{ Number of solitary species } & Light intensity $\left[\mathrm{W} / \mathrm{m}^{2}\right]$ & 4.44 & 0.001 & \\
\hline & Blossom cover of herbs [\%] & 3.86 & 0.003 & \\
\hline & Blossom cover of coffee [\%] & -2.92 & 0.014 & \\
\hline & Final model & & & 0.727 \\
\hline \multirow[t]{3}{*}{ Number of solitary individuals } & Number of plant species & -2.18 & 0.050 & \\
\hline & Blossom cover of herbs [\%] & 2.01 & 0.067 & \\
\hline & Final model & & & 0.340 \\
\hline \multirow[t]{3}{*}{ Fruit set of open pollination } & Light intensity $\left[\mathrm{W} / \mathrm{m}^{2}\right]$ & 3.11 & 0.009 & \\
\hline & Forest distance $[\mathrm{m}]$ & -2.78 & 0.017 & \\
\hline & Final model & & & 0.722 \\
\hline
\end{tabular}

\section{Fruit set}

In stepwise multiple linear regression analysis, fruit set after open pollination was correlated with light intensity (Fig. 2A) and with forest distance (Fig. 2B, Table 1). The difference between fruit set after open pollination and manual cross pollination was, with marginal significance, positively correlated with the number of bee species $\left(F=4.29, r^{2}=0.49, n=15\right.$, 
$p=0.058)$, and significantly positively correlated with the number of bee individuals $(F=$ 9.06, $\left.r^{2}=0.41, n=15, p=0.010\right)$. Fruit set after open pollination was positively correlated with the number of flower-visiting bee species (Fig. 3A), and with the number of flowervisiting bee individuals (Fig. 3B). Testing social and solitary bees separately, fruit set was positively correlated with the number of flower-visiting social bee species $\left(F=15.30, r^{2}=\right.$ $0.54, n=15, p=0.002)$, and also with the number of flower-visiting social bee individuals ( $F$ $\left.=7.79, r^{2}=0.37, n=15, p=0.015\right)$. In contrast, fruit set was correlated neither with the number of flower-visiting solitary bee species $\left(F=2.02, r^{2}=0.13, n=15, p=0.179\right)$, nor with the number of flower-visiting solitary bee individuals $\left(F=0.09, r^{2}=0.07, n=15, p=\right.$ $0.770)$.

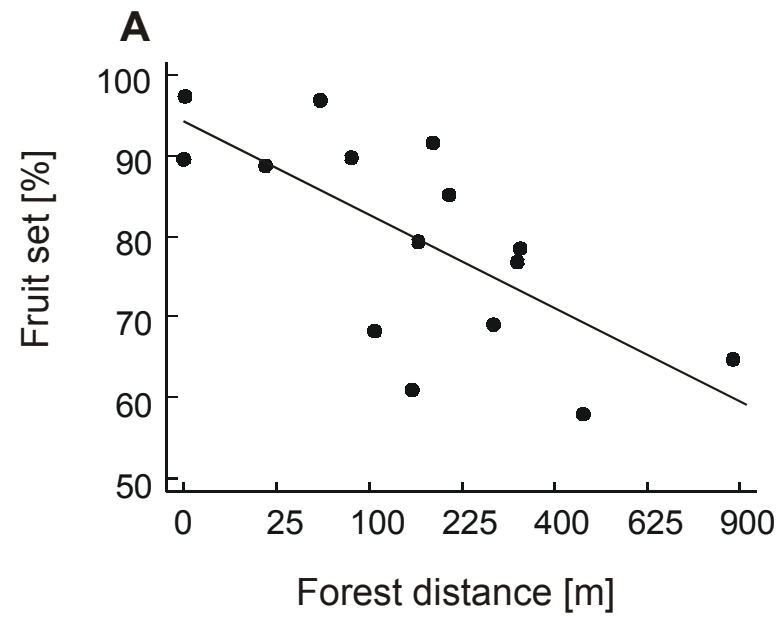

Fig. 2A: Relationship between fruit set after openpollination and forest distance: $y=94.11-1.15 x^{2}$, $F=12.92, r^{2}=0.49, n=15, p=0.003$.

\section{A}

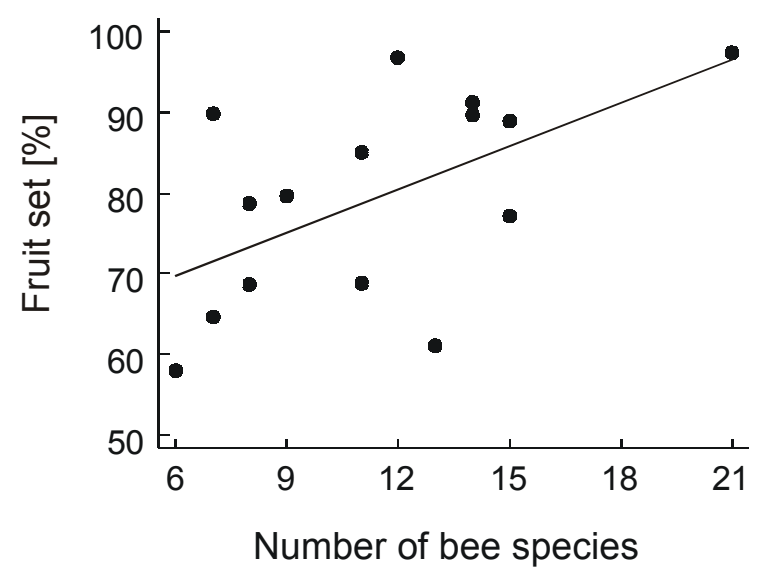

Fig. 3A: Relationship between fruit set after openpollination and the number of flower-visiting bee species: $y=59.48+1.77 x, F=5.89, r^{2}=0.31, n=$ $15, p=0.031$.

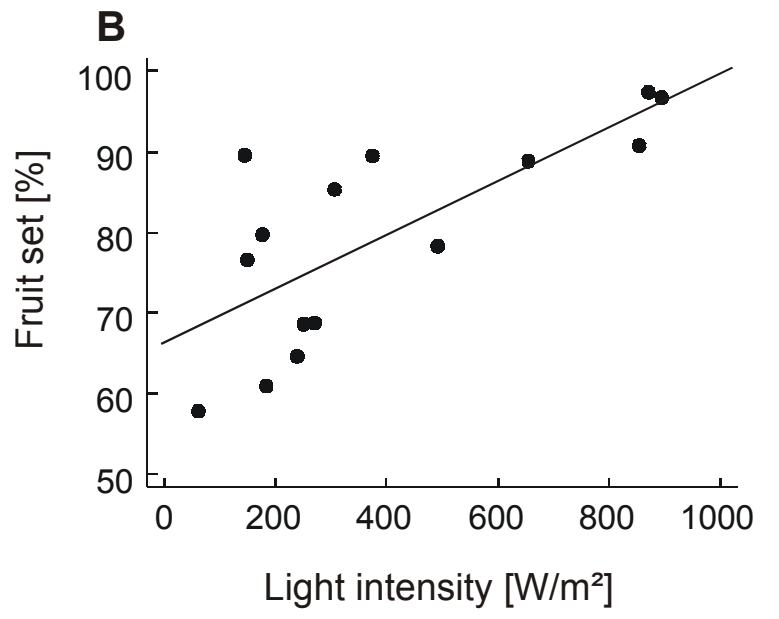

Fig. 2B: Relationship between fruit set after open-pollination and light intensity: $y=66.60+$ $0.03 x, F=15.48, r^{2}=0.74, n=15, p=0.002$.

B

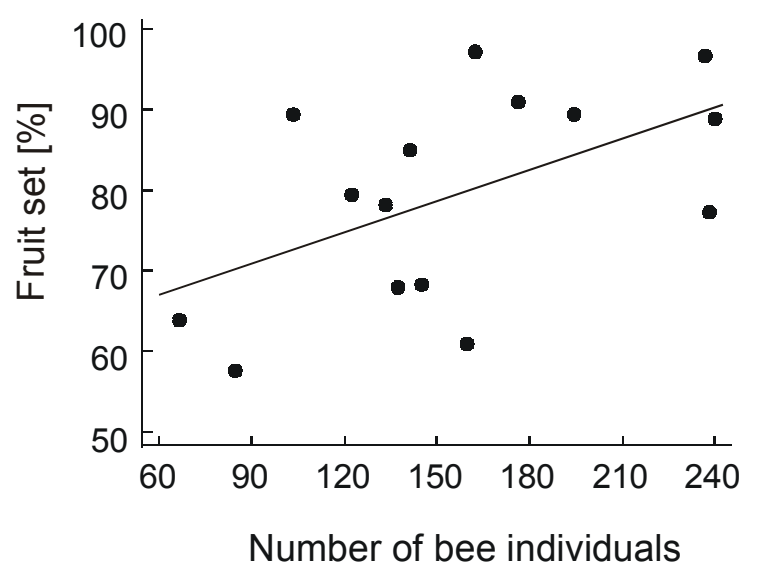

Fig. 3B: Relationship between fruit set after open-pollination and the number of flowervisiting bee individuals: $y=59.38+0.13 x, F=$ 5.40, $r^{2}=0.29, n=15, p=0.037$. 


\section{Pollination efficiency}

Species-specific pollination efficiency was experimentally tested with a number of bee species. We observed individual flower visits of 368 bees of 15 species $(7$ social and 8 solitary bees, which frequently visited coffee plants) to virginal (previously bagged) coffee flowers. The most abundant flower-visitors were three honeybee species of the genus Apis. The stingless bees of the genus Trigona were also abundant (Table 2). On average, flower visitation by solitary bees resulted in a significantly higher fruit set $(86.5 \%)$ as compared with social bees $(70.4 \%$ fruit set, $t=-3.19, n=7$ social +8 solitary bees, $p=0.007$, see Table 2$)$.

Table 2: Pollination success of single social and solitary bee visits. Results from experimentally bagged coffee flowers allowed a single visit from a single individual of a specific bee species to a single, virginal coffee flower. We show the single-visit experiments for each species with the resulting mean fruit set and the frequency of flower visitation within $75 \mathrm{~min}$.

\begin{tabular}{l|cc|c} 
Bee species & $\begin{array}{c}\text { Number of } \\
\text { replicates }\end{array}$ & $\begin{array}{c}\text { Fruit set } \\
\text { \% }\end{array}$ & $\begin{array}{c}\text { Frequency of } \\
\text { flower-visitors }\end{array}$ \\
\hline (A) Social bees & 72 & 72.22 & 404 \\
Apis nigrocinta & 60 & 71.66 & 271 \\
Apis dorsata binghami & 16 & 68.75 & 156 \\
Apis cerana & 25 & 84 & 224 \\
Trigona (Lepidotrigona) terminata & 17 & 74.71 & 27 \\
Trigona sp. & 15 & 66.66 & 83 \\
Trigona (Heterotrigona) sp. 1 & 38 & 55.26 & 198 \\
Trigona (Heterotrigona) sp. 2 & Sum 243 & Mean 70.40 & Sum 1,363 \\
\hline & & & \\
\hline B) Solitary bees & 12 & 83.33 & 89 \\
Amegilla sp. & 10 & 63.33 & 62 \\
Megachile sp. & 13 & 84.61 & 56 \\
Ceratina sp. & 28 & 89,29 & 115 \\
Creightonella frontalis & 14 & 87.57 & 161 \\
Halictidae & 34 & 94.12 & 50 \\
Heriades sp. & 4 & 100 & 22 \\
Xylocopa (Koptotorsoma) aestuans & 10 & 90 & 45 \\
Xylocopa (Zonohirsuta) dejeanii nigrocerulea & Sum 125 & Mean 86.53 & Sum 553 \\
\hline & & &
\end{tabular}

\section{Discussion}

Our study shows that both local and regional characteristics of agroforestry systems affect the species richness and abundance of flower-visiting bees and fruit set of lowland coffee, an important tropical crop. The diversity of social bees decreased with forest distance, whereas the diversity of solitary bees was best explained by increasing light intensity and increasing percentage of flowering herbs within an agroforestry system. We found higher densities of social bees within and near the forest than far from forest, presumably because forests offer a wealth of suitable nesting sites for the colonies of stingless bees and honeybees foraging into 
the adjacent land-use systems (Heard \& Exley 1994; Klein et al. 2002a). In contrast, most of the solitary bees observed built nests mainly outside the dark forests, preferring less shaded and less humid agroecosystems that offered open areas for the many ground-nesting species and herbaceous plants for pollen and nectar resources (Michener 1979; Liow et al. 2001; Klein et al. 2002a).

Local management strategies, which improve the availability of pollinating bees in coffee agroforestry systems, are still unknown in Indonesia. The most important factor for the local management of coffee is shade. This factor influences the yield of most plantation crops (Amoah et al. 1997). Shade trees influence the moisture and nutrient relations of crops and affect chemical and physical properties of the soil by deposition of litter and growth of their roots. Shade can also influence populations of insect pests, diseases, and weeds (Perfecto et al. 1996; Beer et al. 1998). Beer (1987) discusses the advantages and disadvantages of shade in coffee systems. Although shade improves growth and production of coffee, several authors argue that more than 50\% shade leads to high losses in coffee yields (Escalante 1995; Amoah et al. 1997; Muschler \& Bonnemann1997; Soto-Pinto et al. 2000). Bee community structure changes with light intensity and temperature (Klein et al. 2002a), but to our knowledge there are no publications reporting shade effects on flower-visiting bee communities on coffee and the resulting fruit set. Willmer and Stone (1989) recommended that populations of a certain solitary bee species (the ground-nesting Creightonella frontalis) should be enhanced, because this species seems to be a better pollinator than social honeybees on lowland coffee. They suggest two management strategies to improve coffee yield in Papua New Guinea. First, to create more nesting sites for ground-nesting bees, e.g. open soil on embankments, and second, to improve the availability of alternative flower resources such as weeds and hedgerow plants. In the light of our findings in Central Sulawesi, we suggest similar local management strategies. To enhance solitary bees we recommend a reduction of shade and less intensive weed control, thereby supporting a diverse herbaceous ground vegetation.

At the regional scale, species richness and abundance of social bees could be enhanced if agroforestry coffee systems were located close to natural forest. Not only the neighbourhood of natural forest favours species richness, even small, isolated forest fragments may help to retain diversity and increase the conservation value of agricultural landscapes (Horner-Devine et al. 2003). The mosaic structure of landscapes with traditionally managed agroecosystems has been shown to maintain or improve biodiversity (Altieri et al. 1987; Reichhardt et al. 1994; Toledo et al. 1994; Perfecto \& Vandermeer 2002). Habitat isolation may influence the structure of bee communities, change the foraging behaviour of 
flower-visiting bees, and reduce fruit set and gene flow of isolated plant populations (Aizen \& Feinsinger 1994; Didham et al. 1996; Steffan-Dewenter \& Tscharntke 1999; Cunningham 2000; Kremen et al. 2003). We show that the distance from agroforestry systems to natural forest affected social bees presumably, because the social bees prefer to nest in cavities of high trees (all honey bees except Apis cerana) or in cavities of dead trees lying on the ground (all stingless bees, pers. observ. A.M. Klein; Heard \& Exley 1994). In a recent study in California, habitat isolation appeared to have a greater effect on pollinating bees than local management (Kremen et al. 2003). A further factor influencing pollinators is the availability of floral resources. Social bees are known to prefer mass-flowering crops (Waddington et al. 1994). Coffee was mass-flowering during our observation period and the number of social bees showed a positive correlation with blossom cover of coffee. The solitary bees were correlated negatively with blossom cover of coffee, but positively with the blossom cover of herbs. Most solitary bees foraged on coffee, but at mass-flowering time of coffee, social bees are attracted in large numbers and solitary bees appeared to often switch to the ground vegetation (Willmer \& Stone 1989; Klein et al. 2002a). Light intensity is often correlated with the number of flowering herbs, so most solitary bees prefer open habitats (Klein et al. 2002a). Outside the mass-flowering period, we observed every month some blossoms on the coffee plants for three to seven days. At this time social bees are often absent and solitary bees are the main flower visitors (pers. observ. A.M. Klein). To enhance fruit set of single blooming flowers, populations of solitary bees should be enhanced with the suggested management strategies.

We found experimental evidence for a higher pollination efficiency of the species-rich, but less abundant solitary bee species, compared to the few, but abundant social species. Earlier studies showed that solitary wild bees are more efficient pollinators for certain crops than social bees (Corbet 1991). The difference in pollination success between these two pollinator guilds could be explained by the following findings: (1) Solitary bees switch more often between plants than social bees, and thereby provide a higher change of cross pollination (Willmer \& Stone 1989). (2) Social bees collect less pollen and more nectar than solitary bees and contact the stigma less often (Corbet 1987; Freitas \& Paxton 1998). (3) Most solitary bees have longer tongues and touch the hidden stigma more often than social bees (Corbet 1996). (4) Social, stingless bees often damage flowers, so fruit set may be reduced (Maloof \& Inouye 2000; Irwin et al. 2001). Reduced pollination is known as one major reason for low fruit set in some plant species, for example Acacia brachybotry, Centaurea scabiosa, Coffea arabica, Coffea canephora, Eremophila glabra, Lythrum salicaria (Ågren 1996; 
Ehlers 1999; Cunningham 2000; Roubik 2002, Klein et al. 2003). Both the number of species and individuals of the bee community on lowland coffee appeared to be important for overall pollination success. In contrast, fruit set of highland coffee (Coffea arabica L.) was found to be related to bee diversity, but not abundance (Klein et al. in press a). The flowers of the lowland coffee are much bigger, smell much more intensive and produce more flowers, which appeared to enhance the frequency of flower-visitors (Klein et al. 2003). Because of this higher attractiveness of $C$. canephora flowers, the abundant social bees seem to be more important in lowland coffee than in highland coffee. However, in Panama fruit set increased more than $50 \%$ by pollination of primarily non-native honeybees (Roubik 2002).

We observed the flower-visitors in one large blooming period of altogether one week. This may seem to be a short time for bee sampling, but we observed altogether a reasonable sample size of 2,269 bee individuals. Further, the main flowering periods of coffee are always extremely short. Light-intensity will not change greatly over the year, because the trees and shrubs in the agroforestry systems were all evergreen. Nevertheless, farmers should trim the trees and shrubs if the canopy will become too close over the years. The most herb species sampled are flowering all over the year, so we assume that herb species are most important to provide a continuous source of nectar and pollen for flower-visiting bees. All shade tree species sampled are flowering only at a short time in the year.

Klein et al. (2003) show in a parallel study that wind pollination leads on average to $16 \%$ lower fruit set than open pollination in C. canephora, using pollination experiments that excluded insects with coarse mesh gauze and with very fine openings to exclude wind- and insect pollination. In agroforestry systems with few pollinators (strongly shaded, plant species poor, and far from natural forest margin) fruit set of open pollination was not higher than that of wind pollination. In agroforestry systems with a species-rich bee community (medium shaded, plant species rich, located inside the margin of the natural forest) wind pollination lead to $35.5 \%$ lower fruit set than open pollination (results not shown). Overall, species-rich agroforestry systems with 20 bee species led to a higher fruit set $(95 \%)$ than that with a species-poor bee community (with 6 species and only 70\% fruit set; see Fig. 3A). Willmer and Stone (1989) found even 57\% higher fruit set on coffee plants pollinated by wind and insects in contrast to coffee plants pollinated only by wind.

In conclusion, this study provides new insights into the importance of habitat management at local and regional scales. Isolation from forests and light intensity affected the flower-visiting bee community of lowland coffee, an important cash crop in the tropics. The results indicate that a species-rich and large bee community plays a significant role for fruit 
set in this system. Coffee farmers should increase abundance and diversity of flower-visiting bees in their agroforestry systems to improve their yield. According to our results, coffee agroforestry systems should be established near the margin of natural forests or landscape management should preserve scattered forest patches, at best within a range of $500 \mathrm{~m}$ to enable social bees to bridge the distance between their main nesting habitats (forests) and the land-use system. Local management should promote a flower-rich ground layer of herbs as well as medium light intensity, to provide dry ground as nesting habitat for the species rich ground-nesting solitary bees. Further, reduced shade enhances populations of flowering herbs that offer important nectar and pollen resources for solitary bees during the whole year.

Acknowledgements We thank Dr. D. B. Baker of the Oxford University Museum of Natural History for the identification of solitary bees. We are grateful to D. Buchori, V. Fuest, G. Gerold, D. Ratnadewi, E. Somba, and S. Werner of the German-Indonesian Research Project STORMA (Stability of Tropical Rainforest Margins) for their great support and help, to E. Tamalagi, S. A. Kaisang and S. D. G. Massiri for field assistance, all Indonesian smallholders in the Napu valley for research permission and for helpful information, and the family Kabih for accommodation. We are grateful to J. Krauss and D. Veddeler for helpful comments on this manuscript. For financial support we thank the Deutsche Akademische Austauschdienst (German Academic Exchange Programme) and the Deutsche Forschungsgemeinschaft (German Science Foundation). 


\title{
5 EFFECTS OF FOREST DISTANCE ON TROPHIC INTERACTIONS AND DIVERSITY OF TRAP-NESTING BEES, WASPS, AND THEIR NATURAL ENEMIES IN TROPICAL AGROFORESTRY SYSTEMS
}

\begin{abstract}
The worldwide decline of tropical rainforests resulting from forest conversion to agroecosystems causes a mosaic landscape, dominated by simple to complex land-use systems and patchily distributed forest fragments. Agroecosystem management and landscape context can be expected to affect both species diversity and ecological functions such as trophic interactions. In Central Sulawesi (Indonesia), we studied 24 agroforestry systems, differing in the distance from the nearest natural forest $(0-1,415 \mathrm{~m})$, light intensity $(37.5$ 899.6 W/m²), and number of vascular plant species (7 - 40 species). We exposed 10 standardised trap nests for bees and wasps, made from reed and knotweed internodes in each agroforestry system. Occupied nests were collected every month, over a period totalling 15 months. A total of 13,617 brood cells were reared to produce adults of 14 trap-nesting species and 25 natural enemy species, which were almost completely parasitoids. The total number of species was negatively affected by increasing forest distance but increased with light intensity of agroforestry systems. The parasitoids in particular appeared to profit from nearby forests. Within a $500 \mathrm{~m}$ distance, the number of parasitoid species decreased from 8 to 5 , and parasitism rates fell from $12 \%$ to $4 \%$. The density of the trap-nest community varied greatly between months. Wasp, but not bee density was significantly higher in the dry season compared to the rainy season.

In conclusion, diversity as well as trophic interactions in the trap-nest community could be enhanced through (i) improved connectivity of agroforestry systems with natural forests, and (ii) local management that increases light intensity and plant species richness.
\end{abstract}

Keywords: conservation, isolation, landscape, parasitoids, phenology

\section{Introduction}

The worldwide expansion of agricultural land use results in the degradation and isolation of agroecosystems from natural habitats (Vitousek et al. 1997; Tilman et al. 2001). In tropical countries agroecosystems already dominate the landscape and natural forest is often only 
patchily distributed (Schelhas \& Greenberg 1996; Laurance \& Bierregaard 1997). As a consequence, ecosystem services provided by natural habitats may disappear. Habitat conversion and the simplification of landscape structure are the main reasons for the worldwide loss of biodiversity (Harrison \& Bruna 1999; Dale et al. 2000). Populations of species within fragmented habitats become isolated from the source populations in large natural habitats, particularly when agroforestry systems are far from the nearest natural forest. Isolation from natural habitats does not affect all species equally, and specialists of higher trophic levels, such as parasitoids, are known to be much more affected than their hosts (Tscharntke \& Kruess 1999; Davies et al. 2000). Initially, resident populations of parasitoids and predators are typically low in agroecosystems (Bosch \& Kemp 2002). Because of the poor abundance of predators and parasitoids in tropical land-use systems, pest species have an advantage in human-dominated landscapes, thereby profit from agricultural land use (Klein et al. 2002a). Agroecosystems can be expected to offer usable resources only when natural forests are nearby, because many species need different habitat types within their foraging range to fulfil their specific requirements. With respect to wild bees, many species need food resources, nest sites, and nesting material for survival, and these are often spatially separated (Westrich 1996; Steffan-Dewenter 2002). Thus, a landscape mosaic with agroecosystems in close proximity to natural habitat fragments is often important for the maintenance of biodiversity (Huston 1999; Ricketts 2001; Perfecto \& Vandermeer 2002; Steffan-Dewenter 2002; Tscharntke et al. 2002a,b). Native bee diversity may be significantly related to the proportion of natural habitat area surrounding agroecosystems (Steffan-Dewenter et al. 2002; Kremen et al. 2003).

Bees and wasps using trap nests are known to be bioindicators that are sensitive to environmental changes (Westrich 1996; Tscharntke et al. 1998). The trap-nesting community comprises different ecological groups, including (i) mutualistic species such as bees (Rathcke \& Jules 1993), (ii) species of higher trophic levels such as predatory wasps and parasitoids (Holt et al. 1999), and (iii) habitat specialists as well as generalists (Warren et al. 2001; see also Tscharntke et al. 2002b). Bees provide important ecosystem services to crops and noncrop plants (Corbet 1987; Matheson 1994), and pollination limitation has been shown to lead to significant losses in fruit set with a consequent reduction of yield (Steffan-Dewenter \& Tscharntke 1999; Richards 2001; Kremen et al. 2003; Klein et al. 2003). Wasps may control pest caterpillars (Harris 1994), but also attack beneficial predators such as spiders. In addition, the primary trap-nest inhabitants (bees and wasps) are attacked by a range of predators and 
parasitoids, and thereby may provide little known data on the strength of trophic interactions and its relation to enemy diversity (Tscharntke et al. 1998; Bosch \& Kemp 2002).

Here, trap nests were exposed over a 15 months period to analyse the community structure of bees and wasps in differently managed agroforestry systems, at different distances from the nearest natural forest.

We focused on four main questions:

1. Do the number of trap-nesting species decrease with increasing isolation from natural forest?

2. Do populations of higher trophic levels respond more sensitively to isolation from natural forest?

3. What is the relative importance of forest distance and local agroforestry characteristics such as light intensity and plant diversity?

4. How does the trap-nest community change from the dry to the rainy season?

\section{Materials and methods}

\section{Study region and agroforestry systems}

The study was carried out from December 2000 to March 2002 in the Napu valley, at the east side of the forest margin close to the Lore-Lindu National Park, in Central Sulawesi, Indonesia. This was approximately $100 \mathrm{~km}$ southeast from the city of Palu, in and around the villages of Alitupo, Kaduwaa, Watumaeta, and Wuasa. We chose 24 agroforestry systems, dominated by coffee, with different shade levels and vegetational complexity. Light-intensity was measured with a luxmeter (digital light-gauge with four scopes from 0-1999 W/m²) and under standardised conditions (on the ground, on sunny days, 0900 - 1500) to calculate the mean of 20 measurements (Table 1). The vegetation of each site was mapped twice from January to September 2001, within a $25 \mathrm{~m}^{2}$-plot for herbs, and within a $100 \mathrm{~m}^{2}$-plot for shrubs and trees, resulting in estimates of the total number of vascular plant species and the percentage of vegetation cover for each species. Percentage cover of flowering plants was recorded for each site to estimate the resource availability for the trap-nesting bee species. The agroforestry systems differed in their distance from the nearest natural forest (ranging from inside the forest margin, to a distance of $1,415 \mathrm{~m}$ from the nearest natural forest). We measured the distance to the forest with GPS (Global Positioning System from Gamin International, Olathe, Kansas, USA, Table 1). 


\section{Trap nests}

Trap-nesting bees (Apoidea) and wasps (Eumenidae, Sphecidae, Pompilidae) use holes of suitable diameter for nesting. A nest consists of one to several brood cells, and the females provide the cells with food for the larvae, bees with a nectar-pollen mixture, pompilid- and sphecid wasps with spiders, and eumenid wasps with caterpillars. Parasitoids (mostly Hymenoptera) lay their eggs in the cells and the larvae feed on their host's larvae and often also on their host's food. Predators lay their eggs in the cells and the larvae primarily feed on their host's food, so the egg of the trap-nesting species does not develop into an adult (A.M. Klein, personal observations).

Trap nests were set up in December 2000 and removed in March 2002. Ten traps were exposed in each of the 24 agroforestry systems with a solid wire in coffee or cacao shrubs, or legume shade trees such as Erythrina sp. or Gliricidia sp. at a height of $1.5 \mathrm{~m}$ to $2 \mathrm{~m}$. We put sticky glue on each wire outside the trap nests to deter ants. The standardised traps consisted of about 120 internodes of a mixture of common reed Phragmites australis (Cav.) Trin. and Japanese knotweed Reynoutria japonica Houtt, cut to a length of $20 \mathrm{~cm}$ and inserted into plastic tubes of $10.5 \mathrm{~cm}$ diameter and a length of $25 \mathrm{~cm}$. The range of internal diameters of the reed internodes varied between $2 \mathrm{~mm}$ and $20 \mathrm{~mm}$. We replaced monthly all occupied internodes with unoccupied new internodes of a similar diameter. Nests were opened in the laboratory to make a preliminary identification of species and to establish the number of brood cells per species. After the adults had emerged, species were identified and mortality due to parasitism and predation, and unknown mortality were established.

\section{Statistics}

Statistical analyses were performed using the software 'Statgraphics plus for Windows 3.0' (Manugistics 1997). All data were tested for normality and transformed if necessary to achieve normal distributed data. The independent variable forest distance was always squareroot transformed (Sokal \& Rohlf 1995). The habitat factor light intensity was highly intercorrelated with most of the vegetation parameters, so we used this parameter for multiple regression analyses as well as the number of plant species to show relations with bees, wasps, and natural enemies. The number of plant species was only slightly correlated with light intensity $\left(r^{2}=0.44, p=0.03\right)$, in contrast to the other vegetation parameters such as the percent cover of all plants $\left(r^{2}=-0.82, p<0.001\right)$, the number of herb species $\left(r^{2}=0.62, p<\right.$ 0.001 , and the percent cover of trees $\left(r^{2}=-0.96, p<0.001\right)$. The species were divided into three groups, bees, wasps, and natural enemies. In stepwise multiple linear regression 
analyses with backward selection we examined which independent habitat factor (forest distance, light intensity, number of plant species) was the best predictor for the number of all species, the number of all individuals, the number of bee species or individuals, the number of wasp species or individuals, the number of natural enemy species, and the percentage mortality due to natural enemies. For the latter two dependent variables we included also the host density in the model. Multifactor analyses of variance were used to test for group differences in the number of brood cells between months, separately for bees and wasps within the 15-month period. The differences were established using Tukey HSP intervals at the $95 \%$ confidence level, with forest distance and light intensity as covariates. We used paired t-tests to compare the mean number of brood cells between the dry and rainy season separately for bees and wasps.

\section{Results}

\section{Community structure}

Altogether, 13,617 brood cells of five bee species (Hymenoptera, Apidae), six eumenid wasp species (Hymenoptera, Eumenidae), two sphecid wasp species (Hymenoptera, Sphecidae), and one pompilid wasp species (Hymenoptera, Pompilidae) were found in 240 exposed trap nests within the 15-month. The most abundant and widespread species were the spider wasp Auplopus levicarinatus, which occupied $55.6 \%$ of all brood cells, the megachilid bee species Heriades (Michenerella) sp. aff. fulvescens with 20.2\%, and the eumenid wasp species Rhynchium haemorrhoidale umeroatrum with 17.1\%. The remaining 11 species were relatively rare and inhabited altogether only $7.1 \%$ of the brood cells (Table 1). Twenty-five species of natural enemies were found, which attacked a mean of $5.0 \%$ of all brood cells: $2.1 \%$ of bees, $9.2 \%$ of eumenid wasps, $16.9 \%$ of sphecid wasps, and $2.8 \%$ of pompilid wasps respectively. The mortality inside all brood cells for which no cause could be assigned was 14.1\% (Table 1 and Table 2).

The number of brood cells established by the bees and wasps varied greatly between months and between both years (Fig. 1A, B). The mean number of brood cells established by wasps was significantly higher in the dry season (April until September) than in the rainy season (October until March; paired t-test, $t=5.14, n=24, p<0.001$ ), but the mean number of brood cells established by bees did not differ significantly between dry and rainy seasons (paired t-test, $t=0.21, n=24, p=0.832$ ). The number of trap-nesting species was only marginally correlated with the number of natural enemy species $\left(F=3.57, r^{2}=0.14, n=24, p\right.$ 
$=0.072$ ), and the number of trap-nesting individuals was not correlated with the number of natural enemy individuals $\left(F=0.64, r^{2}=0.03, n=24, p=0.433\right)$.

Table 1: Bees (Apoidea), wasps (Sphecidae, Eumenidae, Pompilidae), and their natural enemies (Apoidea, Braconidae, Chrysididae, Chalcidoidae, Dermestidae, Eulophidae, Ichneumonidae, Pompilidae, Tachinidae) reared from trap nests. The names of natural enemies are given in Table 3.

\begin{tabular}{|c|c|c|c|c|c|}
\hline Species & $\begin{array}{l}\text { No. of } \\
\text { brood } \\
\text { cells }\end{array}$ & $\begin{array}{c}\text { Colonized } \\
\text { sites } \\
\text { (of 24) } \\
\end{array}$ & $\begin{array}{c}\text { Parasitism } \\
\text { and predation } \\
{[\%]} \\
\end{array}$ & $\begin{array}{c}\text { Unknown } \\
\text { mortality } \\
{[\%]}\end{array}$ & $\begin{array}{c}\text { Natural enemies } \\
\text { (numbers in } \\
\text { Table 3) }\end{array}$ \\
\hline Apoidea (Megachilidae) & & & & & \\
\hline $\begin{array}{l}\text { Chalicodoma (Callomegachile) } \\
\text { terminale }\end{array}$ & 120 & 12 & 1.67 & 6.67 & 6,22 \\
\hline $\begin{array}{l}\text { Chalicodoma (Callomegachile) } \\
\text { tuberculatum clotho }\end{array}$ & 12 & 4 & 8.33 & 50 & 22 \\
\hline $\begin{array}{l}\text { Halictus sp. } \\
\text { Heriades (Michenerella) sp. aff. }\end{array}$ & 12 & 2 & - & 50 & - \\
\hline fulvescens & 2,754 & 22 & - & 4.79 & - \\
\hline $\begin{array}{l}\text { Megachile (Paracella) sp. } \\
\text { Eumenidae }\end{array}$ & 165 & 13 & 0.61 & 14.54 & 10 \\
\hline Atherynchium fulvipenne & 1 & 1 & - & - & - \\
\hline $\begin{array}{l}\text { Epsilon manifestum } \\
\text { crassipunctatum }\end{array}$ & 21 & 4 & 4.76 & 4.76 & 4 \\
\hline Rhynchium atrum & 127 & 9 & 27.56 & 17.32 & $2,5,16,18,19,22$ \\
\hline $\begin{array}{l}\text { Rhynchium haemorrhoidale } \\
\text { umeroatrum }\end{array}$ & 2,326 & 24 & 18.14 & 20.94 & $\begin{array}{r}2,5,11,14,15,18 \\
19,20,21,22,24\end{array}$ \\
\hline Subancistrocerus clavicornis & 47 & 10 & 4.26 & 42.55 & 1,9 \\
\hline Zethus celebensis & 439 & 15 & 0.68 & 10.03 & 22 \\
\hline Pompilidae & & & & & \\
\hline $\begin{array}{l}\text { Auplopus levicarinatus } \\
\text { Sphecidae }\end{array}$ & 7,567 & 24 & 2.84 & 15.37 & $3,7,8,12,13,17,25$ \\
\hline Chalymbion bengalense & 7 & 2 & 28.57 & - & 23 \\
\hline Pison sp. & 19 & 5 & 5.26 & 36.84 & 5 \\
\hline
\end{tabular}


Table 2: Natural enemy species and the number of brood cells that were parasitised by the species in 24 agroforestry systems differing in light intensity and forest distance. The beetle species of the family Dermestidae is a predator. The two species of the family Tachinidae parasitised the food larvae of the wasps, therefore the wasp could not develop to adult.

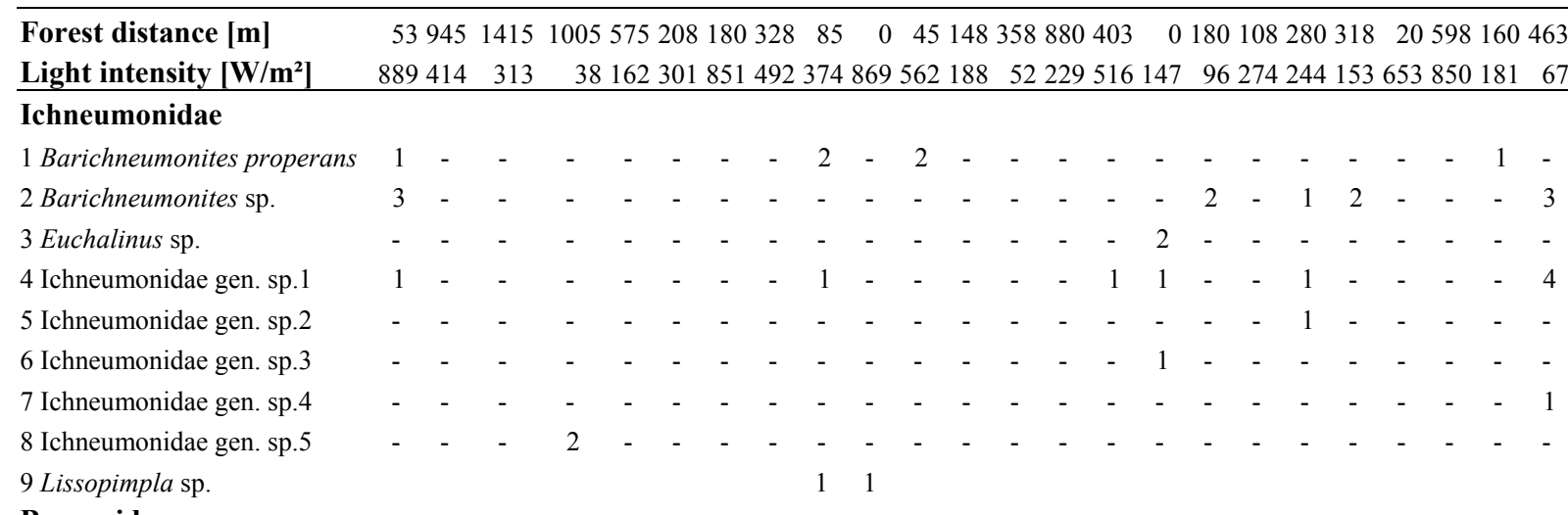

\section{Braconidae}

10 Braconidae gen. sp. 1

11 Braconidae gen. sp. 2

12 Braconidae gen. sp.3

\section{Chalcidoidae}

13 Chalcidoidae gen. sp. 1

14 Chalcidoidae gen. sp. 2

\section{Chrysididae}

15 Chrysis smaragdula

16 Chrysis sp. 1

17 Chrysis sp. 2

18 Chrysis sp. 3

19 Stilbum chrysochephalum

\section{Dermestidae}

20 Dermestidae gen. sp.

Megachilidae

21 Euaspsis wegneri

Pompilidae

22 Irenanglus punctipleuris

23 Irenanglus trifur

Tachinidae

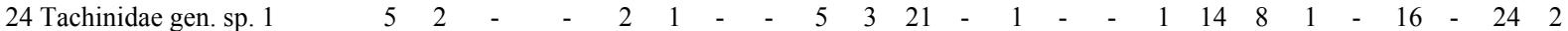

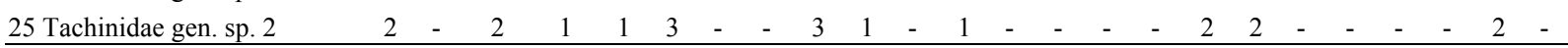

$\begin{array}{llllllllllllllllllllllll}39 & 9 & 17 & 17 & 22 & 12 & 28 & 5 & 36 & 73 & 56 & 29 & 8 & 12 & 18 & 26 & 41 & 41 & 14 & 23 & 47 & 6 & 49 & 54\end{array}$


A

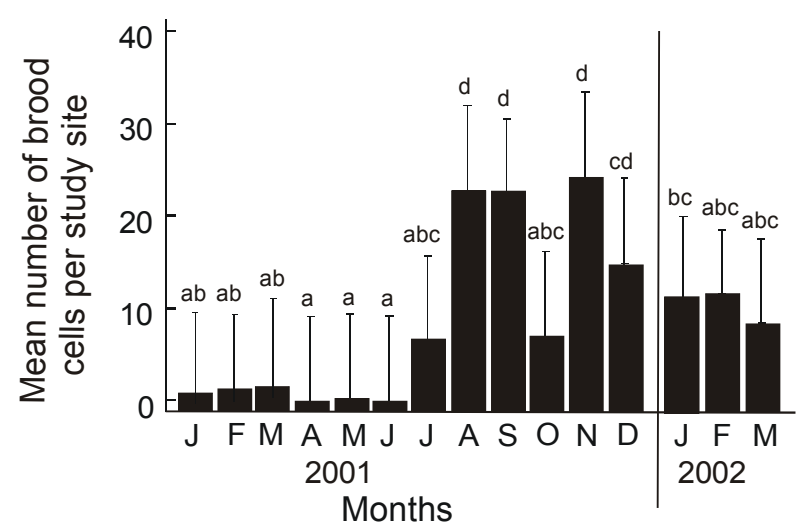

Fig. 1:

Mean number of brood cells, separated for bees and wasps, based on trap nests exposed in 24 agroforestry systems and a monthly sampling of occupied nests. Covariables: forest distance and light intensity:

A Bees: $F=5.62, p<0.001, d f=360$. Light intensity $(F=17.81, p<0.001, d f=1)$ was positively and forest distance $(F=12.40, p<$ $0.001, d f=1)$ negatively related.
B

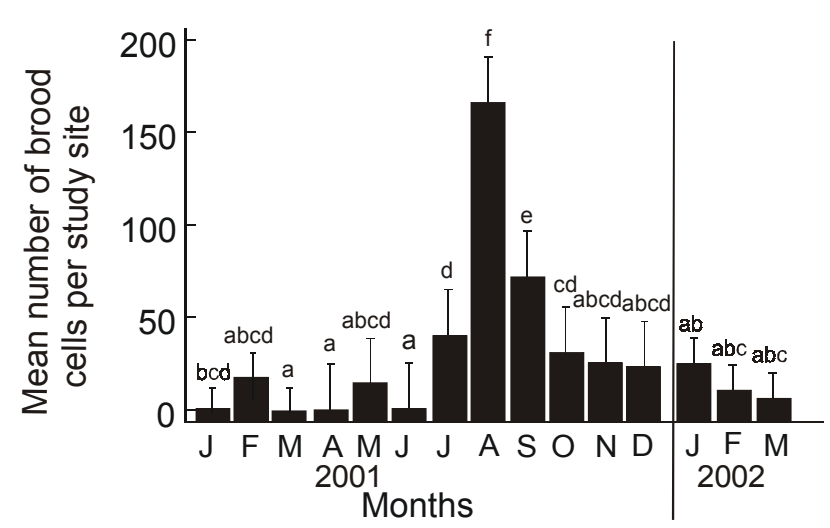

B Wasps: $F=19.49, p<0.001, d f=360$. Only light intensity had a further, negative effect $(F=10.09, p=$ $0.002, d f=1)$, but not forest distance $(F=1.38, p=$ $0.252, d f=1$ ). Arithmetic means and pooled standard errors are given. The same letters indicate homogenous groups at the $95 \%$ confidence level (Tukey HSD intervals).

\section{Effects of local and regional habitat parameters}

In stepwise multiple regressions with forest distance, light intensity, and number of plant species as predictor variables and the number of all trap-nesting species (excluding natural enemies) as the dependent variable, forest distance and light intensity explained most of the variation (Table 3, Fig. 2A). The number of wasp species showed the same tendency in the regressions, while the number of bee species was not related to any of the three independent variables (Table 3). The number of natural enemy species was even closer related to forest distance than its host, but not to light intensity, plant diversity or host density (Fig. 2B, Table 3). The number of all individuals was not related to the three habitat variables. The number of wasp individuals, however, decreased with light intensity, whereas the number of bee individuals increased with light intensity and decreased with forest distance (Table 3). The percentage of parasitised brood cells decreased with forest distance and was not related to light intensity, plant diversity or host density (Fig. 2C, Table 3).

Additionally, the percentage of brood cells parasitised of the three most abundant trapnesting species was tested for correlations to forest distance: only $R$. haemorrhoidale was correlated with forest distance $\left(F=11.87, r^{2}=0.32, n=24, p=0.002\right)$, but not $A$. levicarinatus $\left(F=0.20, r^{2}=0.09, n=24, p=0.659\right)$, and although $H$. fulvescens occupied 2.754 brood cells, no parasitoid or predator of this species was found. The negative relationship between wasp individuals and light intensity was based on the very abundant 
spider-hunting wasp species A. levicarinatus, which occupied more than $50 \%$ of all brood cells (Table 1). After dividing the wasp species into spider-hunting wasps (all species of the family Pompilidae and Sphecidae) and caterpillar-hunting wasps (all species of the family Eumenidae), we found that the number of spider-hunting wasp individuals was negatively correlated with light intensity $\left(F=8.40, r^{2}=0.276, n=24, p=0.008\right)$. The caterpillar-hunting wasp individuals showed no correlation with light intensity, and the species richness of caterpillar-hunting wasps even increased with light intensity of agroforestry systems $(F=$ 13.15, $\left.r^{2}=0.374, n=24, p=0.001\right)$. Consequently, these species determined the relationship between the number of all wasp species and light intensity (Table 3).

A

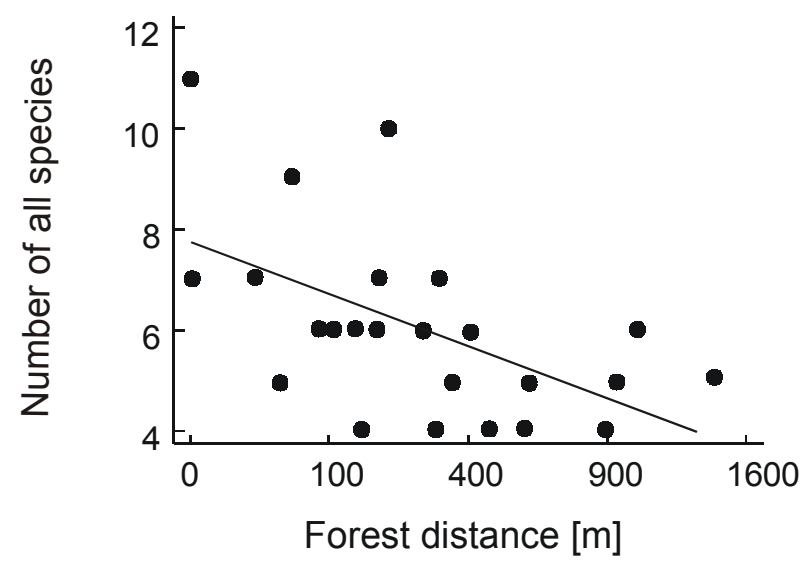

C

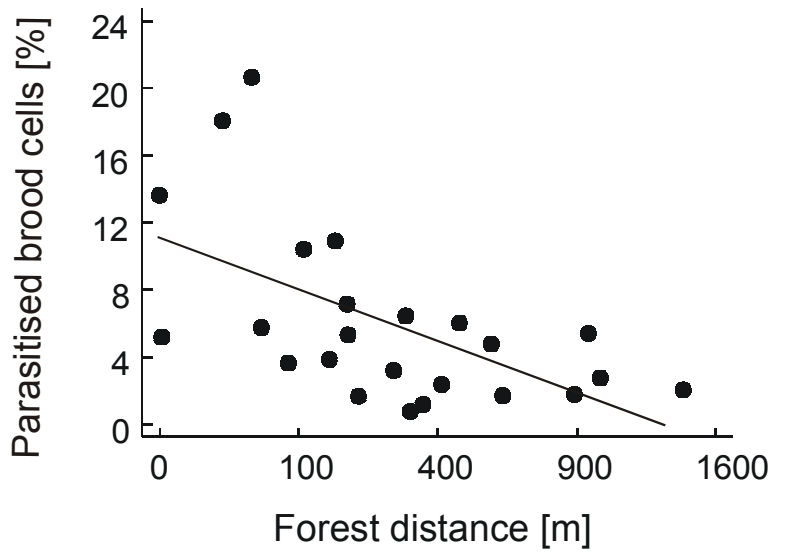

B

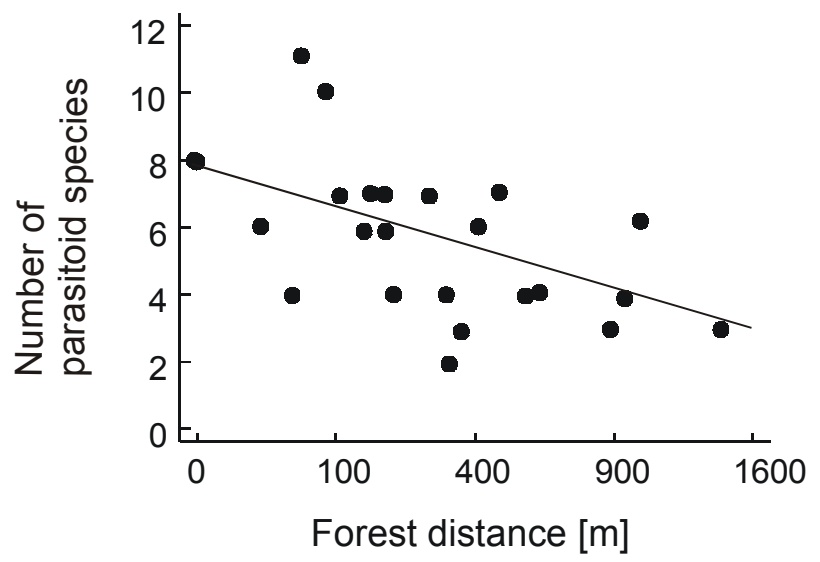

Fig. 2: Distance from the nearest natural forest in relation to

A: the number of all trap-nesting bee and wasp species per agroforestry systems.

B: the number parasitoid species per agroforestry systems

C: percent parasitised brood cells per agroforestry systems.

Statistics see table 3. 
Table 3: Results of stepwise multiple regression analyses of the three independent habitat factors, light intensity, forest distance, and number of plant species on species richness and abundance of bees and wasps, and bees and wasps separated of each other, and species richness of natural enemies and percentage parasitism including also the host density in the independent variables. Only significant results are shown.

\begin{tabular}{|c|c|c|c|c|}
\hline Dependent variables & Independent variables & $t$ Statistic & $p$-value & $r^{2}$ \\
\hline \multirow[t]{3}{*}{ Number of all species } & Forest distance $(\mathrm{m})$ & -2.45 & 0.023 & \\
\hline & Light intensity $\left(\mathrm{W} / \mathrm{m}^{2}\right)$ & 2.26 & 0.035 & \\
\hline & Final model & & & 0.348 \\
\hline \multirow[t]{3}{*}{ Number of wasp species } & Light intensity $\left(\mathrm{W} / \mathrm{m}^{2}\right)$ & 3.18 & 0.004 & \\
\hline & Forest distance (m) & -2.55 & 0.019 & \\
\hline & Final model & & & 0.537 \\
\hline Number of bee species & Final model & & & n.s. \\
\hline $\begin{array}{l}\text { Number of natural enemy } \\
\text { species }\end{array}$ & Forest distance & -3.42 & 0.002 & 0.347 \\
\hline Number of all individuals & Final model & & & n.s. \\
\hline Number of wasp individuals & Light intensity $\left(\mathrm{W} / \mathrm{m}^{2}\right)$ & -2.92 & 0.008 & 0.281 \\
\hline \multirow[t]{3}{*}{ Number of bee individuals } & Light intensity (W/m²) & 5.04 & $<0.001$ & \\
\hline & Forest distance $(\mathrm{m})$ & -2.27 & 0.034 & \\
\hline & Final model & & & 0.552 \\
\hline Percentage parasitism & Forest distance & -3.28 & 0.003 & 0.328 \\
\hline
\end{tabular}

\section{Discussion}

In this study we found, that the highest trophic level of the trap-nest community, the parasitoids, is more strongly affected by forest distance than are its hosts. This result includes the percentage parasitism as well as the species richness of natural enemies. Additionally, the local habitat factor light intensity affected the trap-nesting bees and wasps. Over one year, differences between the dry and rainy season could be only found for trap-nesting wasps, but not for bees.

To the best of our knowledge, this study provides for the first time data on the variable impact of higher trophic levels on bees and wasps, in a manner that is dependent on the local and regional management of tropical land-use systems.

\section{Isolation of agroforestry systems from natural forest}

The diversity of natural enemies (almost completely parasitoids) and percent parasitism decreased with forest distance, although host density was not related to the abundance of parasitoids. Theoretically, high host density could increase parasitism but on the other hand, high host densities may improve the protection against parasitoids and predators (Rosenheim 1990; Goodell 2003). Therefore, increasing host density does not always increase the abundance of parasitoids and predators. Moreover, the parasitoids as specialized natural enemies were more significantly affected by the isolation from natural forest than their hosts. 
In natural forests, higher trophic levels may build up large populations over a long period without disturbance. This supports the idea that higher trophic levels show a greater susceptibility to habitat disturbance and isolation (Kruess \& Tscharntke 1994, Tscharntke \& Kruess 1999, Holt et al. 1999, Steffan-Dewenter 2002). Accordingly, parasitoids should be generally more affected by isolation than predators, as they show greater host (or prey) specificity. In addition to resource specificity, the density of high trophic level populations is often lower and more variable than those of lower trophic levels (van Nouhuys \& Hanski 2002). Both rarity and population variability are well-known predictors of local extinction (Gaston 1994; Schoener \& Spiller 1992; Fagan et al. 2001), and trophic position, rarity, and population variability may be closely correlated (Kruess \& Tscharntke 1994).

In addition, the distance to the nearest species-rich grassland as a semi-natural habitat influenced natural enemy induced mortality of trap-nesting bees and wasps significantly, when traps were exposed in the cleared agricultural landscape at a large distance from the nearest species-rich grassland (Tscharntke et al. 1998). Forest fragmentation affects parasitoids such that outbreaks of the pest that are normally controlled by the parasitoids last longer in fragmented than in continuous forests (Roland \& Taylor 1995, 1997; Roland 2000). The number of wasp species, but not individuals, was negatively correlated with forest distance. The most abundant wasp species are probably adapted to open land-use systems and profit from the abundant food resource for their larvae inside the agroforestry systems (Klein et al. 2002b). Unlike wasps, the number of bee individuals, but not bee diversity, was affected by forest distance, probably due to the low species number of only five trap-nesting bee species. In contrast, moth species richness in tropical agricultural landscapes has been shown to decrease with increasing distance to natural forest (Ricketts et al. 2001), and diversity of coffee flower-visiting bees was negatively correlated with forest distance in the same agroforestry systems (Klein et al. 2003 in press a,b). Populations of trap-nesting bees and wasps mostly depend on the availability of dead wood for nesting sites, so colonization of the exposed traps should be enhanced by the presence of nearby old trees. Thus, an isolation experiment on meadows in Germany showed, that trap nests near isolated trees were colonized less than traps on orchards with many trees providing source populations (Tscharntke et al. 1998).

\section{Habitat management}

The number of natural enemy species and the percentage mortality caused by them were neither related to light intensity nor to the number of plant species, but both variables greatly 
decreased with increasing distance to the nearest forest. Wilby and Thomas (2002) showed with simulation models that increasing intensification in agroecosystems should generally decrease the natural enemy diversity, thereby supporting general expectations. In this study, the forests offered a wealth of nesting sites in an undisturbed environment, so populations of natural enemies can build up over many years, while the highly disturbed environment of agricultural land-use systems should generally inhibit the build up of populations of higher trophic levels (Tscharntke 2000, Klein et al. 2002a).

The number of wasp species was positively correlated with light intensity in the agroforestry systems, whereas the number of wasp individuals was negatively correlated with light intensity. Light inside the agroforestry systems should generally favour nesting activity, so early in the morning and during or shortly after rain the wasp species did not forage (A.M. Klein, personal observations). We found this negative correlation with light intensity, because numbers of the spider wasp A. levicarinatus, which inhabited more than $50 \%$ of all brood cells, decreased significantly with light intensity. The most important factor influencing the abundance of trap-nesting species is the availability of food for their larvae (Tscharntke et al. 1998). A. levicarinatus is a spider-hunting species and almost all spiders found in the nests belonged to the family Salticidae (jumping spiders). Spiders are more abundant in the shaded systems with dense trees and high structural diversity (Klein et al. 2002a), and the abundance of jumping spiders is generally related to the density of branches (Rinaldi and Sanches Rui 2002), which should be also negatively correlated with light intensity. The species-rich eumenid wasps are caterpillar-hunters and most of the caterpillars found in their nests feed on cacao leaves and are pests of this species. Some of the eumenid wasp species seem to be adapted to anthropogenic land-use systems and some species even nest inside human houses (see also Klein et al. 2002a). Eumenids often profit from increasing land-use intensity, which usually means increasing pest caterpillar populations, combined with high light intensity (Risch et al. 1983; van Emden 1990; Klein et al. 2002a; Wilby \& Thomas 2002).

The positive relationship between the number of bee individuals and light-intensity could be explained by the following reasons: (1) Light intensity is highly correlated with air temperature (see Klein et al. 2002a,b). Bees prefer to nest in warm and dry sites (Potts \& Willmer 1997), and the foraging activity of trap-nesting bees is higher in sites with high lightintensity (Klein et al. in preparation), and also on sunny days rather than rainy days or early in the morning (A.M. Klein, personal observations). (2) High light intensity favours the growth of herbs, offering flowers during the whole year, while perennial crops such as coffee flower only for a short while. Therefore, herbs are important pollen and nectar resources for the bees 
and, for example, the abundant megachilid bee H. fulvescens often foraged on a common herbaceous plant in the family Asteraceae (A.M. Klein, personal observations). In this study, the number of bee individuals was correlated with the number of herb species and the density of herbs, and also with light intensity. The species richness and abundance of trap-nesting bees are often closely related to plant species richness, because heterogeneous pollen and nectar resources usually attract a diverse community of flower-visitors (Tscharntke et al. 1998).

\section{Differences between dry and rainy season}

Plant phenology in tropical areas is generally known to depend on climatic conditions (Mori \& Prance 1987), and reproduction and life cycles of bees fit very well with resource conditions offered through pollen and nectar (Roubik 1989). There, we expect to find differences between the dry and rainy seasons for the bees and wasps. Unfortunately, we have no climate data from the study period in the Napu valley where the study took place. The rainy season in Sulawesi begins normally in October and ends in March with a peak in November/December. The dry season begins in April and ends in September with a peak in July/August (Knaus 1997). In July 2001 there was still high precipitation, but August 2001 was very dry with only some occasional rainfalls (A.M. Klein, personal observations). The wasps significantly established more brood cells in the dry than in the rainy season, but we did not find such seasonal differences for the bees. The wasps were more abundant in agroforestry systems than the bees (see also Klein et al. 2002a). Inside the agroforestry systems the number of bee brood cells was correlated with light intensity, so we expected to find higher bee abundance in the dry than in the rainy season. Possibly, insufficient bee brood cells were reared to find a seasonal effect for the bees. Further, observations for a complete year can sometimes indicate the seasonal activity of some bees and the identity of some of their resources, but they do not assess the variability determining the course of many interactions. Long-term studies of six to more successive years should be carried out to test results obtained during one-year observation period (Roubik 1989).

In conclusion, the trap-nesting bees and wasps were greatly affected by isolation from natural forest. Populations of their natural enemies, mostly specialised parasitoids, responded more sensitively to forest distance than their hosts, as could be expected from their higher trophic level. Within a 500m distance, the number of parasitoid species decreased from 8 to 5 , and percent parasitism from $12 \%$ to $4 \%$. With respect to local management, increasing light intensity favoured the number of bee individuals but decreased number of wasp individuals, 
because the most abundant spider-hunting species preferred to nest in the shaded and spiderrich systems. Enhancement of agroforestry diversity (of bees and wasps) and subsequent biological control could be best achieved through preservation of adjacent natural forests.

Acknowledgements Our special thanks go to Salma Andi Kaisang and Sudirman D.G. Massiri for the regular and careful laborious analyses of the trap nests. We are grateful to D. Buchori, V. Fuest, G. Gerold, D. Ratnadewi, E. Somba, and S. Werner of the German-Indonesian Research Project STORMA (Stability of Tropical Rainforest Margins) for their great support and help, and to J. Krauss and J. Tylianakis for helpful comments on the manuscript, to J. Gusenleitner (Eumenidae), M. Ohl (Sphecidae), K. Horstmann (Ichneumonidae), O. Niehuis (Chrysididae), R. Wahis (Pompilidae), and D.B. Baker (Megachilidae) for species identification, and to the Deutsche Akademische Austauschdienst (German Academic Exchange Programme) and the Deutsche Forschungsgemeinschaft (German Science Foundation) for financial support. 


\title{
6 FORAGING TRIP DURATION AND REPRODUCTIVE SUCCESS OF MEGACHILID BEES, EUMENID WASPS, AND POMPILID WASPS IN TROPICAL AGROFORESTRY SYSTEMS
}

\begin{abstract}
Most animals have to bridge some distances in space and time to provide all resources necessary for survival. Little is known how the local and regional management of tropical agroforestry systems, differing in the availability of food resources and suitable nesting sites, determine foraging trip duration and reproductive success of bees and wasps (Hymenoptera Aculeata). Foraging trip duration and brood-cell density (in trap nests exposed for a 15 months period) were analysed for three species, which represent three guilds, in 24 agroforestry systems in Central Sulawesi (Indonesia): the pollinator Heriades sp. aff. fulvescens (Apidae), the cacao caterpillar-hunting predator Rhynchium haemorrhoidale umeroatrum (Eumenidae), and the spider-hunting intraguild predator Auplopus levicarinatus (Pompilidae). The agroforestry systems were characterised by plant species richness, blossom cover of herbs, light intensity, and distance from the nearest natural forest.

The correlation of foraging time to reproductive success showed the relative importance of food and nest-site availability for the pollinator and the intraguild predator, because both parameters are correlated with light intensity in the agroforestry systems. In contrast, foraging time and nest density of the eumenid predator were not correlated, because of the distance between high quantities of food resources (in sites with dense cacao plants) and nesting sites (in adjacent natural forests). The eumenid response to local and regional agroforestry management illustrates that species may survive only in landscapes that permit access to multiple required resources. Accordingly, habitat evaluations using only foraging time may lead to wrong conclusions, as key drivers of population dynamics may not be inside, but outside the local systems, emphasizing the need of a landscape approach.
\end{abstract}

Keywords: landscape ecology, intraguild predation, bioindication, pollination, predation, trap nests 


\section{Introduction}

Most animals have to bridge some distances in space and time to provide all resources necessary for survival. Many birds forage in the open landscape but breed inside forests (Tworek 2002), butterfly adults search for nourishing flowers (Feber et al. 1996), but also for food plants suitable for their offspring (Thomas et al. 2001), and the host searching behaviour of adult parasitoids is determined by their food resources such as nectar (Patt et al. 1997, see also Bunce \& Howard 1990). Many species can survive only in landscapes that permit access to multiple required resources (Dunning et al. 1992).

The global change in habitat destruction and patterns of habitat fragmentation (Tilman et al. 2001) should especially affect species using multiple and spatio-temporally separated resources. In tropical landscapes, logging activities with high collateral damage or a conversion of rainforest to agroforestry and even non-shaded cropland is still increasing (Laurance 2000). In an era of such unprecedented land conversion, knowledge of the relative importance of land-use systems for conservation seems to be important, in particular for conservation of species depending on a certain spatial arrangement of habitat types. Traditionally managed agroforestry systems with several shade tree species may provide diversified resources, because of its near-natural complexity and plant diversity (Perfecto et al. 1996; Klein et al. in press a,b). In Central Sulawesi (Indonesia), the focus area of this study, crops are mostly managed in a traditional, diversified way, and in addition, landscapes are made up of land-use types such as agroforestry and more or less distant remnants of natural forest.

Habitats of bees and wasps must provide suitable nesting sites and food resources within their foraging range to ensure successful reproduction (Sutherland 1996; Westrich 1996; Strohm \& Mariliani 2002; Goodell 2003). In many cases, the foraging range of bees and wasps is not restricted to the direct neighbourhood of their nesting habitat, as also the surrounding landscape offers important additional sources of food plants and nesting sites. Steffan-Dewenter and Kuhn (2003) found larger foraging distances of pollen-collecting honeybees in simple than in complex landscapes. Honeybees are known to cover much larger foraging distances than solitary bees, but the latter are still not confined to small habitat patches (Steffan-Dewenter et al. 2002; Gathmann \& Tscharntke 2002) and are often important plant pollinators (Corbet et al. 1991; Vinson et al. 1993; Batra 1995). Above-ground nesting solitary species, which colonize trap nests, depend on holes of appropriate diameter left by wood-boring beetles and pithy or hollow plant stems of the correct diameter (Westrich 1996; Cane 2001). In addition, these species require resources for nest building such as mud, resins, 
pebbles, or plant hairs, which they use to line, partition, and plug their nests (O'Toole \& Raw 1991). The foraging trip distance can be indirectly measured with the foraging trip duration, to draw conclusions on the quality of the bees' and wasps' habitat (Gathmann \& Tscharntke 2002; Strohm et al. 2002). Prolonged searching for food or suitable nesting sites is an expensive activity in terms of time and energy, so that any behaviour that makes this process more efficient will be selected. Female bees often learn the position and habitat quality of their natal nest and return to that when founding their own nests (Jayasingh \& Freemann 1980; A.M. Klein, personal observations). This kind of limited dispersal behaviour is likely to evolve when there is a fitness advantage in selecting the most favourable nest sites in a habitat of high quality (Potts \& Willmer 1997).

The community of trap-nesting bees and wasps is known to contain species with different habitat demands (Tscharntke et al. 1998). Bees feed their larvae with pollen or nectar, whereas wasps feed their larvae with paralysed arthropods. Therefore, trap-nesting bees may provide seed set of allogamous plants due to successful pollination by bees, and biological control by predacious wasps (Tscharntke et al. 1998). For example, Ancistrocerus gazella, a trap-nesting eumenid wasp species, was found to control pest caterpillars in New Zealand (Harris 1994). Other trap-nesting wasps, such as sphecids or pompilids prey on spiders, so they are intraguild predators that may interfere with the potential control exhibited by their prey (Holt \& Pollis 1997; Borer 2002; Okuyama 2002).

The foraging trip duration and the successful reproduction in exposed trap nests were measured for 1) one bee species, that provides its larvae with pollen, 2) one eumenid wasp species, that provides its larvae with pest caterpillars feeding on cacao leaves, and 3) one pompilid wasp species that provides its larvae with spiders, thereby acting as an intraguild predator. Agroforestry systems, differing in light intensity, plant diversity, and distance from the nearest natural forest, were evaluated with these three trap-nesting hymenopterans. The following hypotheses were tested:

1. Foraging trip duration depends on the food availability of the agroforestry systems and its regional neighbourhood, i.e. the availability of adjacent natural rainforest.

2. Brood cell density is related not only to food but also to the availability of nesting sites, both determining overall reproduction success.

Data on foraging trip duration and successful reproduction of these bees and wasps may help to understand distribution patterns in species depending on multiple resources, which is a prerequisite in the development of conservation strategies for local and regional agroforestry management. 


\section{Materials and methods}

\section{Study region and systems}

The study was conducted from January 2001 to March 2002 in the vicinity of the Lore-Lindu National Park, in Central Sulawesi (Indonesia), approximately $100 \mathrm{~km}$ southeast from the city of Palu, in and around the villages of Wuasa, Watumaeta, Alitupo, and Kaduwaa in the Napu valley. Twenty-four agroforestry systems, dominated by coffee, but with different shade levels, vegetational, and structural complexity were studied. The light intensity (and therefore the shade ratio) per agroforestry system was measured with a luxmeter (digital light-gauge with four scopes from 0-1999 W/m²). Standardised conditions (on the ground, on sunny days, $9.00 \mathrm{am}-3.00 \mathrm{pm})$ were chosen and the mean of 20 measurements was calculated. The vegetation was mapped twice from January to September 2001 in each of the agroforestry systems, within a $25 \mathrm{~m}^{2}$-plot for herbs, and within a $100 \mathrm{~m}^{2}$-plot for shrubs and trees, resulting in estimates of the total number of plant species and the percentage of vegetation cover for every species. Percentage cover of flowering plants was recorded for each system to estimate the resource availability for the pollen-collecting bee species between July and September, at the same time as the foraging trip durations were measured. The agroforestry systems differed in their distance from the nearest natural forest (ranging from inside the forest margin, to a distance of $1,415 \mathrm{~m}$ from the nearest forest). We measured the distance from the forest with Global Positioning System (GPS 12 from Garmin International, Olathe, Kansas, USA).

\section{Trap nests}

Trap nests for Hymenoptera: Apidae, Sphecidae, Eumenidae, Pompilidae, and their enemies were set up in January 2001 and removed in March 2002. Ten trap nests for each of the 24 agroforestry systems were hung with a solid wire in coffee, cocoa, or shade trees (such as Erythrina sp. or Gliricidia sp.) at a height of $1.5 \mathrm{~m}$ to $2 \mathrm{~m}$. Sticky glue was put on each wire outside the trap nests to deter ants. The standardised traps consisted of about 120 internodes of a mixture of common reed Phragmites australis (Cav.) Trin. and Japanese knotweed Reynoutria japonica Houtt, cut to a length of $20 \mathrm{~cm}$ and inserted into plastic tubes of $10.5 \mathrm{~cm}$ diameter and a length of $25 \mathrm{~cm}$. The range of internal diameters of the reed or knotweed internodes varied between $2 \mathrm{~mm}$ and $20 \mathrm{~mm}$. One month after the traps were set up, we began to replace monthly all occupied internodes with unoccupied new internodes of a similar diameter. Nests were opened in the laboratory to make a preliminary identification of species and to establish the number of brood cells per species. 


\section{Foraging trip duration}

The three most common trap-nesting species, Heriades (Michenerella) sp. aff. fulvescens (Megachilidae), Rhynchium haemorrhoidale umeroatrum (Eumenidae), Auplopus levicarinatus (Pompilidae) had already used the trap nests in the first month after exposure (February 2001). From July to September 2001 we observed the foraging behaviour of these three species in all 24 agroforestry systems. The nest of each observed female was marked with acrylic colour. We measured with a stopwatch 1) the time an individual remained inside the nest between its arrival and departure for the next foraging trip ( $=$ the foraging trip duration or in the following text the term foraging time is used), and 2) the period between an individual leaving the nest until its subsequent return. The kind of material the individual collected was identified: a) caterpillars, spiders or pollen as food, b) nesting material such as soil, leaves, or wood resin to construct the nest. Additionally, every instance where an individual came back from the interior to the entrance was recorded. H. fulvescens often came back to the entrance shortly after entering to turn around and re-enter the nest backwards. When an enemy entered the nest, mostly while the host adult was outside, the time between arrival, departure, and re-entry were observed. Each of the three target species was observed at least for 10 arrival times per system. $R$. haemorrhoidale activity was observed in all $24, A$. levicarinatus in 23, and in 19 agroforestry systems. Because of low density, A. levicarinatus and $H$. fulvescens could not be observed during foraging in all 24 systems and $H$. fulvescens was even absent in some systems.

\section{Statistics}

We used mean foraging times of all individuals observed in each system to present the data. The data were analysed using the software 'Statgraphics Plus for Windows 3.0' (Manugistics 1997). All data were tested for normality and transformed if necessary. The independent variable 'forest distance' was always square root transformed to achieve normal distribution; all other variables were normally distributed (Sokal \& Rohlf 1995). Intercorrelations between the four independent habitat parameters forest distance, light intensity, blossom cover, and plant species richness were tested using a Pearson correlation matrix (Table 1). In stepwise multiple regression analyses with backward selection, we examined for each species the independent habitat factor that was most important for the foraging time. Light intensity and blossom cover were not used simultaneously because of their high intercorrelation. For the caterpillar-hunting species the percentage cacao cover was included in the analyses as a further habitat parameter, because the predated caterpillars were feeding on cacao leaves. 
Multiple regression analyses related the mean number of brood cells found in the 15 months for every of the three species to forest distance, light intensity, and plant species richness. We did not use blossom cover for the explanation of brood-cell density, because it was measured only during foraging observations and changed greatly between months because of the seasonal blooming periods of crop and non-crop plants. Arithmetic means \pm standard errors are presented.

Table 1: Pearson correlation matrix based on simple linear regression between habitat parameters. $* p<0.05$; ** $p<0.01 ; * * * p 0.001$.

\begin{tabular}{l|lll}
\hline & Forest distance $[\mathrm{m}]$ & Light intensity $\left[\mathrm{W} / \mathrm{m}^{2}\right]$ & Blossom cover [\%] \\
\hline Forest distance $[\mathrm{m}]$ & & & \\
Light intensity $\left[\mathrm{W} / \mathrm{m}^{2}\right]$ & -0.32 n.s. & $0.74 * * *$ & \\
Blossom cover $[\%]$ & -0.33 n.s. & $0.44 *$ & $0.42^{*}$ \\
Plant species richness & -0.46 n.s. & & \\
\hline
\end{tabular}

\section{Results}

Altogether, 240 trap nests (ten traps per each of the 24 agroforestry systems) resulted in 14 trap-nesting bee and wasp species with 13,617 individuals (Klein et al. in preparation). Ninety-three percent of all brood cells were occupied by the three species studied here: the bee Heriades (Michenerella) sp. aff. fulvescens (Megachilidae) was reared from 671 nests with 2,754 individuals, the eumenid wasp Rhynchium haemorrhoidale umeroatrum (Eumenidae) was reared from 849 nests with 2,326 individuals and the spider wasp Auplopus levicarinatus (Pompilidae) was reared from 2,348 nests with 7,567 individuals, respectively.

\section{Heriades (Michenerella) sp. aff. fulvescens}

Altogether, 107 pollen-collecting female individuals and a total of 415 foraging flights were observed. The bees needed more time to collect pollen or nectar as food for their larvae and for their own activity than for the collection of soil or wood resin to construct their nests. In most cases an individual bee entered the nest moving forward, turned back to the entrance, and re-entered moving backward. It is likely that the bee delivered the nectar first and then put the pollen off the ventral brush. The time an individual spent inside the nest after it entered moving forward was on average one and a half minute shorter than the time an individual spent inside the nest after it entered moving backward. The time spent inside the nest after entering with soil to build the partitions between brood cells was on average a half minute shorter than the time inside the nest after entering with wood resin to build partitions. Six individual parasitoids were observed, one individual of the family Chrysididae and five parasitoids of the family Ichneumonidae (Table 2). 
Table 2: Mean foraging times of the pollen-collecting bee $H$. fulvescens, the caterpillar-hunting wasp $R$. haemorrhoidaele, and the spider-hunting wasp A. levicarinatus. The mean trip duration for collecting different nesting material, and the number of parasitoids observed entering the nest are presented.

\begin{tabular}{|c|c|c|c|}
\hline & Heriades & Rhynchium & Auplopus \\
\hline Individuals observed with food & 107 & 109 & 105 \\
\hline Measurements of individuals observed with food & 415 & 278 & 286 \\
\hline Mean foraging time [min] & $2.68 \pm 0.11$ & $5.57 \pm 0.20$ & $3.82 \pm 0.35$ \\
\hline Mean time inside the nest after collection of food [min] & $1.98 \pm 0.14$ & $0.98 \pm 0.11$ & $1.27 \pm 0.09$ \\
\hline Individuals observed with soil & 11 & 31 & 16 \\
\hline Measurements of individuals observed with soil & 49 & 105 & 31 \\
\hline Mean time collecting soil [min] & $1.30 \pm 0.24$ & $1.68 \pm 0.21$ & $1.86 \pm 0.47$ \\
\hline Mean time inside the nest after collection of soil [min] & $0.52 \pm 0.08$ & $2.25 \pm 0.35$ & $0.92 \pm 0.12$ \\
\hline Individuals observed with wood resin & 16 & - & 40 \\
\hline Measurements of indiv. observed with wood resin & 59 & - & 136 \\
\hline Mean time collecting wood resin [min] & $1.80 \pm 0.21$ & - & $2.60 \pm 0.27$ \\
\hline Mean time inside the nest after collection of wood resin [min] & $1.53 \pm 0.20$ & - & $1.42 \pm 0.14$ \\
\hline Individuals observed with other building materials & - & - & 6 \\
\hline Measurements of indiv. observed with other material & - & - & 25 \\
\hline Mean time collecting other materials [min] & - & - & $0.88 \pm 0.18$ \\
\hline Mean time inside the nest after collection of other material [min] & - & - & $0.47 \pm 0.07$ \\
\hline Mean value turn up pollen $[\mathrm{min}]$ & $0.40 \pm 0.13$ & - & - \\
\hline Individuals of Chrysididae as a parasitoid & 1 & 13 & 17 \\
\hline Measurements of number of Chrysididae & 1 & 34 & 48 \\
\hline Mean value Chrysididae staying inside the nest [min] & $0.09 \pm 0.00$ & $2.47 \pm 0.11$ & $0.90 \pm 0.15$ \\
\hline Individuals of Ichneumonidae as parasitoids & 5 & 3 & 1 \\
\hline Measurements of number of Ichneumonidae & 6 & 5 & 1 \\
\hline
\end{tabular}

The foraging time was tested in multiple regressions with the habitat factors forest distance, plant species richness, blossom cover and light intensity as a separate variable. The foraging time decreased with increasing blossom cover (Fig. 1A), and with increasing light intensity of the agroforestry systems (Fig. 1B). The bee species primarily foraged on a common species of Asteraceae inside the systems, but also foraged on coffee plants when they were flowering. Neither the plant species richness, nor the forest distance were correlated with the foraging time. The mean number of brood cells reared in altogether 15 months per system was also positively correlated with light intensity (Fig. 1C), but neither with forest distance, nor plant diversity. The number of brood cells was negatively related to the foraging time, but only with marginal significance $\left(r^{2}=0.17, n=19, p=0.08\right)$. 
A
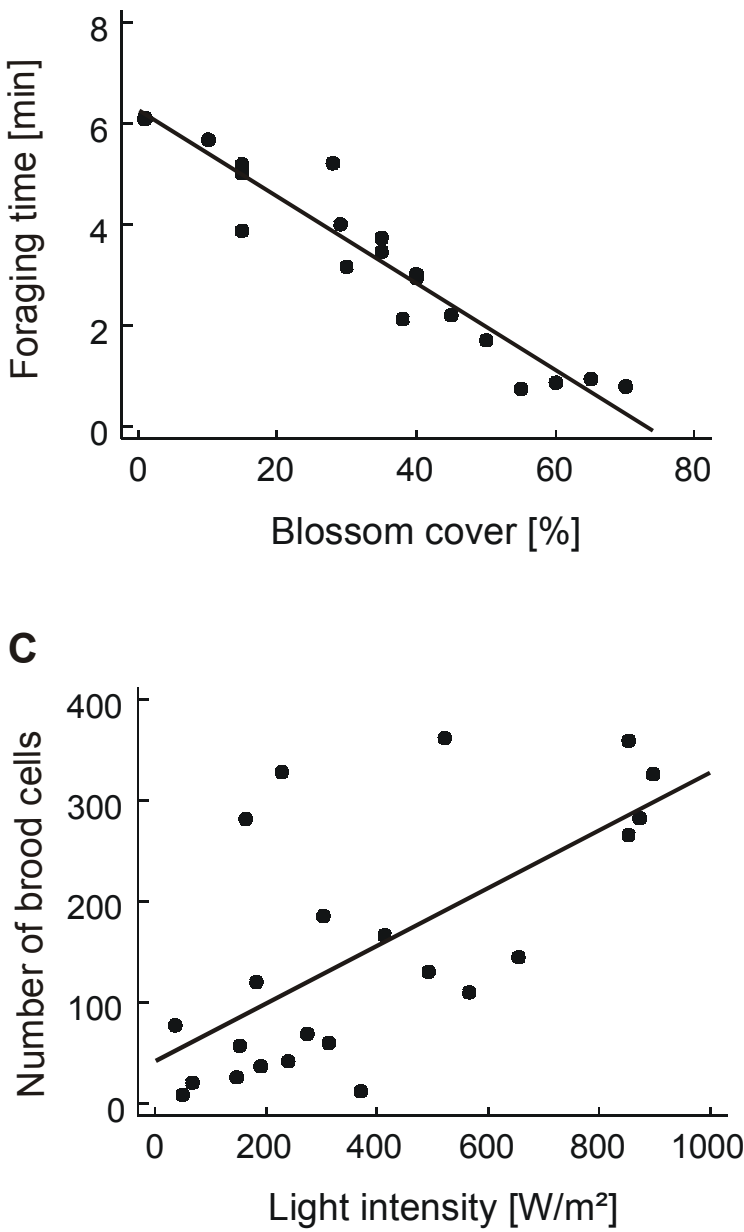

B

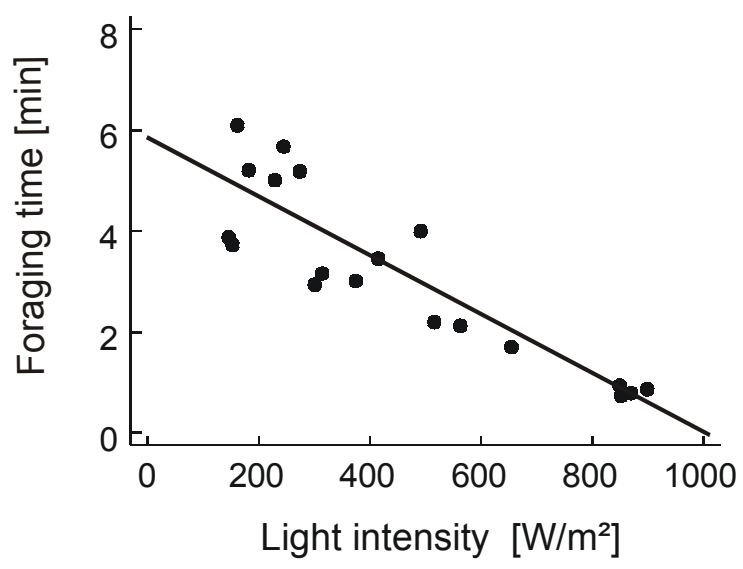

Fig. 1:

A: Relationship between the foraging time of $H$. fulvescens and the blossom cover: $y=6.24-0.09 x, r^{2}$ $=0.89, n=19, p<0.001$.

B: Relationship between the foraging time of $H$. fulvescens and the light intensity: $y=5.71-0.01 x, r^{2}$ $=0.79, n=19, p<0.001$.

C: Relationship between the number of brood cells of H. fulvescens and the light intensity: $y=41.03+$ $0.29 x, r^{2}=0.42, n=23, p<0.001$.

\section{Rhynchium haemorrhoidale umeroatrum (Eumenidae)}

Altogether, 109 caterpillar-hunting female individuals and a total of 278 foraging flights were observed. The wasps needed around four minutes more for collecting caterpillars than for collection of soil for nest building. The wasps normally entered the nest moving forward and left it also forward. Sometimes the internodes appeared to be too small for turning inside the nest, so the wasp left backward. The time spent inside the nest after entering with caterpillars was around one and a half minute shorter than the time inside the nest after the wasp entered with soil to build the partitions between brood cells. We observed 13 parasitoid individuals of the family Chrysididae and three of the family Ichneumonidae (Table 1).

The foraging time was tested in multiple regression analyses with forest distance, plant species richness, blossom cover, and separately with light intensity. The percentage cacao cover was also included in the analyses, because the predated caterpillars were feeding on cacao leaves. Foraging time decreased significantly with increasing cacao cover of the agroforestry systems (Fig. 2A). Forest distance, plant species richness, blossom cover, and 
light intensity were not significantly correlated with foraging time. Excluding four agroforestry systems that had no cacao plants, the foraging time decreased with increasing light-intensity (Fig. 2B), and with blossom cover of the agroforestry systems $\left(r^{2}=0.21, n=\right.$ 20, $p=0.043)$. The mean number of brood cells reared in 15 months decreased with increasing forest distance (Fig. 2C), and was not related to light intensity and plant diversity. We did not find a correlation between the number of brood cells and the foraging time $\left(r^{2}=\right.$ $0.03, n=19, p=0.401)$.

A

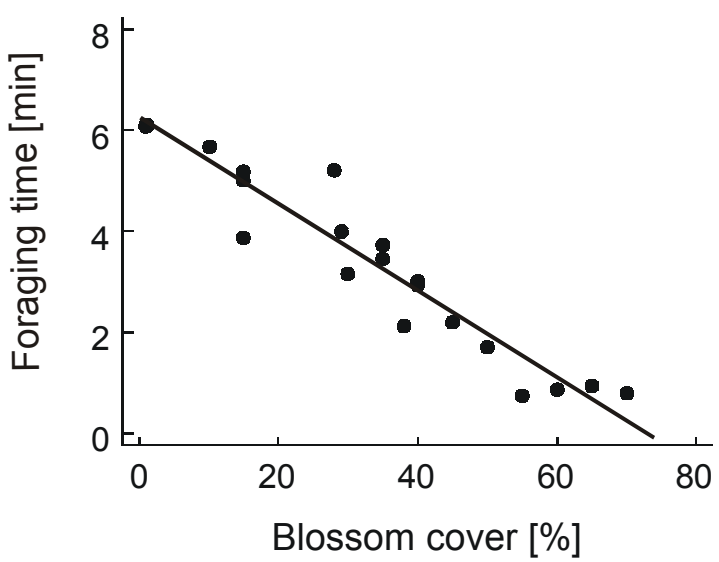

C

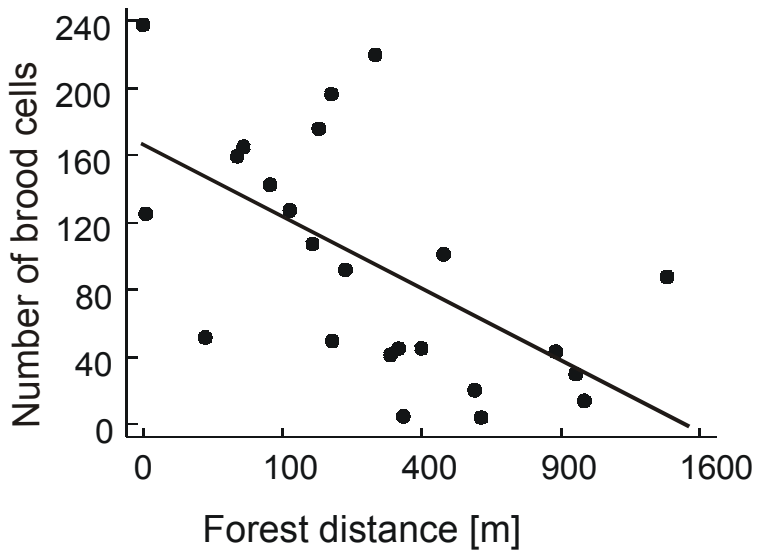

B

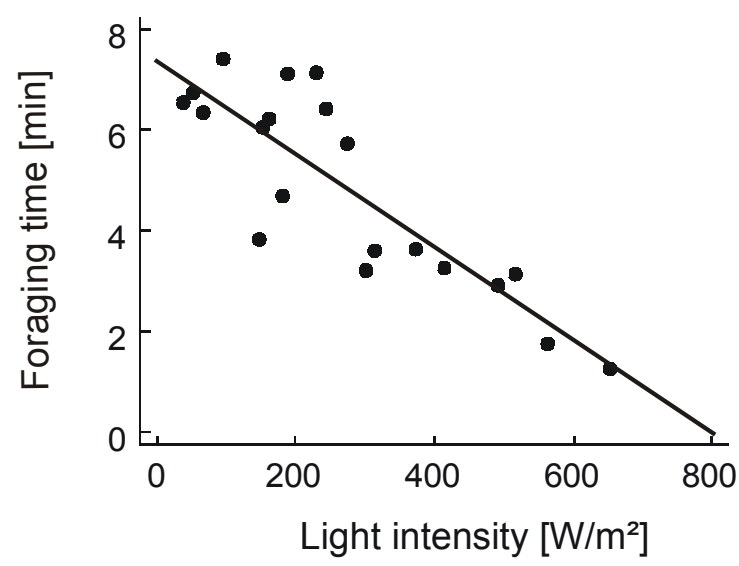

Fig. 2:

A: Relationship between the foraging time of $R$. haemorrhoidale and the cacao cover: $y=6.67-0.06 x$, $r^{2}=0.21, n=24, p=0.022$.

B: Relationship between the foraging time of $R$. haemorrhoidale and the light intensity (excluding agroforestry systems without intercropped cacao plants): $y=7.37-0.01 x, r^{2}=0.74, n=20, p<0.001$.

C: Relationship between the number of brood cells of R. haemorrhoidale and the forest distance: $y=165.77$ $-4.24 \sqrt{ } x, r^{2}=0.36, n=23, p=0.002$.

\section{Auplopus levicarinatus (Pompilidae)}

Altogether, 105 female pompilids and a total of 286 foraging flights were observed. On average, this wasp species needed two more minutes for spider collection than for the collection of soil. The collection of wood resin was only around one minute faster than the spider collection. Very fast was the collection of other materials, most of them were remains of empty internodes that were already occupied by other individuals and species. This includes dry soil, leaves, reed or knotweed remainders, dead spiders, caterpillars or larvae. 
The wasps normally entered the nest moving forward and also left it forward. As described for the caterpillar-hunting wasps, this species sometimes left backward when the internodes were too small for turning inside the nest. The time this species spent inside the nest after entering with spiders was on average a half minute longer than the time inside the nest after entering with soil for building partitions, and this was around a half minute longer than the time spend inside the nest after entering the nest with other materials such as remains of empty internodes.

Seventeen parasitoid individuals of the family Chrysididae and only one parasitoid of the family Ichneumonidae were observed (Table 1). In multiple regression analyses with forest distance, plant species richness, blossom cover, and light intensity as a separate variable, the foraging time increased significantly with increasing light intensity (Fig. 3), and increasing forest distance $\left(r^{2}=0.18, n=23, p=0.045\right)$. Plant species richness and blossom cover were not correlated with foraging time. The mean number of brood cells reared in altogether 15 months per system decreased with increasing light intensity (Fig. 3B), but was not related to plant diversity and forest distance. The number of brood cells was negatively correlated with the foraging time $\left(r^{2}=0.18, n=23, p=0.037\right)$.

A

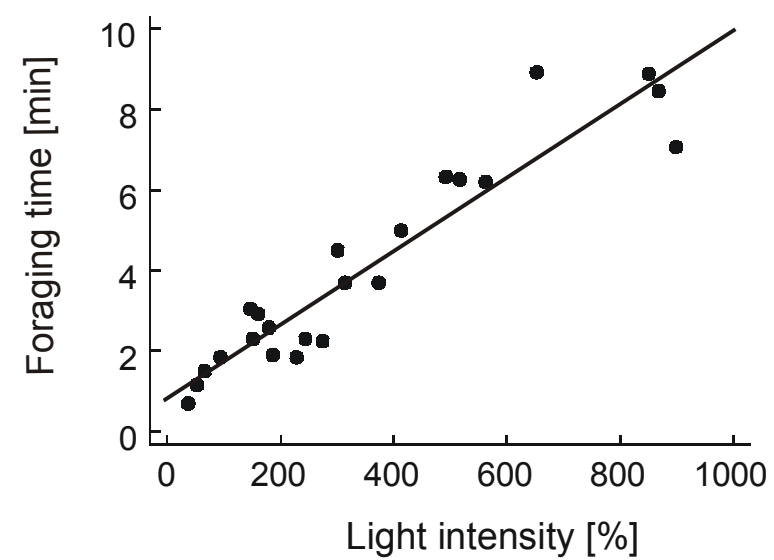

Fig. 3A: Relationship between the foraging time of $A$. levicarinatus and the light intensity: $y=0.86+0.01 x$, $r^{2}=0.88, n=23, p<0.001$.

\section{B}

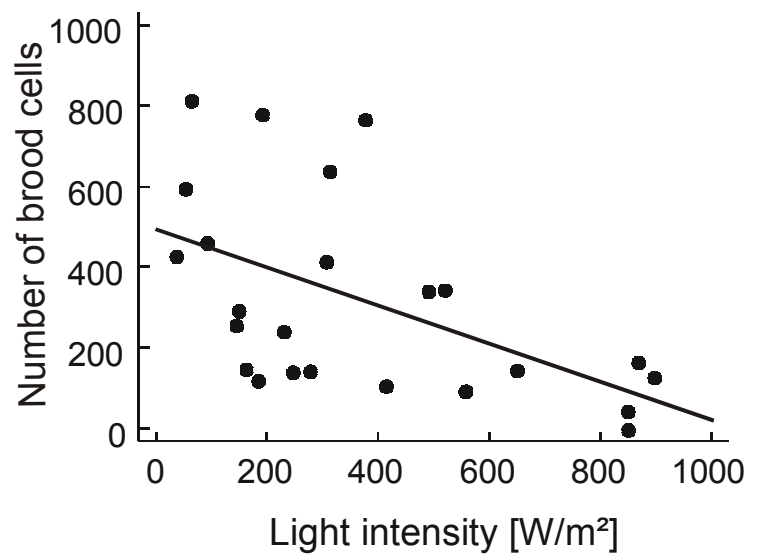

Fig. 3B: Relationship between the number of brood cells of $A$. levicarinatus and the light intensity: $y=$ $489.96-0.47 x, r^{2}=0.28, n=24, p=0.007$.

\section{Discussion}

In a comparison of the foraging time and reproductive success of three trap-nesting species from three ecological guilds (pollinator, predator of pests, and intraguild predator) light intensity, blossom cover, and distance from the nearest natural forest turned out to be 
important characteristics of the studied agroforestry systems. As expected, foraging time of all species appeared to be strongly determined by the availability of food for their offspring.

The foraging time of the pollen-collecting bee species $H$. fulvescens was negatively correlated with the blossom cover of flowering plants and light intensity of agroforestry systems. This is in support of the expectation that two major factors determine foraging behaviour and activity patterns in nectar and pollen foraging insects: First, microclimatic conditions influence the foraging behaviour and activity of bees (Corbet et al. 1993; Stone 1994; Stone et al. 1999; Bosch \& Kemp 2002). In the morning and on cloudy days, individuals of $H$. fulvescens rested in the entrance of their nest. As soon as the sunlight reached their nest, the bees began to forage pollen and nectar for their larvae and themselves (A.M. Klein, personal observations). Similarly, the nesting activity of Osmia rufa is also determined by temperature (Strohm et al. 2002). The second factor determining foraging behaviour of nectar and pollen collecting insects is the quality and quantity of floral rewards available, including sugars, amino acids and water (Corbet et al. 1993; Stone 1994). In the first nine months after traps were set up the bee $H$. fulvescens nested only in 19 out of 24 agroforestry systems, and these five systems, which were colonized with few brood cells later on, were too shaded, meaning few flowering plants, and therefore too wet, meaning less suitable nesting conditions because of high humidity inside the nests. Flowering plants can be used as a surrogate for pollen and nectar resource availability (Tscharntke et al. 1998). Klein et al. (in press $a, b$ ) found a similar pattern with respect to coffee flower-visiting solitary bees in that a reduction of shade and a high weed density provide more nectar and pollen resources and thereby increase coffee yield.

The duration of foraging trips by the caterpillar-hunting eumenid wasp $R$. haemorrhoidale decreased with increasing cacao cover of the agroforestry systems. The arctiid caterpillars found in trap nests were cacao leaf-feeding pests. The foraging time of this wasp was related only to the cacao cover per agroforestry system. However, when the four agroforestry systems without cacao plants were excluded, the foraging time of this wasp was positively correlated with light intensity and blossom cover. For this cacao caterpillar-hunting species, food abundance for their offspring appeared to be the most important factor limiting foraging time.

Foraging time of the spider-hunting pompilid wasp A. levicarinatus increased with increasing light intensity. This is in contrast to the general expectation that insect activity profits from sunlight. The preference of shade was not due to a generally higher activity early in the morning or whilst it was raining or shortly after rain (A.M. Klein, personal 
observations). However, the decreasing foraging time and decreasing brood-cell density of these pompilids with increasing light intensity could be explained by food availability in the agroforestry systems. Almost all spiders found in their nests belong to the spider family Salticidae. In a former study, Klein et al. (2002b) found an increase of spider densities with decreasing light intensity.

Many insect communities are known to be influenced by not only the local habitat conditions, but also by the surrounding landscape matrix (Huston 1999; Perfecto \& Vandermeer 2001; Ricketts 2001; Steffan-Dewenter 2002; Tscharntke et al. 2002a,b). Such a regional effect has also been shown for trap-nesting species (Tscharntke et al. 1998; SteffanDewenter 2002; Steffan-Dewenter in press; Klein, unpublished data). This study shows that foraging time as well as reproductive success of the bee was positively influenced by light intensity, so foraging time was a (marginal significant) predictor of the number of brood cells per site. In contrast, the foraging time and the number of brood cells of the spider-hunting pompilid wasp were even negatively related to light intensity, because the spider prey of this intraguild predator was most abundant in shaded systems and both foraging and nesting success were related. The distribution pattern of the cacao caterpillar-hunting eumenid wasp showed that foraging time and reproductive success may be little related, because foraging time was related to cacao cover, while the number of brood cells declined with distance from the nearest forest. This eumenid species appeared to mainly depend on the wealth of nesting sites in undisturbed forests, so only the successful colonizers of cacao-rich systems profited from the great food supply, resulting in an overall independence of foraging time and number of brood cells. This indicates a possible trade off between suitable nesting sites and food availability for the larvae.

Furthermore, the body size of the eumenid wasp was greater than that of the two other species. Foraging distance of bees is known to increase with increasing body length (vanNieuwstadt \& Iraheta 1996; Gathmann \& Tscharntke 2002), and body size appeared to be a good predictor of colonization ability in trap-nesting species (Gathmann et al. 1994). Because of these size differences, the eumenid wasp could bridge longer distances between forest with suitable nesting sites and land-use systems with suitable food resources. This is indicated by a) the dependence of the number of brood cells on forest distance and b) the longer foraging time of this species compared to the other two species.

The duration of foraging trips of all three species was on average rather short. Gathman \& Tscharntke (2002) examined the foraging time of eight trap-nesting bee species in Germany. The fastest bee species need on average 6 min and the slowest species $33 \mathrm{~min}$ for 
one foraging trip. Strohm et al. (2002) found about $13 \mathrm{~min}$ for one foraging trip of the megachilid bee Osmia rufa L. in Germany. This temperate-tropical difference may be due to the higher temperature and the higher food availability in our tropical systems. Strohm et al. (2002) found that females needed about three quarters of the total time for a brood cell to forage for pollen and nectar whereas construction of cell partitions was comparatively rapid. For the bee species in this study, the mean time spent collecting material for cell construction was about $1.55 \mathrm{~min}$, whereas an average of $2.68 \mathrm{~min}$ was spent foraging for pollen. The relatively small difference between these values and the fast foraging time in general indicate that the agroforestry systems in which the bee nests provide a great amount of attractive pollen, in particular of one all-year flowering Asteraceae species.

In conclusion, the foraging time and reproductive success of trap-nesting species shows the relative importance of food and nest-site availability for the performance of a bee pollinator, an eumenid predator of pest caterpillars and a spider-hunting and, thereby, intraguild predator belonging to the Pompilidae. Brood-cell density and foraging time were only correlated in the pollinator and in the intraguild predator, but not in the eumenid predator, because of a trade off between high quantities of food resources (in sites with dense cacao plants) and nesting sites (in adjacent natural forests). The eumenid predator response to local and regional agroforestry management illustrates that species may survive only in landscapes that permit access to multiple required resources. Accordingly, habitat evaluation using only foraging time may lead to wrong conclusions, as key drivers of population dynamics may be not inside, but outside the local systems, emphasizing the need of a landscape approach.

Acknowledgements Our special thanks go to Salma Andi Kaisang and Sudirman D.G. Massiri for the regular careful and laborious analyses of the trap nests, and for the observation of the trap-nesting species. Further help in the field came from Ecil Tamalagi, Pille and friends. We are grateful to D. Buchori, V. Fuest, G. Gerold, D. Ratnadewi, E. Somba, and S. Werner of the German-Indonesian Research Project STORMA (Stability of Tropical Rainforest Margins) for their great support and help, and to Jason Tylianakis and Jochen Krauss for helpful comments on the manuscript, to J. Gusenleitner (Eumenidae), J. Wahis (Pompilidae), and D.B. Baker (Megachilidae) for species identification, and to the Deutsche Akademische Austauschdienst (German Academic Exchange Programme) and the Deutsche Forschungsgemeinschaft (German Science Foundation) for financial support. 


\section{Zusammenfassung}

Agrarökosysteme dominieren die heutigen tropischen Landschaften, Waldrelikte sind nur noch vereinzelt in die Kulturlandschaft eingestreut. Die meisten Insektenarten, die in den verbliebenen Regenwäldern und deren Fragmenten überleben, interagieren mit diesen Landnutzungssystemen. Wenige Untersuchungen zeigen, dass einige Bienen- und Wespenarten sogar von der Landnutzung profitieren können. Somit wird der potentielle Wert vor allem der traditionellen Landnutzung übersehen. Nicht nur die lokalen Landnutzungsmerkmale, sondern auch die Entfernung zum naturnahen Habitat spielen eine wichtige Rolle für das Überleben gefährdeter Arten.

Über den Einfluss der lokalen und regionalen tropischen Landnutzung auf die PflanzeBestäuber-, Räuber-Beute- und Wirt-Parasitoid- Interaktionen ist bis heute sehr wenig bekannt.

In 24 Agroforstsystemen, die sich in ihrer Beschattung, Pflanzendiversität und Entfernung zum Regenwald unterscheiden, wurde untersucht, inwieweit diese Habitatfaktoren einen Einfluss auf die Bienen- und Wespenlebensgemeinschaften und ihre ökologischen Funktionen haben.

Im ersten Teil der Arbeit wurde zunächst die Bestäubungsbiologie des Hoch- und Tieflandkaffees untersucht. Die Ergebnisse geben eindeutige Hinweise, dass sowohl die selbststerile als auch die selbstfertile Kaffeeart von der Bestäubungsleistung durch Bienen beeinflusst wurden. In einem zweiten Schritt wurden die Folgen der lokalen und regionalen Landnutzung für die Bienenlebensgemeinschaft und ihre Bestäubungsleistung gezeigt. Die solitären Bienen wurden durch geringere Beschattung der Agroforstsysteme gefördert. Die sozialen Bienen zeigten eine positive Beeinflussung durch die unmittelbare Nähe zum Regenwald. Die Gründe sind in den unterschiedlichen Nistplatzansprüchen dieser beiden Gruppen zu finden: Soziale Bienen in der Untersuchungsregion nisten in hohen Bäumen und im Todholz. Die meisten solitären Bienenarten nisten im Boden (endogäisch). Der positive Einfluss eines vermehrten Nistplantzangebotes für die Bienenlebensgemeinschaft spiegelte sich auch in der Bestäubungsleistung von Kaffee durch einen erhöhten Fruchtansatz wider. Beide Kaffeearten zeigten einen engen Zusammenhang zwischen Diversität und Fruchtansatz. Bei C. arabica galt dieser Zusammenhang für die Diversität, nicht aber für die Häufigkeit der Bienen. Damit liefert diese Arbeit einen wichtigen Beitrag zu der allgemeinen Diskussion über den Zusammenhang zwischen Artenvielfalt und ökologischen Funktionen. 
Im zweiten Teil der Arbeit wurden in den gleichen Flächen die Diversität und Häufigkeit von nisthilfenbewohnenden Bienen und Wespen, die Interaktionen mit ihren natürlichen Gegenspielern (Wirt-Parasitoid) sowie die Interaktionen mit ihrer Beute, die sie für ihre Larven in die Nester eintragen (Räuber-Beute), untersucht. Sowohl die Diversität der nisthilfenbewohnenden Bienen und Wespen als auch die Diversität ihrer Gegenspieler nahm mit zunehmender Entfernung vom Regenwaldrand ab. Dabei konnte gezeigt werden, dass die höchste trophische Ebene, die der Parasitoide, am stärksten beeinflusst wurde. Auch die Parasitierungsrate nahm mit zunehmender Entfernung vom Regenwaldrand ab. Diese Ergebnisse zeigen, dass höhere trophische Ebenen sehr sensibel auf Umweltveränderungen reagieren und geben einen Hinweis auf eine erhöhte biologische Schädlingsbekämpfung in regenwaldnahen Agrarökosystemen.

Die Bienen- und Wespendichte variierte stark zwischen den Monaten. Wespen waren signifikant häufiger in der Trockenzeit im Gegensatz zur Regenzeit. Dieser Zusammenhang konnte allerdings nicht für die Bienen gezeigt werden.

Anhand von Messungen der Sammelflugzeiten dreier Arten wurde die Qualität der 24 Agroforstsysteme für Bienen und Wespen untersucht. Das Experiment zeigte, dass die Sammelflugzeiten stark mit der jeweiligen Ressourcenverfügbarkeit (Larvenproviant) korreliert waren, aber auch die Lichtintensität zeigte signifikante Zusammenhänge. Die Sammelflugzeiten verkürzten sich allerdings nicht signifikant mit zunehmender Waldrandnähe. Nur die Brutzellenanzahl einer Wespe nahm mit zunehmender Entfernung zum Regenwald ab. Die Sammelzeit zeigte nur bei zwei von drei Arten einen direkten Zusammenhang mit der Nistplatzwahl. Somit war die Nistplatzwahl nicht zwingend von der Ressourcenverfügbarkeit abhängig. Zudem können sich einige Arten nur optimal reproduzieren, wenn verschiedene Habitattypen (offene Landschaften, Regenwald) in ihrem Aktionsradius vorkommen, die in ihrer Gesamtheit alle benötigten Ressourcen abdecken.

Alle Hauptergebnisse führen zu folgenden Schlussfolgerungen und Maßnahmen, um ,freie' ökologische Leistungen wie Bestäubung, Prädation und Parasitierung und den damit verbundenen ökonomischen Wert der traditionellen Agroforstsysteme zu sichern:

1. Der intakte Regenwald und Regenwaldreste in der Nähe von Agroforstsystemen sollten hohe Schutzpriorität bekommen, damit soziale Bienen, Gegenspieler von Schädlingen und Parasitoide in die Agrarökosysteme einfliegen können.

2. Eine rechtzeitige Auflichtung der Agroforstsysteme und ein reichhaltiges Blütenangebot fördern Bienen und Wespen, indem ein optimales Mikroklima und Nistplätze für bodennistende Bienen und Wespen geschaffen werden. 


\section{Summary}

Tropical landscapes are dominated by agroecosystems and most species that survive in forest remnants interact with these agroecosystems. However, few studies show that some species even profit from land use, thus the potential value of land-use systems for species survival is often overlooked. In addition to the features of the local habitat, distance to the natural habitat is also of major importance. Little knowledge about the influence of local and regional tropical land use on the plant-pollinator-, predator-prey-, and host-parasitoid-interactions exists.

In a comparison of 24 agroforestry systems, which differ in terms of plant species richness, light intensity, and distance to the nearest natural forest, the effects of local and regional land use on bee- and wasp-communities and their ecological services are examined.

The first part of the thesis describes the differences in pollination biology between the highland and the lowland coffee. The results give clear evidence for highest fruit set in the self-sterile and the self-fertile coffee species after bee pollination in contrast to fruit set after wind- or self-pollination. Furthermore, the consequences of local and regional land use on the bee community and their pollination success are shown. Pollinator diversity was affected by two habitat parameters indicating guild-specific nesting requirements: the diversity of solitary bees increased with increasing light intensity of the agroforestry systems, whereas the diversity of social bees decreased with increasing forest distance. These results reflect the pollination success on coffee with higher fruit set in agroforestry systems, which provide sunlight and are located closest to the forest. Both coffee species showed relations between pollinator diversity and fruit set. In C. arabica only the diversity, but not the abundance explained variation in fruit set. This result gives therefore an important contribution to the diversity-function discussion.

The second part of the thesis analyses the diversity and abundance of trap-nesting bees, wasps, and their interactions with natural enemies (host-parasitoid), and the interactions with food resources, that are used for the larvae inside the trap nests (predator-prey). Both bee and wasp diversity were negatively affected by increasing forest distance but increased with light intensity of the agroforestry systems. The highest trophic level (diversity of parasitoids, and percentage parasitism) showed even a stronger relationship with forest distance than their host did. These results show that first, higher trophic levels are more affected from environmental changes such as isolation from natural habitats and second, agroecosystems close to natural forest should be more efficient in the natural control of pest insects. 
The density of the trap-nest community varied greatly between months. Wasp-, but not bee density was significantly higher in the dry season compared to the rainy season.

The quality of the 24 agroforestry systems was examined with respect to food availability by measuring the foraging trip durations of three trap-nesting species (a pollinator, a cacao caterpillar-hunting predator, and a spider-hunting intraguild predator). The three species showed strong relations to the availability of food for their larvae, and to light intensity in different ways. The foraging trip duration of all three species did not decrease with increasing forest distance. Only the number of brood cells of the pest-hunting wasp species decreased significantly with increasing forest distance. The foraging trip duration showed only by two of three species (not of the pest-hunting wasp species) a correlation with the number of brood cells. This indicates that the selection of nesting sites is not always related to food availability and also depends on other factors. Therefore, some species may only survive in landscapes including different habitat types that include multiple required resources.

The main results of all experiments examined in this thesis lead to the following conclusions for enhanced 'free' ecological services like pollination, predation, and parasitism and the consequences for the economic value of agroforestry systems:

1. Natural forest and forest fragments should be preserved in the vicinity of coffee agroforestry systems, so that forest-nesting social bees, pest predators, and parasitoids can bridge the distance to the agroforestry systems.

2. Farmers should grow coffee beneath a diversity of shade tree species, but also provide sunlight to promote optimal microclimatic conditions, flowering herbs, and nesting sites for solitary bees and wasps. 


\section{Literaturverzeichnis}

ÅgREN, J. (1996) Population size, pollinator limitation, and seed set in the self-incompatible herb Lythrum salicaria. Ecology 77, 1779-1790.

Aizen, M.A. \& FeInsinger, P. (1994a) Forest fragmentation, pollination, and plant reproduction in a chaco dry forest, Argentina. Ecology 75, 330-351.

Aizen, M.A. \& FeInsinger, P. (1994b) Habitat fragmentation, native insect pollinators, and feral honey bees in Argentine 'chaco Serrano'. Ecological Application 4, 378-392.

Allen-Wardell, G., Bernhardt, P., Bitner, R., Burquez, A., Buchmann, S., Cane, J., Cox, P.A., Dalton, V., Feinsinger, P., Inouye, D., Ingram, M., Jones, C.E., Kennedy, K., Kevan, P., Koopowitz, H., Medellin, R., Medellin-Morales, S., Nabhan, G.P., Pavlik, B., TePedino, V., Torchio, P. \& Walker, S. (1998) The potential consequences of pollinator declines on the conservation of biodiversity and stability of food crop yields. Conservation Biology 12, 8-17.

Altieri, M., Merrick, L. \& Anderson, M.K. (1987) Peasant agriculture and the conservation of crop and wild plant resources. Conservation Biology 1, 49-53.

AmoAh, F.M., Osei-Bonsu, K. \&. Oppong, F.K. (1997) Response of improved robusta coffee to location and management practices in Ghana. Experimental Agriculture 33, 103-111.

BATRA, S.W.T. (1995) Bees and pollination in our changing environment. Apidologie 26, 361-370.

Bawa, K.S., Bullock, S.H., Perry, D.R., Coville, R.E. \& Grayum, M.H. (1985) Reproductive biology of tropical rainforest trees. II. Pollination systems. American Journal of Botany 72, 346-356.

BAwA, K.S. (1990) Plant-pollinator interactions in tropical rain forests. Annual Review of Ecology and Systematics 21, 399-422.

BEER, J. (1987) Advantages, disadvantages and desirable characteristics of shade trees for coffee, cacao and tea. Agroforestry Systems 5, 3-13.

Beer, J., Muschler, R., Kass, D. \& SomarribA, E. (1998) Shade management in coffee and cacao plantations. Agroforestry Systems 38, 139-164.

BORER, E.T. (2002) Intraguild predation in larval parasitoids: implications for coexistence. Journal of Animal Ecology 71, 957-956.

Bosch, J. \& KeMP, W.P. (2002) Developing and establishing bee species as crop pollinators: the example of Osmia spp. (Hymenoptera: Megachilidae) and fruit trees. Bulletin of Entomological Research 92, 3-16.

BunCE, R.G.H. \& HowARD, D.C. (1990) Species dispersal in agricultural habitats. Insitute of Terrestrial Ecology. Natural Environment Research Council. Belhaven Press, London, UK.

BURD, M. (1994) Bateman's principle and plant reproduction: the role of pollen limitation in fruit and seed set. Botanical Review 60, 83-139. 
CAmpBell, D.R. \& Halama, K.J. (1993) Resource and pollen limitations to lifetime seed production in a natural plant population. Ecology 74, 1043-1051.

CANE, J.H. (2001) Habitat fragmentation and native bees: a premature verdict? Conservation Ecology 5, 3 [online] URL: http://www.consecol.org/vol5/iss1/art3.

Carvalho, A. \& Krug, C.A. (1949) Agentes de polização da flor do cafeeiro (Coffea arabica L.). Bragantia 9, 11-24.

COLWELL, R.K. (1997) EstimateS: statistical estimation of species richness and shared species from samples, version 5. User's guide and application published [online]: http://viceroy.eeb.uconn.edu/estimates.

Connor, E.F., Courtney, A.C. \& Yoder, J.M. (2000) Individuals-area relationships: the relationship between animal population density and area. Ecology 81, 734-749.

CONSERVATION InTERnATIONAL (2000) Conservation coffee, CI, Washington, D.C., published at: http:// www.celb.org/pressreleases/conservationcoffeefactsheet5-22.pdf.

Corbet, S.A. (1987) More bees make better crops. New Scientist 115, 40-43.

Corbet, S.A., Williams I.H. \& Osborne, J.L. (1991) Bees and the pollination of crops and wild flowers in the European community. Bee World 72, 47-59.

Corbet, S.A., Fussell, M., Ake, R., Fraser, A., Gunson, C., Savage, A. \& Smith, K. (1993) Temperature and the pollinating activity of social bees. Ecological Entomology 18, 17-30.

Corbet, S.A. (1996) Which bees do plants need? In: MAtheson, A., Buchmann, S.L., O'Toole, C., Westrich, P. \& Williams J.H. (eds): The conservation of bees. Academic press, London, UK, pp. 105-114.

CoRBET, S.A. (1999) Fruit and seed production in relation to pollination and resources in bluebell, Hyacinthoides non-scripta. Oecologia 114, 349-360.

Crane, E. \& Walker, P. (1983) The impact of pest management on bees and pollination. Tropical Development and Research Institute, College House, Wrights Lane, London, UK.

Cunningham, S.A. (2000) Depressed pollination in habitat fragments causes low fruit set. The Proceedings of the Royal Society of London, Series B 267, 1149-1152.

Dale, V.H., Brown, S., Haeuber, R.A., Hobbs, N.T., Huntly, N., Naiman, R.J., Riebsame, W.E., Turner, M.G. \& VAlone, T.J. (2000) Ecological principles and guidelines for managing the use of land. Ecological Applications 10, 639-670.

Davies, K.F., Marguels, C.R. \& Lawrence, J.F. (2000) Which traits of species predict population declines in experimental forest fragments? Ecology 81, 1450-1461.

DeBinski, D.M. \& Holt, R.D. (2000) A survey and overview of habitat fragmentation experiments. Conservation Biology 14, 342-355.

Delaplane, K.S. \& Mayer, D.F. (2000) Crop pollination by bees. CABI Publishing International Wallingford, Oxon, UK. 
Didham, R.K., GHAzoul, J., Stork, N.E. \& Davis, A. (1996) Insects in fragmented forests: a functional approach. Trends of Ecology and Evolution 11, 255-260.

Donaldson, J., NÄNni, I., Zachariades, C. \& KeMPer, J. (2002) Effects of habitat fragmentation on pollinator diversity and plant reproductive success in Renosterveld shrublands of South Africa. Conservation Biology 16, 1267-1276.

Dunning, J.B., Danielson, B.J. \& Pulliam, H.R. (1992) Ecological processes that affect populations in complex landscapes. Oikos 65, 169-175.

EHLERS, B.K. (1999) Variation in fruit set within and among natural populations of the selfincompatible herb Centaurea scabiosa (Asteraceae). Nordic Journal of Botany 19, 653663.

ERIKSSON, O. \& EHRLÉN, J. (1992) Seed and microsite limitation of recruitment in plant populations. Oecologia 91, 360-364.

Escalante, E. (1995) Coffee and agroforestry in Venezuela. Agroforestry Today 7, 5-7.

Fagan, W.F., Meir, E., Prendergast, J., Folarin, A. \& Kareiva, P. (2001) Characterizing population vulnerability for 158 species. Ecology Letters 4, 132-138.

Feber, R.E., Smith, H. \& Macdonald, D.W. (1996) The effects on butterfly abundance of the management of uncropped edges of arable fields. Journal of Applied Ecology 33, 1191-1205.

FERWERDA, F.P. (1984) Coffee breeding in Java. Economic Botany 2, 258-272.

Fox, J., Truong, D., Rambo, T., Tuyen, N., CuC, L. \& Leisz, S. (2000) Shifting cultivation: a new old paradigm for managing tropical forests. BioScience 50, 521-528.

FrEE, J.B. (1993) Insect pollination of crops. Academic Press, London, UK.

FREITAS, B.M. \& PAXTON, R.J. (1998) A comparison of two pollinators: the introduced honey bee Apis mellifera and an indigenous bee Centris tarsata on cashew Anacardium occidentale in its native range of NE Brazil. Journal of Applied Ecology 35, 109-121.

Fujisaka, S., Escobar, G. \& VeneKlaAs, E.(1998) Plant community diversity relative to human land uses in an Amazon forest colony: Biodiversity and Conservation 7, 41-57.

GASTON, K.J. (1994) Rarity. Chapman and Hall, London, UK.

GathmanN, A. (1998) Bienen, Wespen und ihre Gegenspieler in der Agrarlandschaft: Artenreichtum und Interaktionen in Nisthilfen, Aktionsradien und Habitatbewertung. Dissertation an den Mathematisch-Naturwissenschaftlichen Fakultäten der GeorgAugust-Universität zu Göttingen. Cuvillier Verlag Göttingen.

Gathmann, A., Greiler, H.J. \& TscharntKe, T. (1994) Trap-nesting bees and wasps colonizing set-aside fields: succession and body size, management by cutting and sowing. Oecologia 98, 8-14.

Gathmann, A. \& TscharntKe, T. (1999) Naturschutz-Bewertung mit Bienen und Wespen in Nisthilfen. Artenspektrum, Interaktionen und Bestimmungsschlüssel. Naturschutz und Landschaftspflege Baden-Württemberg 73, 277-305. 
GATHMAnN, A. \& TscharntKe, T. (2002) Foraging ranges of solitary bees. Journal of Animal Ecology 71, 757-764.

Ghazoul, J., Liston, K.A. \& Boyle, T.J.B. (1998) Disturbance-induced density-dependent seed set in Shorea siamensis (Dipterocarpaceae), a tropical forest tree. Journal of Ecology 86, 462-473.

Goodell, K. (2003) Food availability affects Osmia pumila (Hymenoptera: Megachilidae) foraging, reproduction, and brood parasitism. Oecologia 134, 518-527.

Greenberg, R., Bichier, P., Cruz Angon, A., MacVean, C., Perez, R. \& Cano, E. (2000) The impact of avian insectivory on arthropods and leaf damage in some Guatemalan coffee plantations. Ecology 81, 1750-1755.

GreENWOOD, S.R. (1987) The role of insects in tropical forest food webs. AMBIO 16, 267-271.

HAMBÄCK, P.A. (2001) Direct and indirect effects of herbivory: Feeding by spittlebugs affects pollinator visitation rates and seedset of Rudbeckia hirta. Ecoscience 8, 45-50.

HARRIS, A.C. (1994) Ancistrocerus gazella (Hymenoptera: Vespoidea: Eumenidae): a potentially useful biological control agent for leafrollers Planotortrix octo, $P$. excessana, Ctenopseustis oblinquana, $C$. herana and Epiphyas postvittana (Lepidoptera: Tortricidae) in New Zealand. New Zealand Journal of Crop and Horticultural Science 22, 235-238.

HARRISON, S. \& BRUNA, E. (1999) Habitat fragmentation and large-scale conservation: what do we know for sure? Ecography 22, 225-232.

HEARD, T.A. (1994) Behavior and pollinator efficiency of stingless bees and honey-bees on macadamia flowers. Journal of Applied Research 33, 191-198.

HERRERA, C.M. (2000) Measuring the effects of pollinators and herbivores: evidence for nonadditivity in a perennial herb. Ecology 81, 2170-2176.

Herzog, F. (1994) Multipurpose shade trees in coffee and cacao plantations in Côte d'Ivore. Agroforestry System 27, 259-267.

Holt, R.D. \& Polis, G.A. (1997) A theoretical framework for intraguild predation. American Naturalist 149, 745-764.

Holt, R.D., Lawton, J.H., Polis, G.A. \& Martinez, N.D. (1999) Trophic rank and speciesarea relationship. Ecology 80, 1495-1504.

Horner-Devine, M.C., Daily, G.C., Ehrlich, P.R. \& BoggS, C.L. (2003) Countryside biogeography of tropical butterflies. Conservation Biology 17, 168-177.

Huston, M.A. (1999) Local processes and regional patterns: appropriate scales for understanding variation in the diversity of plants and animals. Oikos 86, 393-401.

IRWIN, R.E., Brody, A. \& WASER, N.M. (2001) The impact of floral larceny on individuals, populations, and communities. Oecologia 129, 161-168.

JAYAsingh, D.B. \& FreEmAn, B.E. (1980) The comparative population dynamics of eight solitary bees and wasps (Aculeata; Apocrita; Hymenoptera) trap-nested in Jamaica. Biotropica 12, 214-219. 
KAREIVA, P. (1987) Habitat fragmentation and the stability of predator-prey interactions. Nature 326, 388-390.

Kearns, C.A., InOUYe, D.W. \& WASER, N.M. (1998) Endangered mutualisms: the conservation of plant-pollinator interactions. Annual Review of Ecology and Systematics 29, 83-112.

Kevan, P.G. \& Phillips, T.P. (2001) The economic impacts of pollinator declines: an approach to assessing the consequences. Conservervation Ecology 5, 1-19.

Klein, A.M., Steffan-Dewenter, I., Buchori, D. \& Tscharntke, T. (2002a) Effects of land-use intensity in tropical agroforestry systems on flower-visiting and trap-nesting bees and wasps. Conservation Biology 16, 1003-1014.

Klein, A.M., Steffan-Dewenter, I. \& TscharntKe, T. (2002b) Predator-prey ratios on cocoa along a land-use gradient in Indonesia. Biodiversity and Conservation 11, 683693.

Klein, A.M., Steffan-Dewenter, I. \& TscharntKe, T. (2003) Bee pollination and fruit set of Coffea arabica and C. canephora (Rubiaceae). American Journal of Botany 90, 153 157.

Klein, A.M., Steffan-Dewenter, I. \& TscharntKe, T. (in press a) Fruit set of highland coffee increases with the diversity of pollinating bees. The Proceedings of the Royal Society London, Series B.

Klein, A.M., Steffan-Dewenter, I. \& TscharntKe, T. (in press b) Flower visitation and fruit set of Coffea canephora in relation to local and regional agroforestry management. Journal of Applied Ecology.

Knaus, K. (1997) Reise Know-How; Sulawsi, Indonesien mit Anreise durch Java und Bali. Reise Know-How-Verlag Peter Rump GmbH, Bielefeld, Germany.

Kremen, C., WiLliams, N.M. \& ThORP, R.W. (2003) Crop pollination from native bees at risk from agricultural intensification. Proceeding of the National Academy of Sciences, in press. [Online]: http://www.pnas.org/cgi/doi/10.1073/pnas.262413599

Krombein, K.V. (1967) Trap-nesting wasps and bees: life-histories, nests and associates. Smithsonian Press, Washington, D.C., USA.

Kruess, A. \& TscharntKe, T. (1994) Habitat fragmentation, species loss, and biological control. Science 264, 1581-1584.

KRug, C.A. \& CostA, A.S. (1947) Crição de variedades melhoradas de café. Fazenda 42, 4647.

KUNIN, W.E. (1993) Sex and the single mustard: population density and pollinator behaviour effects on seed-set. Ecology 74, 2145-2160.

KUNIN, W.E. (1997) Population size and density effects in pollination: pollinator foraging and plant reproductive success in experimental arrays of Brassica Kaber. Journal of Ecology 85, 225-234. 
LARSON, B.M.H., BARRETT, L. \& BARRETT, S.C.H. (1999) The pollination ecology of buzzpollinated Rhexia virginica (Melastomataceae). American Journal of Botany 86, 502511.

LARSON, B.M.H., BARRETT, L. \& BARRETT, S.C.H. (2000) A comparative analysis of pollen limitation in flowering plants. Biological Journal of the Linnean Society 69, 503-520.

LASALle, J. \& Gould, J.D. (1993) Hymenoptera: their diversity, and their impact on the diversity of other organisms. In: Hymenoptera and biodiversity. CAB International Wallingford: 1-26.

LAURANCE, W.F. \& BIERREGAARD, R.O. JR. (1997) Tropical forest remnants. The University of Chicago Press, Chicago, USA.

LAURANCE, W.F. (2000) Cut and run: the dramatic rise of transnational logging in the tropics. Trends in Ecology and Evolution 15, 433-434.

LENNE, J. \& WoOD, D. (1999) Optimizing biodiversity for productive agriculture. In: WooD, D. \& LENNE, J. (eds.): Agrobiodiversity: Characterization, Utilization and Management. CABI Publishing, Wallingford, UK, pp. 447-470.

Le Pelley, R.H. (1973) Coffee insects. Annual Review of Entomology 18, 121-142.

Liow, L.H., SodHI, N.S. \& ELMQVIST, T. (2001) Bee diversity along a disturbance gradient in tropical lowland forests of South-East Asia. Journal of Applied Ecology 38, 180-192.

MaCVEan, C. (1997) Coffee growing: Sun or shade? Science 275, 1552.

MALOOF, J.E. \& INOUYE, D.W. (2000) Are nectar robbers cheaters or mutualists? Ecology 81, 2651-2661.

MANRIQUe, A.J. \& ThimAnN, R.E. (2002) Coffee (Coffea arabica) pollination with africanized honeybees in Venezuela. Interciencia 27, 414-416.

MANUGistics (1997) Statgraphics plus for Windows 3.0. Manugistics, Inc., Rockville, Maryland, USA.

MARINO, P.C. \& LANDIS, D.A. (1996): Effect of landscape structure on parasitoid diversity in agroecosystems. Ecological Applications 6, 276-284.

MATHESON, A. (1994) Forage for bees in an agricultural landscape. International Bee Research Association, Cardiff, UK.

McDAdE, L.A. \& Kinsman, S. (1980) The impact of floral parasitism in two neotropical hummingbird-pollinated plant species. Evolution 34, 944-958.

McDonald, J.H. (1930) Coffee growing: with special reference to East Africa. East Africa Ltd., London, UK.

MC GREGOR, S.E. (1976) Insect pollination of cultivated crop plants. US Department of Agriculture.

Menalled, F.D., Marino, P.C., Gage, S.H. \& LANDis, D.A. (1999) Does agricultural landscape structure affect parasitism and parasitoid diversity? Ecological Applications 9, 634-641. 
MiCHENER, C.D. (1979) Biogeography of the bees. Annals of the Missouri botanical garden 66, 278-347.

Moguel, P. \& Toledo, V.M. (1999) Biodiversity conservation in traditional coffee systems of Mexico. Conservation Biology 13, 11-21.

Mori, S.A. \& Prance, G.T. (1987) Phenology. Memoirs of The New York Botanical Garden 44, 124-136, available at: www.nybg.org/bsci/french_guiana/phenology.html.

Muschler, R.G. \& Bonnemann, A. (1997) Potentials and limitations of agroforestry for changing land-use in the tropics: experiences from Central America. Forest Ecology and Management 91, 61-73.

Naeem, S., Thompson, L.J., Lawler, S.P., Lawton, J.H. \& Woodfin, R.M. (1994) Declining biodiversity can alter the performance of ecosystems. Nature 368, 734-737.

NAIR, P.K.R. (1993) An introduction to agroforestry. Kluwer Academic Publishers, Dordrecht.

NAIR, P.K.R. (1998) Directions in tropical agroforestry research: past, present, and future. Agroforestry Systems 38, 223-245.

Nogueira-Neto, P., Carvalho, A. \& Antunes, H. (1959) Efeito da exclusão dos insetos polinizadores na produção do café Bourbon. Bragantia 18, 441-468.

OKU, S. \& NishidA, T. (1999) Factors affecting female-biased sex ratio in a trap-nesting wasp, Trypoxylon malaisei. Researches on Population Ecology 41, 169-175.

OKUYAMA, T. (2002) The role of antipredator behavior in an experimental community of jumping spiders with intraguild predation. Population Ecology 44, 121-125.

O’Toole, C. \& Raw, A. (1991) Bees of the world. Facts on File, New York; New York, USA.

PARKER, I.M. \& HAUBENSAK, K.A. (2002) Comparative pollinator limitation of two nonnative shrubs: do mutualisms influence invasions? Oecologia 130, 250-258.

PATt, J.M., HAMiLton, G.C. \& LAShOMB, J.H. (1997) Foraging success of parasitoid wasps on flowers: Interplay of insect morphology, floral architecture and searching behavior. Entomologia Experimentalis et Applicata 83, 21-30.

Peeters, L.Y.K., Soto-Pinto, L., Perales, H., Montoya, G. \& Ishiki, M. (2003) Coffee production, timber, and firewood in traditional and Inga-shaded plantation in Southern Mexico. Agriculture, Ecosystems \& Environment 95, 481-493.

Perfecto, I., Rice, R.A., Greenberg, R. \& VAn Der Voort, M.E. (1996) Shade coffee: a disappearing refuge for biodiversity. Shade coffee plantations can contain as much biodiversity as forest habitats. BioScience 46, 598-608.

Perfecto, I. \& SNelling, R. (1995) Biodiversity and the transformation of a tropical agroecosystem: ants in coffee plantation. Ecological Applications 5, 1084-1097.

Perfecto, I. \& VAndermeer, J. (1996) Microclimatic changes and the indirect loss of ant diversity in a tropical agroecosystem. Oecologia 108, 577-582. 
Perfecto, I., Vandermeer, J., Hanson, P. \& Cartin, V. (1997) Arthropod biodiversity loss and the transformation of a tropical agroecosystem. Biodiversity and Conservation $\mathbf{6}$, 935-945.

Perfecto, I. \& VANDERMEer, J. (2002) Quality of agroecological matrix in a tropical montane landscape: ants in coffee plantations in Southern Mexico. Conservation Biology 16, 174-182.

Pimentel, D., Stachow, U., Takacs, D.A., Brubaker, H.W., Dumas, A.R., Meaney, J.J., O’NEIL, J.A.S., ONSI, D.E. \& CoRZILIUS, D.B. (1992) Conserving biological diversity in agricultural/forestry systems. Most biological diversity exists in human-managed ecosystems. BioScience 42, 454-362.

PotTs, S.G. \&WILLMER, P. (1997) Abiotic and biotic factors influencing nest-site selection by Halictus rubicundus, a ground-nesting halictine bee. Ecological Entomology 22, 319328.

Power, A.G. \& FLECKER, A.S. (1996) The role of biodiversity in tropical managed ecosystems. In: Orians, G.L.H., Dirzo, R. \& Cushman, J.H. (eds.): Biodiversity and ecosystem processes in tropical forests. Ecological studies 122, Springer Verlag, Berlin, Germany, pp. 173-194.

Purseglove, J.W. (1968) Tropical crops. Dicotyledons. London, UK (2 volumes).

RAPpole, J.H., King, D.I. \& RiverA, J.H.V. (2003) Coffee and conservation. Conservation Biology 17, 334-336.

RATHCKE, B.J. \& JULES, E.S. (1993) Habitat fragmentation and plant-pollinator interactions. Current Science 65, 273-277.

RATHCKe, B.J. \& JULES, E.S. (1999) Mechanisms of reduced Trillium recruitment along edges of old-growth forest fragments. Conservation Biology 13, 784-793.

RAW, A. \& FreE, J.B. (1977) The pollination of coffee (Coffea arabica) by honeybees. Tropical Agriculture 54, 365-371.

ReHM, S. \& Espig, G. (1991) The cultivated plants of the tropics and subtropics. Cultivation, economic value, utilization. Weikersheim, Markgraf, Germany.

Reddy, A.G.S., Raju, K.V.V.S.N. \& Dharmaraj, P.S (1988) Pollination in cultivars of Coffea arabica L. Journal of Coffee Research 18, 78-84.

Reichhardt, L., Mellink, E., Nahan, G.P. \& Rea, A. (1994) Habitat heterogenity and biodiversity associated with indigenous agriculture in the Sonoran Desert. Etnoecológica 3, 21-36.

RENNER, S.S. (1998) Effects of habitat fragmentation on plant pollinator interactions in the tropics. In:. NewBery, D.M., PRINS, H.H.T. \& Brown, N. (eds.): Dynamics of tropical communities. Blackwell Science, Oxford, UK, pp. 339-360.

Rice, R. \& GReEnBerG, R. (2000) Cacao cultivation and the conservation of biological diversity. Ambio 29, 167-173. 
RICE, R.A. \& WARD, J.R. (1997) Coffee, conservation, and commerce in the Western Hemisphere. Smithsonian Migratory Bird Center and Natural Resources Defense Council, Washington, D.D.

RICHARDS, A.J. (2001) Does low biodiversity resulting from modern agricultural practice affect crop pollination and yield? Annals of Botany 88, 165-172.

RICKETTS, T.H. (2001) The matrix matters: effective isolation in fragmented landscapes. The American Naturalist 158, 87-99.

Ricketts, T.H., DAILY, G.C., Ehrlich, D.P.R. \& FAY, J.P. (2001) Countryside biogeography of moths in a fragmented landscape: Biodiversity in native and agricultural habitats. Conservation Biology 15, 378-388.

RiNALDI, I.M.P. \& SANCHES RuIZ, G.R. (2002) Spider communities (Araneae) on rubber tree (Hevea brasiliensis Muell. Arg.) plantations in Sao Paulo State, Brazil. Revista Brasileira de Zoologia 19, 781-788.

Risch, S.J., ANDOW, D. \& Altieri, M.A. (1983) Agroecosystem diversity and pest control: data, tentative conclusions, and new directions. Environmental Entomolology 12, 625629.

Roland, J. (2000) Landscape ecology of parasitism. In: HochBerg, M.E. \& IVES, A.R. (eds.): Parasitoid population biology. Princeton University Press, Princeton, pp. 83100.

ROLAND, J. \& TAYLOR, P.D. (1995) Herbivore-natural enemy interactions in fragmented and continous forests. In: CAPPUCINO, N. \& PRICE, P.W. (eds.): Population dynamics: New Approaches and Synthesis. Academic Press, San Diego, pp. 195-208.

RolAND, J. \& TAYLOR, P.D. (1997) Insect parasitoid species respond to forest structure at different spatial scales. Nature 386, 710-713.

RosenheIM, J.A. (1990) Density-dependent parasitism and the evolution of aggregated nesting in the solitary Hymenoptera. Annals of the Entomological Society of America 83, 277-286.

RouBIK, D.W. (1989) Ecology and natural history of tropical bees. Cambridge University Press, USA.

RouBIK, D.W. (1993) Tropical pollinators in the canopy and understorey: field data and theory for stratum 'preferences'. Journal of Insect Behaviour 6, 659-673.

RoubIK, D.W. (1995) Pollination of cultivated plants in the tropics, FAO Agricultural Services Bulletin 118.

RoubiK, D.W. (2002a) The value of bees to the coffee harvest. Nature 417, 708.

RoubIK, D.W. (2002b) Feral African bees augment neotropical coffee yield. In: KEVAN, P.G. \& IMPERATRIZ-FONSECA, V. (eds): International workshop on the conservation and sustainable use of pollinators International Bee Research Association, Cardiff, UK, pp. 255-265.

Sala, O.E., Chapin III, F.S., Armesto, J.J., Berlow, E., Bloomfield, J., Dirzo, R., Huber-Sanwald, E., HuenneKe, L.F., Jackson, R.B., Kinzig, A., Leemans, R., 
Lodge, D.M., Mooney, H.A., Oesterheld, M., Poff, N.L., Sykes, M., Walker, B.H., WALKER, M. \& WALL, D.H. (2000) Global biodiversity scenarios for the year 2100. Science 287, 1770-1774.

Schelhas, J. \& GREENBERG, R. (1996) Forest patches in tropical landscapes. Island Press, Washington, D.C.

Schoener, T.W. \& SPILler, D.A. (1992) Is extinction rate related to temporal variability in population size? An empirical answer for orb spiders. American Naturalist 139, 11761207.

SIEBERT, S.F. (2002) From shade- to sun-grown perennial crops in Sulawesi, Indonesia: implications for biodiversity conservation and soil fertility. Biodiversity and Conservation 11, 1889-1902.

Siemann, E., HAARstad, J. \& Tilman, D. (1999) Dynamics of plant and arthropod diversity during old field succession. Ecography 22, 406-414.

Smith, N.J.H., Williams, T.J., Plucknett, D.L. \& Talbot, J.P. (1992) Tropical forests and their crops. Cornell University Press, Ithaca, New York, USA.

SoKAL, R.R. \& ROHLF, F.J. (1995) Biometry, the principles and practice of statistics in biological research. Freeman, New York, USA.

Soto-Pinto, L., Perfecto, I., Castillo-Hernandez, J., \& Caballero-Nieto, J. (2000) Shade effect on coffee production at the northern Tzeltal zone of the state of Chiapas, Mexico. Agriculture, Ecosystystems and Environement 80, 61-69.

StefFAn-Dewenter, I. \& TSCHARNTKe, T. (1999) Effects of habitat isolation on pollinator communities and seed set. Oecologia 121, 432-440.

SteFfan-Dewenter, I. \& TSChARNTKE, T. (2000) Resource overlap and possible competition between honey bees and wild bees in central Europe. Oecologia 122, 288296.

StefFan-Dewenter, I. \& TscharntKe, T. (2001) Succession of bee communities on fallows. Ecography 24, 83-93.

StEFFAN-DEWENTER, I. (2002) Landscape context affects trap-nesting bees, wasps, and their natural enemies. Ecological Entomology 27, 631-637.

STEFFAn-Dewenter, I. (in press) The importance of habitat area and landscape context for species richness of bees and wasps in fragmented orchard meadows. Conservation Biology.

Steffan-Dewenter, I., Münzenberg, U., Bürger, C., Thies \& C., TscharntKe, T. (2002) Scale-dependent effects of landscape structure on three pollinator guilds. Ecology 83, 1421-1432.

StefFan-Dewenter, I. \& KuHn, A. (2003) Honeybee foraging in differentially structured landscapes. Proccedings of the Royal Society London, Series B: $\mathrm{http}: / /$ ninetta.ingentaselect.com/vl=9265332/cl=47/nw=1/fm=docpdf $/ \mathrm{rpsv} /$ catchword $/ \mathrm{r}$ sl/09628452/v270n1515/s3/p569.

Stone, G.N. (1994) Activity patterns of females of the solitary bee Anthophora plumipes in 
relation to temperature, nectar supplies and body size. Ecological Entomology 19, 177189.

Stone, G.N., Gilbert, F., Willmer, P., Potts, S., Semida, F. \& Zalat, S. (1999) Windows of opportunity and the temporal structuring of foraging activity in a desert solitary bee. Ecolological Entomology 24, 208-221.

Strohm, E., Daniels, H., Warmers, C. \& Stoll, C. (2002) Nest provisioning and a possible cost of reproduction in the megachilid bee Osmia rufa studied by a new observation method. Ethology Ecology \& Evolution 14, 255-268.

Strohm, E. \& MARLIANI, A. (2002) The cost of parental care: prey hunting in a digger wasp. Behavioural Ecology 13, 52-58.

SutHERLAND, W.J. (1996) From individual behaviour to population ecology. Oxford University Press, UK.

TASChDJian, E. (1932) Beobachtung über Variabilität, Dominanz und Vizinismus bei Coffea arabica. Zeitschrift für Züchtung, Reihe A, Pflanzenzüchtung 17, 341-354.

Tewksbury, J.J., Levey, D.J., Haddad, N.M., Sargent, S., Orrock, J.L, Weldon, A., DAnielson, B.J., BRINKERHOFF, J., DAMSChEN, E.I. \& TOWNSEND, P. (2002) Corridors affect plants, animals, and their interactions in fragmented landscapes. The Proceedings of the National Academy of Sciences of the United States of America 99, 12923-12936.

Thies, C. \& TscharntKe, T. (1999) Landscape structure and biological control in agroecosystems. Science 285, 893-895.

Thomas, J.A., Bourn, N.A.D., Clarke, R.T., Steward, K.E., Simcox, D.J., Pearman, G.S., CURTIS, R. \& GoOdGER, B. (2001) The quality and isolation of habitat patches both determine where butterflies persist in fragmented landscapes. The Proceedings of the Royal Society of London, Series B 268, 1791-1796.

Tilman, D., Fargione, J., Wolff, B., D’Antonio, C., Dobson, A., Howarth, R., Schindler, D., Schlesinger, W.H., Simberloff, D. \& Swackhamer, D. (2001) Forecasting agriculturally driven global environmental change. Science 292, 281-284.

Toledo, V.M., ORTIZ, B. \& Medellin, S. (1994) Biodiversity islands in a sea of pastureland: indigenous resource management in the humid tropics of Mexico. Etnoecológica 3, 37 50 .

TscharntKe, T., Gathmann, A. \& StefFan-Dewenter., I. (1998) Bioindication using trapnesting bees and wasps and their natural enemies: community structure and interactions. Journal of Applied Ecology 35, 708-719.

TSCHARNTKE, T. \& KRUESS, A. (1999) Habitat fragmentation and biological control. In: HAWKins, B.A. \& CORNELl, H.V. (eds.): Theoretical approaches to biological control. Cambridge, UK, pp. 235-253.

TscharntKe, T. (2000) Parasitoid populations in the agricultural landscape. In: HochBerG, M.E. \& IVES, A.R. (eds.): Theoretical approaches to biological control. Cambridge, UK, pp. 190-205. 
Tscharntke, T., Steffan-Dewenter, I., Kruess, A. \& Thies, C. (2002a) Contribution of small habitat fragments to conservation of insect communities of grassland-cropland landscape mosaics. Ecological Application 12, 354-363.

TscharntKe, T., Steffan-Dewenter, I., Kruess, A. \& Thies, C. (2002b) Characteristics of insect populations on habitat fragments - a mini review. Ecological Research 17, 229239.

Turnbull, L.A., Crawley, M.J. \& Rees, M. (2000) Are plant populations seed-limited? A review of seed sowing experiments. Oikos 88, 225-238.

TwOREK, S. (2002) Different bird strategies and their responses to habitat changes in an agricultural landscape. Ecological Research 17, 339-359.

Vandermeer, J., VAnnoordwijk, M., Anderson, J., Ong, C. \& Perfecto, I. (1998) Global change and multi-species agroecosystems: Concepts and issues. Agriculture Ecosystems and Environment 67, 1-22.

VAN EMDEN, H.F. (1990) Plant diversity and natural enemy efficiency in agroecosystems. In: Mackauer, M., Ehler, L. \& Roland, J. (eds.): Critical issues in biocontrol. Interecept Ltd., Andover, UK, pp. 63-77.

Van Hall, C.J.J. (1938) Coffee selection in the Netherlands Indies. Bulletin of the Colonial Institute of Amsterdam 2, 135-145.

VAN NouHuYs, S. \& HANSKI, I. (2002) Colonization rates and distances of a host butterfly and two specific parasitoids in a fragmented landscape. Journal of Animal Ecology 71, 639-650.

VANNiEUwstadT, M.G.L. \& IRAHETA, C.E.R. (1996) Relation between size and foraging range in stingless bees (Apidae, Meliponinae). Apidologie 27, 219-228.

Vinson, S.B., Frankie, G.W. \& Barthell, J. (1993) Threats to the diversity of solitary bees in a neotropical dry forest in Central America. In: LASALLE, J. \& Gould, I.D. (eds.): Hymenoptera and Biodiversity. Wallingford, CAB International, UK., pp. 53-82.

VitouseK, P.M., Mooney, H.A., Lubchenco. J. \& Melillo, J.M. (1997) Human domination of Earth's ecosystems. Science 277, 494-499.

Waddington, K.D., Visscher, P.D., Herbert, T.J. \& Richter, M.R. (1994) Comparison of forager distribution from matched honeybee colonies in suburban environments. Behavioural Ecology and Sociobiology 35, 423-429.

Warren, M.S., Hill, J.K., Thomas, J.A., Asherm J., Fox, R., Huntley, B., Roy, D.B., Telfer, M.G., JeffCoate, S., Harding, P., JeffcoAte, G., Willis, S.G., GreatoreXDavies, J.N., Moos, D. \& Thomas, C.D. (2001) Rapid responses of British butterflies to opposing forces of climate and habitat change. Nature 414, 65-69.

Watt, A.D., Stork, N.E., Eggleton, P., Srivastara, D., Bolton, B., Laren, T.B., BRENDELL, M.J.D. \& BignelL, D.E. (1997) Impact of forest loss and regeneration on insect abundance and diversity. In: WATT, S.D., STORK, N.E. \& HunTER, M.D. (eds.): Forest and insects. Champam \& Hall, London, UK, pp. 273-286.

Westrich, P. (1989) Die Wildbienen Baden-Württenbergs (2 Bde.), Ulmer Stuttgart, Germany. 
WESTRICH, P. (1996) Habitat requirements of central European bees and problems of partial habitats. In: Matheson, A., Buchmann, S.L., O'Toole, C., Westrich, P. \& Williams, I.H. (eds.): The conservation of bees. Academic Press, London, UK, pp. 116.

WiLBY, A. \& ThOMAS, M.B. (2002) Natural enemy diversity and pest control: patterns of pest emergence with agricultural intensification. Ecological Letters 5, 353-360.

Willmer, P.G. \& Stone, G.N. (1989) Incidence of entomophilous pollination of lowland coffee (Coffea canephora); the role of leaf cutter bees in Papua New Guinea. Entomologia Experimentalis et Applicata 50, 113-124.

Zimmerman, M. \& PYKe, H. (1988) Reproduction in Polemonium: assessing the factors limiting seed set. American Naturalist 131, 723-738. 


\section{Publikationen der Autorin}

\section{Zeitschriften}

Klein, A.M., Steffan-Dewenter, I. \& Tscharntke, T. (2002): Predator-prey ratios on cocoa in a land-use gradient in Indonesia. Biodiversity and Conservation 11, 683-693.

KLein, A.M., Steffan-Dewenter, I., Buchori, D. \& Tscharntke, T. (2002): Effects of land-use intensity in tropical agroforestry systems on flower-visiting and trap-nesting bees and wasps. Conservation Biology 11, 683-693.

KLEIN, A.M. (2002) Viele Bienenarten erzeugen viel Kaffee. Deutsches Bienenjournal 10, 24-25.

Tscharntke, T., Bürger, C., Eber, S., Gabriel, D., Grabe, H., Grönmeier, M., Holzschuh, A., Jahn, S., Klein, A.M., Klipfel, S., Kluth, S., Krauss, J., Kruess, A., Lehmann, K., Poveda, K., Roschewitz, I., Schiele, S., Schmidt, M., Schulze, C., Steffan-Dewenter, I., Sundmacher, F., Thies, C., Veddeler, D. \& Westphal, C. (2002): Wenn der Räuber seinen Feind verliert. Thema: Leben braucht Vielfalt Biodiversität. Georgia Augusta 1, 41-46.

KLein, A.M., Steffan-Dewenter, I. \& Tscharntke, T. (2003) Bee pollination and fruit set of Coffea arabica and C. canephora (Rubiaceae). American Journal of Botany 90, 153157.

KLein, A.M., Steffan-Dewenter, I. \& TscharntKe, T. (2003): Fruit set of highland coffee increases with the diversity of pollinating bees. The Proceedings of the Royal Society of London, Series B 270, 955-961.

Tscharntke, T., Klein, A.M., Kruess, A., Steffan-Dewenter, I. \& Thies, C. (in press): Biodiversität und Pflanze-Insekt-Interaktionen in Kulturlandschaften. Perspektiven der Biodiverstiätsforschung, Wilmann \& Gradstein (eds.), Senckenberg.

\section{Eingereicht oder in Vorbereitung}

KLein, A.M., Steffan-Dewenter, I. \& Tscharntke, T. (submitted): Pollinator diversity and fruit set of $C$. canephora depend on habitat isolation and shading of agroforestry systems. Journal of Applied Ecology.

Krauss, J., Klein, A.M., Steffan-Dewenter, I. \& TscharntKe, T. (submitted): Effects of habitat area, isolation, and landscape diversity on plant species richness of calcareous grasslands. Biodiversity and Conservation.

Klein, A.M., Steffan-Dewenter, I. \& Tscharntke, T. (submitted): Effects of forest distance on trophic interactions and diversity of trap-nesting bees, wasps, and their natural enemies in tropical agroforestry systems. Oecologia.

KLein, A.M., Steffan-Dewenter, I. \& TscharntKe, T. (submitted): Foraging trip duration and reproductive success of megachilid bees, eumenid wasps, and pompilid wasps in tropical agroforestry systems Journal of Animal Ecology.

Klein, A.M., Steffan-Dewenter, I. \& Tscharntke, T. (in preparation): Bee diversity in agroforestry systems. Biotropica. 


\section{Tagungsbeiträge, Vorträge}

KLein, A.M., Steffan-Dewenter, I. \& TscharntKe, T. (2000): Blütenbesucher am Kaffee und Arthropoden am Kakao in einem Landnutzungsgradienten in Sulawesi. Verhandlungen der Gesellschaft für Ökologie, Band 30: 100.

KLein, A.M., Steffan-Dewenter, I. \& TscharntKe, T. (2000): Einfluss der Landnutzungsintensität auf Blütenbesucher am Kaffee und Arthropoden am Kakao in Agroforstsystemen in Zentral-Sulawesi. Deutscher Tropentag 2000, pp.62.

KLein, A.M., Steffan-Dewenter, I. \& TscharntKe, T. (2002): Bestäuberlimitierung an Coffea canephora und Coffea arabica in tropischen Agroforstsystemen. 15. Jahrestagung der Gesellschaft für Tropenökologie, p. 49.

\section{Tagungsbeiträge, Poster}

Klein, A.M., Steffan-Dewenter, I. \& TscharntKe, T. (2002): Trap-nesting bees and wasps in tropical agroforestry systems of different land-use intensity. 15. Jahrestagung der Gesellschaft für Tropenökologie, p. 129.

KLein, A.M., Steffan-Dewenter, I., Buchori, D. \& Tscharntke, T. (2002): Trap-nesting bees, wasps, and their natural enemies in tropical agroforestry systems and natural forest. Verhandlungen der Gesellschaft für Ökologie, Band 32: 78.

Klein, A.M., Steffan-Dewenter, I. \& Tscharntke, T. (2001): Pollination and fruit set of coffee in Indonesian agroforestry systems. Verhandlungen der Gesellschaft für Ökologie, Band 31: 314.

Klein, A.M., Steffan-Dewenter, I. \& TscharntKe, T. (2002): Pollen limitation of the self-fertile highland coffee C.arabica. Verhandlungen der Gesellschaft für Ökologie, Band 32: 256.

Klein, A.M., Schulze, C.H., Steffan-Dewenter, I. \& Tscharntke, T. (2002): Bee diversity and the pollination of coffee in Central Sulawesi. International Symposium in Bogor (Indonesia). Land use, nature conservation, and stability of rainforest margins in Southeast Asia.

Klein, A.M., Buchori, D., Steffan-Dewenter, I. \& Tscharntke, T. (2002): Effects of land use on trap-nesting bees and wasps in and around the Lore-Lindu National Park. International Symposium in Bogor (Indonesia). Land use, nature conservation, and stability of rainforest margins in Southeast Asia.

Klein, A.M., Steffan-Dewenter, I. \& Tscharntke, T. (2002): Species richness and foraging behaviour of trap-nesting bees and wasps in tropical agroforestry systems. 16 . Jahrestagung der Gesellschaft für Tropenökologie, p. 132. 


\section{Danksagung}

Herrn Prof. Dr. Teja Tscharntke danke ich für die äußerst interessante und vielseitige Themenstellung, die gute und nette Betreuung, die zahlreichen konstruktiven Diskussionen und die kurze aber gute Hilfe im Gelände. P.D. Dr. Ingolf Steffan-Dewenter danke ich für seine stetige Diskussionsbereitschaft und wertvolle Anregungen in allen Stadien der gesamten Promotionszeit. Prof. Dr. Matthias Schäfer vom Institut für Zoologie und Anthropologie danke ich für die bereitwillige Übernahme des Korreferats.

Herzlich gedankt sei auch den Mitgliedern und dem gesamten Koordinationsteam des SFB 552 ,Stability of Tropical Forest Margins'. Vielen Dank auch an die sehr hilfsbereiten Fahrer der Geländewagen.

Der Graduiertenförderung der Universität Göttingen, dem Deutschen Akademischen Austauschdienst sowie der Deutschen Forschungsgemeinschaft danke ich für die finanzielle Unterstützung des Projektes.

Sehr herzlich möchte ich zwei indonesischen Forststudenten der Universität in Palu, Salma Andi Kaisang und Sudirman D.G. Massiri, danken. Beide haben mit viel Engagement bei den Beobachtungen der Sammelflugzeiten der nisthilfenbewohnenden Bienen und Wespen geholfen und regelmäßig die Nisthilfen kontrolliert und einen Grossteil der Nester ausgewertet. Ohne ihre Hilfe hätte nie ein so großer Datensatz entstehen können! Bei zahlreichen Indonesischen Kleinbauern möchte ich mich für die Bereiterklärung, ihre KaffeeAnbausysteme zu untersuchen, bedanken. Ecil Tamalagi und zahlreichen Freunden danke ich für die Unterstützung bei der Geländearbeit. Der Familie Kabih aus Posso danke ich für die Bereitstellung von Wohn- und Arbeitsraum, Ibu Effi für die gute deutsch-indonesische Küche. Der WG in Jalan Nuri (Gesa, Kerstin, Miet, Robert) danke ich für nette, tropische Abende.

Für die Determination der Bienen und Wespen danke ich Dr. J. Gusenleitner (Eumenidae), Dr. R. Wahis (Pompilidae), Dr. M. Ohl (Sphecidae), Dr. K. Horstmann (Ichneumonidae), O. Niehuis (Chrysididae), Dr. D.B. Baker (Apidae) und Dr. P. Hartmann für Ratschläge zur sicheren Bienendetermination.

Bei allen MitarbeiterInnen des Fachgebietes Agrarökologie, insbesondere bei Hella Grabe, Susanne Jahn und Susanne Schiele, bedanke ich mich für die nette Arbeitsatmosphäre und die Hilfsbereitschaft in jeder Hinsicht. Joachim Kuhnhenne und Friedrich Sundmacher danke ich für jegliche und stets schnelle Hilfe am Computer. Besonderer Dank gilt auch meinem 
Zimmerkollegen Jochen Krauss für ein gutes Zusammen- und Nebeneinanderarbeiten und die zahlreichen Diskussionen und Antworten auf viele Fragen.

Meinem Freund Christian Erle danke ich für die große Hilfe und Unterstützung während der gesamten Promotionszeit, besonders für die viele Zeit die er mit unserem Sohn Jona verbracht hat, wenn ich doch etwas länger am Schreibtisch saß. Jona danke ich für sehr schöne, abwechslungsreiche, wenn auch manchmal anstrengende Pausen. Die eine oder andere Nacht hätte ich allerdings doch lieber geschlafen!

Vielen Dank für das Korrekturlesen an Christian, Erika, Günter und Volker.

Ein herzliches Dankeschön gilt meiner Mutter und Christians Eltern, die immer bereit waren Jona zu betreuen, wenn es mit der Zeit eng war. Schließlich möchte ich allen meinen Freundinnen und Freunden danken, die mir in diesen drei Jahren beiseite standen.

An Euch alle ein herzliches Dankeschön für die schöne Zeit. 


\section{Lebenslauf}

Alexandra-Maria Klein

am 17.09.1972 in Göttingen geboren

Seit 01/2000 Dissertation im Fachgebiet Agrarökologie, angegliedert an den SFB 552 ,Prozesse der Destabilisierung und Bedingungen der Stabilität von Randzonen tropischer Regenwälder in Indonesien'. Prüfungen im Mai 2003 in dem Hauptfach Agrarökologie und den Nebenfächern Zoologie und Agrarentomologie.

10/98-11/99 Diplomarbeit im Fachgebiet Agrarökologie zum Thema ,Die Folgen der Landnutzung im Randbereich tropischer Regenwälder Indonesiens für die Pflanze-Insekt-Lebensgemeinschaften’

04/95-03/00 Studentische, später wissenschaftliche Hilfskraft an der Georg-AugustUniversität Göttingen im Albrecht-von-Haller-Institut für Pflanzenwissenschaften.

10/93-11/99 Diplom-Studium der Biologie an der Georg-August-Universität Göttingen. Diplomprüfungen im Hauptfach Botanik, Nebenfächer tropischer und subtropischer Pflanzenbau und Naturschutz. Drei Monate Praktikum in Brasilien auf der ökologischen Farm von Dr. José Lutzenberger.

1993 Abschluss der Allgemeinen Hochschulreife in Göttingen

\section{Sprachen}

Deutsch (Muttersprache)

Englisch, Indonesisch (fließend)

Französisch, Portugiesisch, Spanisch (gute Kenntnisse) 